PNNL-10956

\title{
Technical Evaluation of Proposed Ukrainian Central Radioactive Waste Processing Facility
}

June 1996

Prepared for

the U. S. Department of Energy

Office of Nuclear Energy, Science and Technology

Under the International Nuclear Safety Program

by

Robert Gates

Andrei Glukhov

Franz Markowski

Pacific Northwest National Laboratory

Richland, Washington 99352 


\title{
DISCLAIMER
}

This report was prepared as an account of work sponsored by an agency of the United States Government. Neither the United States Government nor any agency thereof, nor Battelle Memorial Institute, nor any of their employees, makes any warranty, express or implied, or assumes any legal liability or responsibility for the accuracy, completeness, or usefulness of any information, apparatus, product, or process disclosed, or represents that its use would not infringe privately owned rights. Reference herein to any specific commercial product, process, or service by trade name, trademark, manufacturer, or otherwise does not necessarily constitute or imply its endorsement, recommendation, or favoring by the United States Government or any agency thereof. or Battelle Memorial Institute. The views and opinions of authors expressed herein do not necessarily state or reflect those of the United States Government or any agency thereof.

\author{
PACIFIC NORTHWEST NATIONAL LABORATORY \\ operated by \\ BATTELLE \\ for the \\ UNITED STATES DEPARTMENT OF ENERGY \\ under Contract DE-AC06-76RLO 1830
}

This document was printed on recycled paper

Technical Evaluation of Proposed Ukrainian Radioactive Waste Processing Facility 



\section{Summary}

This technical report is a comprehensive evaluation of the proposal by the Ukrainian State Committee on Nuclear Power Utilization (Goskomatom) to create a central facility for radioactive waste (not spent fuel) processing. The central facility, as proposed by Goskomatom, is intended to process liquid and solid radioactive wastes generated from all of the Ukrainian nuclear power plants and the waste generated as a result of Chomobyl 1,2 and 3 decommissioning efforts. In addition, this report provides general information on the quantity and total activity of radioactive waste in the 30-km Zone and the Sarcophagus from the Chomobyl accident. Because of the large quantities of radioactive waste located within the $30-\mathrm{km}$ Zone and the Sarcophagus and the uncertainties surrounding the exact inventories involved, it is unrealistic at this time to develop fully detailed plans for the facilities required for final long-term disposal of 30-km Zone and Sarcophagus wastes. This is a unique problem that will require more study than a short technical assessment of a proposed central facility allows. However, processing options are described that may ultimately be used in the long-term disposal of selected 30-km Zone and Sarcophagus wastes.

This report presents a compilation of referenced estimates for radioactive waste volumes resulting from operations, decommissioning, and wastes within the 30-km Zone and the Sarcophagus. These references are published reports from both Western experts and experts from Ukraine and the Former Soviet Union. A detailed report on the issues concerning the construction of a Ukrainian Central Radioactive Waste Processing Facility (CRWPF) from the Ukrainian Scientific Research and Design Institute for Industrial Technology was obtained and incorporated into this report. It should be recognized that the situation surrounding NPP decommissioning, wastes within the 30-km Zone and within the Sarcophagus itself, is a complex problem that has been subject to the social and economic forces currently playing out within Ukraine and the Former Soviet Union. Some references will tend to overestimate radioactive waste volumes and others tend to under estimate waste volumes for a number of various competing reasons. Accurate and complete knowledge of the Sarcophagus conditions have been hindered not only by purely physical restrictions, but also by bureaucratic tangles, leaving the experts involved to speculate. For these reasons, among others, reported waste volumes for continuing operations, decommissioning, and wastes within the 30-Zone and the Sarcophagus will at times diverge from other estimates by several orders of magnitude. Presenting opportunities for further detailed research where current knowledge is not complete

This report outlines various processing options, their associated costs and construction schedules, which can be applied to solving the operating and decommissioning radioactive waste management problems in Ukraine. The costs and schedules are best estimates based upon the most current U.S. industry practice and vendor information. It is recognized that the Ukrainian regulatory structure, utility structure and overall economic situation will present unique challenges

Technical Evaluation of Proposed Ukrainian Radioactive Waste Processing Facility 
and uncertainties which may extend the schedule significantly. For example, one radioactive waste equipment vendor working in Russia reported a two year negotiating period necessary to securing a contract that will require only eleven months for completion.

Goskomatom reports there are no industries within Ukraine that currently design and build radioactive waste processing equipment. This report, for purposes of developing the cost estimates, assumes foreign vendors will design and supply the capital equipment necessary for the radioactive waste processing trains. The development of a Ukrainian infrastructure capable of safely handling and disposing of radioactive waste is important and should be developed in concert with the design of the equipment used to process the radioactive waste. Delivery of equipment alone would be inadequate if there is no infrastructure to support safe and efficient operation of the systems.

This report compares the options using a method which estimates the total present worth (in terms of cost). The total present worth includes the capital equipment costs, facilities costs and the yearly operating costs of processing and storing the wastes. The option with the lowest total present worth (least cost option) is chosen as the preferred altemative. The operating costs are generated using U.S. information for equipment and labor rates. There was no information provided on Ukrainian labor rates so Ukrainian operational costs could not be estimated. Total Ukrainian operational costs will definitely be significantly less due to the fact that the corresponding hourly average rates under Ukrainian conditions are significantly less. However, because a comparative method was used in the selection of the preferred altemative the least cost option remains the same

The least cost option would use proven, innovative state-of-the-art, skid mounted or mobile technology to perform primary waste treatment and volume reduction at the individual waste producing sites. Advanced volume reduction techniques have been developed that allow for a reduction of waste volumes by approximately a factor of four or more depending upon the process chosen. This strategy reduces the total volumes that would have to be processed and stored at a central facility to be located at the Chomobyl site. The central facility would process the concentrated liquids and resins using solidification trains and would process the solids using supercompaction. The central facility processing trains would package the wastes in containers that meet the criteria for final disposal in a suitable near surface disposal facility. Only those wastes that meet Ukrainian established classification criteria should be disposed of in near surface disposal facilities. Those wastes with radio nuclide concentrations that exceed the classification criteria would be placed into safe interim storage until long term disposal in a geologic repository could be achieved. Proven technology for near surface disposal facilities in order of increasing cost are: shallow land disposal, below ground vaults, earth mounded concrete bunkers, and above ground vaults. Ukrainian plans and proposais for a long term geologic repository are outside the scope of this report and are not discussed

Technical Evaluation of Proposed Ukrainian Radioactive Waste Processing Facility 
The table below summarizes the cost estimates based upon the U.S. generic cost estimates for the processing and disposal of radioactive wastes contained in Reference [11]. These costs are also based on vendor supplied capital cost information for typical systems and components that would be used in a central radioactive waste processing facility. The least cost option was chosen based upon the total present worth including capital equipment costs, facilities costs, processing/operating costs, and storage costs. Using a conventional approach without advanced volume reduction techniques results in total costs that are significantly higher. This is because a conventional approach results in greater volumes of waste to process and store. Additional information on the details and assumptions behind the cost estimates and capital investment schedules developed independently by participating Ukrainian Institutes are contained in the body of the report.

\begin{tabular}{|l|c|c|}
\hline \multicolumn{2}{|c|}{ Least Cost Option - Capital Equipment Estimate Summary, (U.S. \$) } \\
\hline \multicolumn{1}{|c|}{ Process Description } & Low Range & High Range \\
\hline Single Solids Compactor System & $\$ 74,000$ & $\$ 295,000$ \\
\hline $\begin{array}{l}\text { Central Compactor for all NPPs and CNPP } \\
\text { D\&D waste. }\end{array}$ & $\$ 640,000$ & $\$ 2,560,000$ \\
\hline $\begin{array}{l}\text { Single Advanced Mobile } \\
\text { Process/Evaporator Unit }\end{array}$ & $\$ 5,900,000$ & $\$ 13,300,000$ \\
\hline $\begin{array}{l}\text { Three Advanced Mobile Process/Evaporator } \\
\text { Units }\end{array}$ & $\$ 17,700,000$ & $\$ 39,900,000$ \\
\hline Single Solidification Train & $\$ 1,000,000$ & $\$ 6,000,000$ \\
\hline $\begin{array}{l}\text { Central Solidification Train Processing all } \\
\text { NPPs and CNPP Operating Wastes }\end{array}$ & $\$ 1,500,000$ & $\$ 8,900,000$ \\
\hline $\begin{array}{l}\text { Storage Facility for all NPPs and CNPP } \\
\text { Solidified Liquids and Resins }\end{array}$ & $\$ 9,900,000$ & unavailable \\
\hline $\begin{array}{l}\text { Storage Facility for all NPPs and CNPP } \\
\text { Compacted Solids }\end{array}$ & $\$ 71,100,000$ & unavailable \\
\hline Storage Facility for 3 RBMKs D\&D Waste & $\$ 73,700,000$ & unavailable \\
\hline
\end{tabular}

Technical Evaluation of Proposed Ukrainian Radioactive Waste Processing Facility 


\section{Acknowledgments}

Major contributions and support in the development of this technical report was provided by Victor D. Chebrov, Chairman of Goskomatom, and C. Faschevsky, Director Ukrainian Central Radioactive Waste Processing Facility. Special thanks are also due to the contributing directors, engineers and specialists at participating Ukrainian Institutes including: G.A. Maslyakov, V.M. Zeinichenko and V.N. Pukhalskiy. Acknowledgments also go to Pacific Northwest National Laboratory (PNNL) contributors Pierce Ostrander who provided financial details, and Don Bradley who provided information and direction on the most current radioactive waste data available for Soviet-Designed Reactors.

Technical Evaluation of Proposed Ukrainian Radioactive Waste Processing Facility 


\section{Contents}

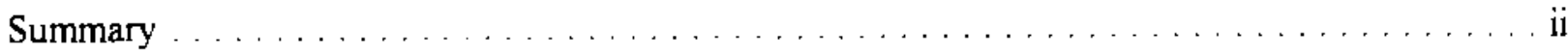

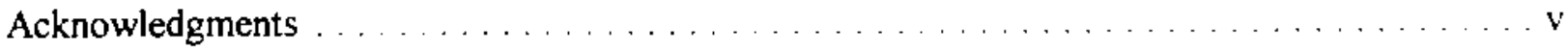

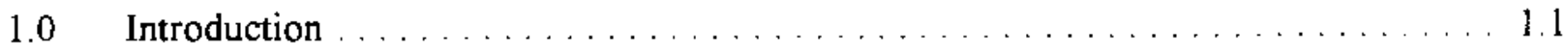

$2.0 \quad$ Volumes and Generation Rates of Radioactive Wastes . . . . . . . . . . . . . 2.1

$2.1 \quad$ Radioactive Waste Information for Soviet Designed Reactors . . . . . . . . 2. 1

2.2 Typical Radioactive Waste Information for Western Plants Including U.S. PWRs

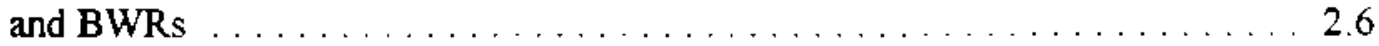

$2.3 \quad$ Radioactive Waste Information Presented by Ukrainian Institutes . . . . . . . $\quad 2.9$

2.3.1 Radioactive Waste Information Presented by Goskomatom ....... 2.10

2.3.2 Radioactive Waste Information Presented by Ukrainian Scientific Research

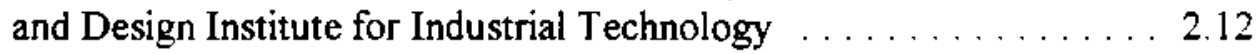

2.3.3 Radioactive Waste Information Provided by the Ukrainian Ministry of

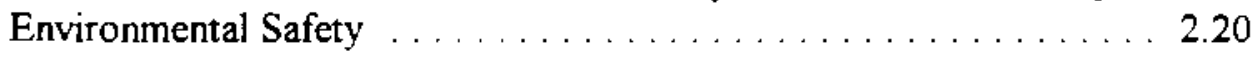

2.4 Wastes Located Within $30-\mathrm{km}$ Zone and the Unit 4 Sarcophagus $\ldots \ldots \ldots 2.22$

3.0 Options Available for Solution of Ukrainian Radioactive Waste Problem . . . . . . 3.1

$3.1 \quad$ Ukrainian Design Information for Proposed Central Facility . . . . . . . . . 3.2

3.1.1 Ukrainian Cost Estimates for the Goskomatom Proposal . . . . . . . . 3.3

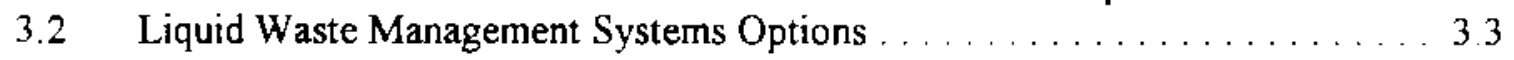

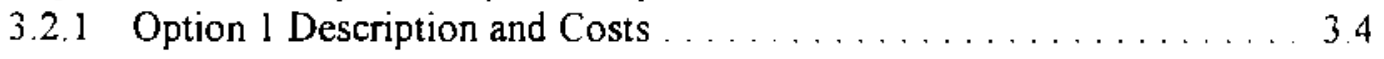

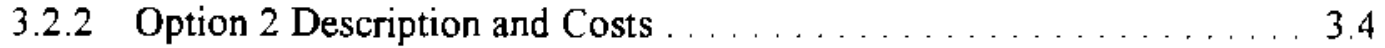

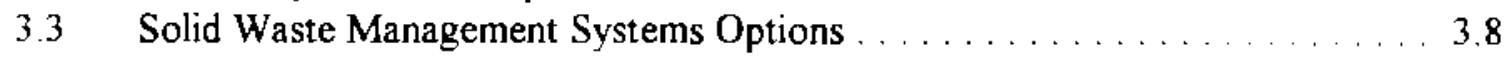

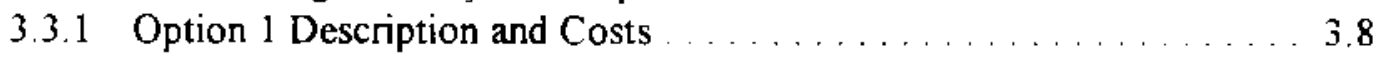

3.3.2 Option 2 Description and Costs . . . . . . . . . . . . . . . . 3.9

3.3.3 Option 3 Description and Costs . . . . . . . . . . . . . . . 3.9

3.4 Options for Storage Facility and Central Shielded Process Building . . . . 3. 3.10

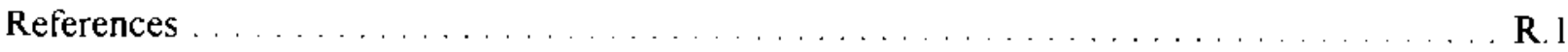

Appendix A: Computer Models used in this Evaluation (Radstat l.xls and Ukrcalc1.mcd) . . A.1

Appendix B: Figures Showing Typical Treatment Methods and Processes . . . . . . . . B.1

Appendix C: Classification of Radioactive Waste in the Former USSR .......... C.I

Appendix D: Questions Submitted to GOSKOMATOM Regarding the Proposed Facility ... D.1

Technical Evaluation of Proposed Ukrainian Radioactive Waste Processing Facility 


\section{Tables}

1 - Annual Radioactive Waste Generation by Reactor Type and (5 Year Estimates) 2.2

2 - Solid Wastes Generated from Reactor Decommissioning $\quad 2.4$

3 - Storage Capacities for Radioactive Waste at Russian Designed NPPs 2.6

4 - U.S. Normalized Radioactive Waste Generation Rates $\quad 2.7$

5 - Total Unprocessed Liquid Radioactive Waste Inputs for U.S. NPPs 2.8

6 - Ukrainian Liquid Waste Storage Tank Capacities $\mathrm{m}^{3}$

7 - Ukrainian Solid Waste Classifications

8 - Ukrainian Capital Equipment Cost Estimate $\quad 2.13$

9 - Quantity of Liquid Radwaste by Nuclear Power Plant, $\mathrm{m}^{3} \quad 2.15$

$\begin{array}{ll}10 \text { - Composition of Solid Radioactive Waste } & 2.17\end{array}$

11 - Volume of Solid Radwaste by Nuclear Power Plant and Design Storage Capacity, $\mathrm{m}^{3} \quad 2.18$

12 - Solid Radwaste Samples from the Reactor Hall of Unit No. 4, Zaporozhye 2.19

13 - Least Cost Option \#2 - Capital Equipment Estimate Summary 3.6

\section{Figures}

2.1 - Forecasts for Ukrainian Liquid Waste Volumes and Storage Capacities 2.25

2.2 - Forecasts for Ukrainian Solid Waste Volumes and Storage Capacities 2.26

2.3 - Estimated 30 yr Operations and Decommissioning Total Waste Volumes by $\begin{array}{ll}\text { Year of Plant Shutdown } & 2.27\end{array}$

2.4 - Distribution of Waste Forms, Totais for All Ukrainian NPPs, Not Including the Sarcophagus or $30 \mathrm{~km}$ Zone Wastes

Technical Evaluation of Proposed Ukrainian Radioactive Waste Processing Facility 



\subsection{Introduction}

The Ukrainian State Committee on Nuclear Power Utilization (Goskomatom) is proposing to create a central radioactive waste processing facility. Goskomatom has approached the U.S. Department of Energy (DOE) Office of Nuclear Energy, Science and Technology requesting cooperation on a project to create a central facility for radioactive waste processing to be located outside the site boundary at the Chernobyl Nuclear Power Plant (NPP) site. The DOE Office of Nuclear Energy, Science and Technology directed PNNL, under the International Nuclear Safety Program, to complete a technical evaluation of the Ukrainian proposal within the framework of addressing safe operation and decommissioning issues associated with the Chemobyl NPP Ref. [1]. This technical report was prepared in cooperation with Ukrainian technical experts so as to accurately reflect the best technical information available and to accurately reflect the views of Goskomatom, the Ukrainian National Academy of Sciences, participating Ukrainian Institutes, as well as PNNL technical experts.

There are eleven VVER-1000, two VVER-440 and two RBMK-1000 power plants currently operating in Ukraine. This report includes referenced estimates for the generation and current inventories of radioactive waste from the following sources: currently operating plants, decommissioning of the 3 RBMK- 1000 plants at Chornobyl, decommissioning of the two VVER440 plants, decommissioning of the eleven VVER-1000 plants, waste inventories in the $30-\mathrm{km}$ Zone, and estimates for volumes of radioactive waste located inside the destroyed Chomobyl unit 4 Sarcophagus.

Not all of the referenced estimates for radioactive waste inventories within the $30-\mathrm{km}$ Zone and within the unit 4 Sarcophagus are included in the evaluation of the central facility. It is certain that waste types such as: contaminated ground, vegetation, forests, cooling pond silt and highlevel Sarcophagus wastes will not be processed in such a facility. It is more likely that the wastes, depending upon their category, will be either left in current storage, immobilized in situ or will be transferred from the approximately 600 to 800 interim storage trenches to long term engineered near surface disposal facilities or transferred to interim storage prior to disposal in a future deep geologic repository.

In addition, shutdown of the first VVER plant is not scheduled until 2007 and VVER decommissioning work will continue through 2025 indicating a staggered approach to siting the necessary processing capabilities may be appropriate. For this reason the central facility should be designed with the ability to expand its capability rather than designing the facility for the total decommissioning waste produced through 2025 . However, the total capacity required for the near surface disposal facilities should factor in the total volume of waste that will be produced.

This evaluation does not address spent fuel or RBMK reactor graphite as these issues are being

Technical Evaluation of Proposed Ukrainian Radioactive Waste Processing Facility 
addressed through other means. This report focuses primarily on the handling and processing of what is defined in the U.S. as low-level radioactive wastes. 



\subsection{Volumes and Generation Rates of Radioactive Wastes}

Central to the technical evaluation of the proposed radioactive waste processing facility is the ability to quantify the volumes and generation rates of the liquid and solid radioactive wastes produced by the Ukrainian NPPs. The characteristics of radioactive waste from NPP operation can be dependent upon several diverse factors which are not easily defined or standardized. This is particularly true with the Ukrainian NPPs where limited data on radioactive waste stream characteristics is available. Data on annual radioactive waste generation rates and volumes by Soviet designed reactor type was obtained from Ref. [5] and is presented in Table 1. Typical Russian storage space data presented in Table 3 was also obtained from Refs. [7 \& 8]. In addition, reasonable estimates can be made and documented by drawing upon "typical" radioactive waste data that is available from operating experience of U.S. Pressurized Water Reactors (PWRs) and Boiling Water Reactors (BWRs) Refs. [2-4]. The U.S. "Typical" data is presented in Tables 4 and 5. The data from Refs. [5, $7 \& 8$ ] and the U.S. NPPs will be used as a basis for comparison with the Ukrainian data from Goskomatom and other Ukrainian Institutes. The data provided by Goskomatom is presented in Section 2.3. Estimates of radioactive waste volumes generated over a five year period are shown in parentheses to allow for comparison with the volumes generated since Ukrainian independence in 1991. Figures 2.1 and 2.2 provide estimated forecasts for Ukrainian liquid and solid waste volumes and storage capacities.

\subsection{Radioactive Waste Information for Soviet Designed Reactors}

At Russian designed NPPs, liquid waste is processed and classified as follows: evaporator bottoms, low-level sorbents, high-level sorbents and perlite (RBMK-1000 reactors only) Ref. [5]. The data on waste type, annual quantities generated and historical volumes generated from 30 years of NPP operation is presented in Table 1. Data on unprocessed liquid radioactive waste streams was not available. The classification of radioactive wastes in the former USSR is detailed in Appendix C.

The solid radioactive waste at Russian designed reactors is pre-treated at the NPP site and consists of the following steps. Ref. [5]: waste collection and sorting by contamination groups and treatment possibilities, waste transportation to a storage area or to a processing facility, incineration of solid organic waste and incorporation of the ash into cement, compaction of solid noncombustible wastes, scrap decontamination, and finally, storage in a repository. High-level wastes are planned to be packed into containers and casks and then solidified with cement. Graphite waste materials are stated as being hard to process and are apparently handled using special composites. Metal decommissioning wastes were recommended to be decontaminated and compacted.

Technical Evaluation of Proposed Ukrainian Radioactive Waste Processing Facility 


\section{Table 1}

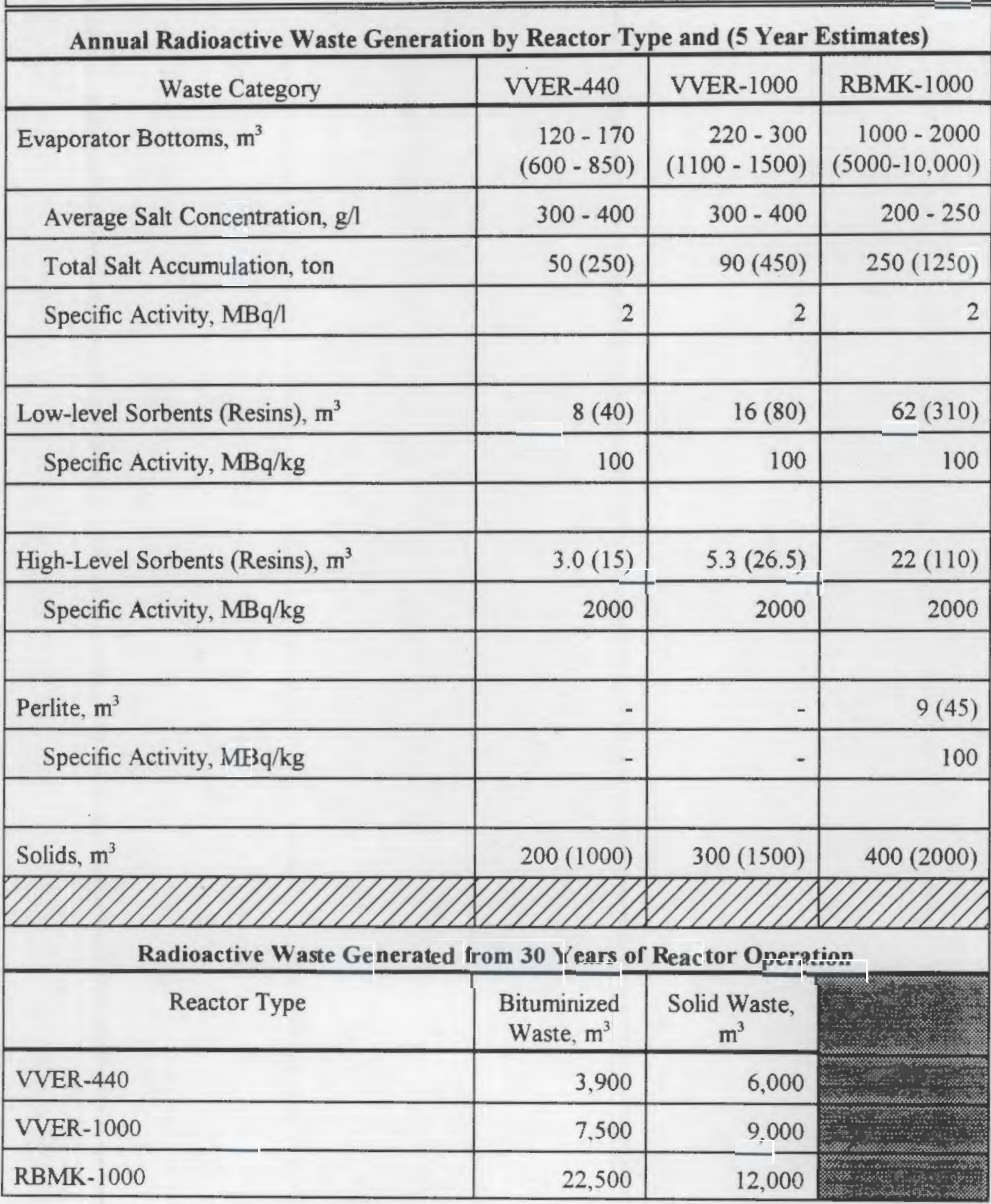

Technical Evaluation of Proposed Ukrainian Radioactive Waste Processing Facility 
Reference [6] describes radioactive waste management in Russia as follows, "The radioactive waste produced in NPPs belongs to the class of low and medium level waste (high level waste accounts for less than 1\%). All types of radioactive waste are stored on the territory of the NPP. Liquid radioactive waste is stored in concentrated form after evaporation. Solid radioactive waste is not processed and is placed in special concrete structures. The amount of liquid and solid radioactive waste produced annually is approximately equal to the design values."

Reference [14] describes the radioactive waste handling process at the Zaporozhye VVER-1000 NPP as follows:

1. Radioactive wastes are transported in special shielded vehicles, from reactors to a decontamination shop located nearby, where the wastes are sorted.

2. Combustible wastes are bumed in a "special furnace" at a temperature of 1,100 ${ }^{\circ} \mathrm{C}$, and the off-gases are "cleaned" and monitored.

3. Metals are compacted and packed in shielded carbon steel drums reducing their volume by 4 to 100 times. The drums are then lowered into "wells" inside a storage facility for radioactive wastes. These storage wells are set in concrete and covered with concrete lids 900 to $1200 \mathrm{~mm}$ thick, weighing from 1.0 to 4.5 tons and are periodically monitored. The three storage facilities at Zaporozhye are stated to be capable of storing all wastes produced over the plant lifetime.

It should be noted that Goskomatom made no mention of an incineration facility at Zaporozhye when questions were submitted regarding current processing capabilities at the operating NPP sites. Therefore, it is not clear that the incineration facility described by Ref. [14] is currently in an operating condition.

The organizations within the Former Soviet Union (FSU) and foreign companies involved in designing radioactive waste processing equipment for the FSU are listed in Refs. [5 \& 15] they are: Research Institute for Nuclear Power Plant Operation (VNIIAES), Radon. Scientific Production Association, Design and Research Institute of Complex Power Technology (VNIPIET), Scientific Research Institute of Chemical Machine Building (SNHM). NUKEM (a German company), and Chem-Nuclear Systems (an American company). NUKEM constructed a facility at the Balakovo site with $25 \%$ of the components manufactured in Russia with plans for similar equipment to be installed at other sites within Russia. Chem-Nuclear is building a liquid radioactive waste processing system to be installed in August of 1996 on a barge in Vladivostok and has plans for similar facilities for the Russian Northern fleet as well as the Black Sea fleet.

Technical Evaluation of Proposed Ukrainian Radioactive Waste Processing Facility 
Reference [5 \& 18] provide data on the expected amounts of solid wastes that will be generated during reactor disassembly and decommissioning. In addition to the primary decommissioning wastes shown in Table 2, secondary wastes generated as a result of decommissioning activities is estimated as 10 to $15 \%$ of that shown in Table 1 for radioactive waste generated from 30 years of operation. It has been noted that these referenced estimates provided by Russian organizations are not as comprehensive and detailed as typical western estimates such as those contained in Reference [28].

\begin{tabular}{|l|c|c|c|}
\hline \multicolumn{3}{|c|}{ Table 2 } \\
\hline \multicolumn{3}{|c|}{ Solid Wastes Generated from Reactor Decommissioning } \\
\hline Reactor Type & Concrete, tons & Scrap, tons & Equipment, tons \\
\hline VVER-440 & 9,000 & 500 & 4,000 \\
\hline VVER-1000 & 12,000 & 900 & 6,000 \\
\hline RBMK-1000 & 36,000 & 2,500 & 15,000 \\
\hline
\end{tabular}

Reference [18] provides detailed estimates for disassembly of the equipment for an RBMK-1000 reactor. This data was generated to support a decommissioning study for the Kursk NPP in Russia. The estimate for metallic equipment wastes from disassembly of a single unit was reported at approximately 20.752 tons. This total was also broken down into the following categories:

High-Level (Group III)

Medium \& Intermediate-Level (Group II) Low-Level (Group I)

No Thorough Decontamination Required Total
1.5 tons

$2,576.5$ tons

$9,528.0$ tons

$8,646.0$ tons

20,752 tons

Reference [18] indicated that the volume of waste that did not require thorough decontamination would be free released and recycled leaving 12,106.0 tons of equipment as radioactive wastes

Reference [18] also provided additional estimates for wastes produced during decommissioning of a VVER-440 reactor. This data was generated to support a decommissioning study for the Novovoronezh NPP in Russia. The estimate for equipment waste from disassembly of a single unit for long-term observed observation was reported at approximately 22,280 tons. The total solid wastes generated as a result of disassembly of equipment and structures for a dual unit VVER-440 piant during the third phase of decommissioning were reported as follows:

Technical Evaluation of Proposed Ukrainian Radioactive Waste Processing Facility 
1. Metallic Wastes

Equipment from Primary Loop

Metallic Equipment and Structural Elements

Non-Radioactive Equipment

\section{Non-Metallic Wastes}

Radioactive Solid Wastes (plaster, concrete, etc.)

Non-Radioactive Solid Wastes

Total Radioactive (Two VVER-440s)

Total Non-Radioactive (Two VVER-440s)
3,370 tons

6,000 tons

35,000 tons

The quantity of solidified liquid radioactive waste accumulated during 30 years of operation of a VVER-440 design were reported by Reference [18] to be $5,200 \mathrm{~m}^{3}$ per unit. The quantity of solid radioactive waste accumulated during 30 years of operation were reported by Reference [18] to be $6,000 \mathrm{~m}^{3}$ per unit. The quantity of solidified liquid and solid radioactive wastes produced during decommissioning were estimated at $10 \%$ of the quantities formed during operation.

It should be noted and in fact is highly recognized that the estimates for the amounts of radioactive waste generated during decommissioning vary considerably, ranging for a typical NPP from as low as 3000 tons in some countries to the maximum of 53,500 tons for the RBMK-1000. The decommissioning strategy and the methods that will be used to segregate the fraction of material that will be released for restricted or unrestricted use have a large impact on the estimates. 
Data on available radioactive waste storage capacities for Russian designed NPPs was obtained from Refs. [ $7 \& 8$ ]. The data on radioactive waste storage capacity was normalized to $\mathrm{m}^{3}$ per MWe installed capacity for purposes of comparison with the Ukrainian data.

\begin{tabular}{|c|c|c|c|}
\hline \multicolumn{4}{|c|}{ Table 3} \\
\hline \multicolumn{4}{|c|}{ Storage Capacities for Radioactive Waste at Russian Designed NPPs } \\
\hline NPP Facility & Storage Type & $\begin{array}{l}\text { Capacity, } \mathrm{m}^{3} \\
\text { and Used } \\
\text { Capacity }(\%)\end{array}$ & $\begin{array}{l}\text { Normalized } \\
\text { Capacity, } \\
\mathrm{m}^{3} / \mathrm{MWe}\end{array}$ \\
\hline \multirow{3}{*}{$\begin{array}{l}\text { Kola Site }^{(a)} \\
4 \text { VVER-440s } \\
\text { 1760 MWe }\end{array}$} & Two Liquid Storage Blocks & $7326(77 \%)$ & 4.2 \\
\hline & Two Solid Storage Blocks & $7475(27 \%)$ & 4.2 \\
\hline & Solid Low-Level Waste & $12,060(30 \%)$ & 6.8 \\
\hline \multirow{2}{*}{$\begin{array}{l}\text { Kalinin Site }{ }^{(b)} \\
2 \text { VVER-1000s } \\
2000 \text { MWe }\end{array}$} & Liquid Storage LLW \& II.W & $3617(94 \%)$ & 1.8 \\
\hline & Solid Storage LLW \& ILW & $5000(13 \%)$ & 2.5 \\
\hline \multirow{2}{*}{$\begin{array}{l}\text { Balakovo Site } \\
4 \text { VVER-1000s } \\
4000 \mathrm{MWe}\end{array}$} & Liquid Storage LLW \& ILW & $3797(79 \%)$ & 0.9 \\
\hline & Solid Storage LLW \& ILW & $6000(30 \%)$ & 1.5 \\
\hline \multirow{2}{*}{$\begin{array}{l}\text { Smolensk Site }{ }^{(b)} \\
3 \text { RBMK-1000s } \\
3000 \mathrm{MWe}\end{array}$} & Liquid Storage LLW \& ILW & $11,746(63 \%)$ & 3.9 \\
\hline & Solid Storage LLW \& ILW & $19,697(33 \%)$ & 6.6 \\
\hline
\end{tabular}

(a) Ref. [7] - 1994 data

(b) Ref [8] - 1992 data

\subsection{Typical Radioactive Waste Information for Western Plants Including U.S. PWRs and BWRs}

Reference [3] reports the radioactive waste volumes and generation rates in values that were taken from operating data and normalized to one GW(e) installed power. Using this information, projections can be made of the annual radioactive waste generation rates and the total volumes generated over an extended period. The principal waste streams for a U.S. PWR and BWR are presented in Table 4 in normalized values. In addition, for 1000 MWe PWRs and BWRs Table 4 provides values for annual and 5 years of operation. Note that in the U.S. high-level waste is defined as spent fuel and wastes from fuel reprocessing, therefore, all waste categories in Table 4 are defined as Low-Level waste

Technical Evaluation of Proposed Ukrainian Radioactive Waste Processing Facility 


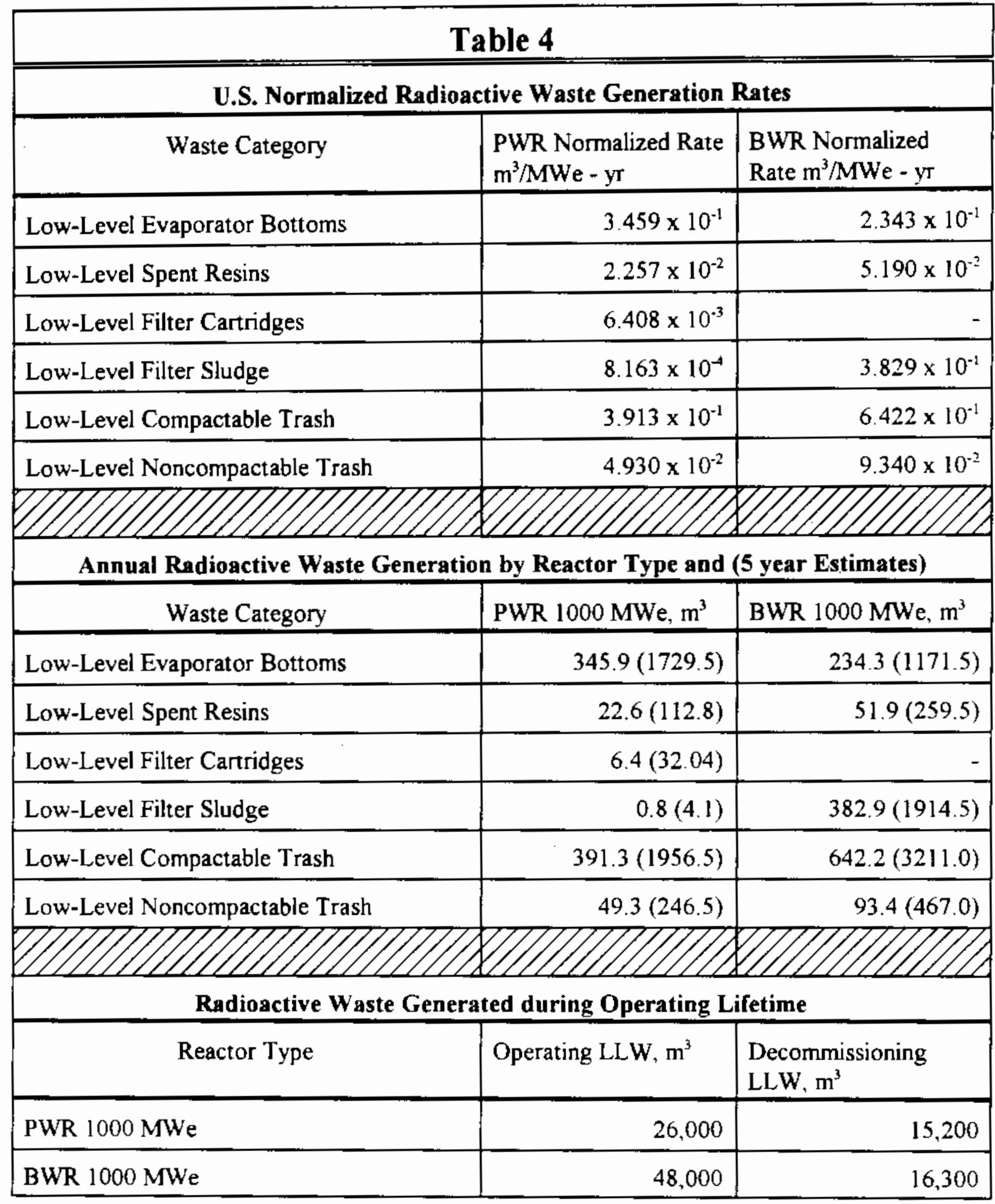

Technical Evaluation of Proposed Ukrainian Radioactive Waste Processing Facility 
The probable quantities of unprocessed liquid radioactive waste for representative U.S. BWR and PWR plants are found in Ref. [9]. These quantities of unprocessed wastes are considered representative of the inputs to a U.S. NPP radioactive waste processing system. The details for each individual NPP radioactive waste stream are important for assigning one of several possible processing methods or treatment combinations. There are no standard processes or treatment methods in the U.S. Commercial vendors in the U.S. are capable of competitively supplying a number of different proprietary processes that can be applied to similar waste stream inputs. However, a basic process that is representative of the functional process steps can be developed and evaluated against the Ukrainian proposal. The functional process steps must be capable of processing the expected average daily inputs and the inputs from a conservatively chosen design basis event. Table 5 presents a summary of the total unprocessed waste inputs for the expected average daily input and the input from a conservatively chosen design basis event Ref. [9].

\begin{tabular}{|l|l|l|}
\hline \multicolumn{2}{|c|}{ Table 5 } \\
\hline \hline \multicolumn{2}{|c|}{ Total Unprocessed Liquid Radioactive Waste Inputs for U.S. NPPs } \\
\hline Reactor Type & $\begin{array}{l}\text { Expected Generation Rate, } \\
\text { gal/day }\end{array}$ & $\begin{array}{l}\text { Design Basis Event Max } \\
\text { Generation Rate, gal/day }\end{array}$ \\
\hline BWR 1000 MWe & 38,340 & 165,160 for 1 day \\
\hline PWR 1000 MWe & 44,090 & 61,200 \\
\hline
\end{tabular}

In the U.S., the Nuclear Regulatory Commission (NRC) under Reference [19] sets forth the regulations for classification of radioactive waste for near surface disposal. Reference [19] describes the two considerations involved in the classification of radioactive waste. First, consideration is given to the concentration of long-lived radio nuclides whose potential hazards persist long after precautions such as institutional controls, waste forms, and deeper disposal have ceased to be effective. Second, consideration is given to the concentration of shorter-lived radio nuclides for which requirements on institutional controls, waste form and disposal method are effective. Waste is classified using specific radio nuclide concentration limitations into Class A, B, and $C$ waste. If the concentration exceeds the values listed below the wastes are not generally acceptable for near-surface disposal in the U.S., Ref. [19]

Radio nuclide Concentration $\mathrm{Ci} / \mathrm{m}^{3}$

Long Lived Radio nuclides:

C-14 8

C. 14 in activated metal 80

$\mathrm{Ni}-59$ in activated metal 220

Technical Evaluation of Proposed Ukrainian Radioactive Waste Processing Facility 
Long Lived Radio nuclides: cont.

$\mathrm{Nb}-94$ in activated metal

Tc-99

I-129

Alpha emitting transuranic nuclides with half lives $>5 \mathrm{yrs}$.

Pu-241

$\mathrm{Cm}-242$
0.2

3

0.08

$100^{(1)}$

$3,500^{(1)}$

$20,000^{(1)}$

Short Lived Radio nuclides:

Total of all nuclides with half lives $<5 \mathrm{yrs}$

$700^{(2)}$

H-3

$40^{(2)}$

Co-60

$700^{(2)}$

Ni-63

700

Ni-63 in activated metal

7000

$\mathrm{Sr}-90$

7000

Cs- 137

4600

Notes:

(1) units are nanocuries per gram.

(2) This is a Class A limit, there are no concentration limits on these radio nuclides for near surface disposal. Practical considerations such as dose rate at the package surface and handling restrictions will limit the concentration of these radio nuclides.

Additional requirements and special considerations for Class A, B and C waste such as stability, institutional controls and characteristics are contained in Reference [19] and for purposes of brevity will not be addressed here.

\subsection{Radioactive Waste Information Presented by Ukrainian Institutes}

In the process of evaluating the Ukrainian proposal to build a central radioactive waste processing facility, detailed questions (see Appendix D) were submitted to Victor D. Chebrov, Chairman of Goskomatom and C. Faschevsky, Director Ukrainian Central Radioactive Waste Processing Facility. Goskomatom also coordinated its efforts with the Ukrainian Scientific Research and Design Institute for Industrial Technology and the Ukrainian National Academy of Sciences. 


\subsubsection{Radioactive Waste Information Presented by Goskomatom}

Initial responses to the questions PNNL submitted are contained in Ref. [16]; a Letter from Goskomatom to PNNL. The letter contained the following information:

1. At the present time, the work related to creation of the Central Radioactive Waste Processing Facility (CRWPF) are in a stage of agreement on feasibility studies for site selection and performance of construction works.

2. The Ministry of Environmental Protection and Nuclear Safety is the regulatory body in Ukraine responsible for obtaining permits (licenses) to build and operate the CRWPF, as well as to transport radioactive waste. The regulatory document are the Laws of Ukraine entitled, "On using Nuclear Power and Radiation Safety" and "On Radioactive Waste Treatment."

3. In accordance with the general scheme of development of a radioactive waste processing industry in Ukraine, issued by Goskomatom, it is suggested that liquid radioactive waste from all Nuclear Power Plants in Ukraine would be transported to the CRWPF. Liquid radioactive waste can be transported only after preliminary processing at an evaporator, bituminization, or cementation installation, where liquid waste is transferred to a solid crystal matrix and placed into 200 liter drums, the drums are then loaded into special containers for transport to the CRWPF.

4. During decommissioning of the Chernobyl NPP all kinds of radioactive waste will be generated out of which only low-level and intermediate-level radioactive waste (both liquids and solids) will be processed.

5. Liquid radioactive wastes are classified as:

Low-Level (specific activity $<1 \times 10^{-5} \mathrm{Ci} / 1,(370 \mathrm{kBq} / \mathrm{l})$ ); Intermediate-Level (specific activity $1 \times 10^{-5}$ to $1 \mathrm{Ci} / 1,(370 \mathrm{kBq} / 1$ to $37 \mathrm{GBq} / \mathrm{l})$ ); High-Level (specific activity $>1 \mathrm{Ci} /(>37 \mathrm{GGq} / 1)$ ).

6. For each category, the annuai volume of liquid radioactive waste produced is:

$$
\begin{array}{ll}
\text { Low-Level and Intermediate-Level } & 2,044 \mathrm{~m}^{3} \text { per year; } \\
\text { High-Level } & 100 \mathrm{~m}^{3} \text { per year. }
\end{array}
$$

7. The capacity of the tanks for liquid waste storage $\left(\mathrm{m}^{3}\right)$ are: 


\begin{tabular}{|c|c|c|}
\hline \multicolumn{3}{|c|}{ Table 6} \\
\hline \multicolumn{3}{|c|}{ Ukrainian Liquid Waste Storage Tank Capacities $\mathrm{m}^{3}$} \\
\hline NPP Site & Evaporator Bottoms & Ion-Exchange Resins \\
\hline Chemobyl & 28,000 & 15,000 \\
\hline Rivne & 6,150 & 1,580 \\
\hline South Ukraine & 4,115 & 400 \\
\hline Khmelnitsky & 800 & 200 \\
\hline Zaporozhye & 4,600 & 400 \\
\hline
\end{tabular}

8. Currently, Zaporozhye and Khmeinitsky NPPs have evaporator facilities with a $500 \mathrm{l} /$ hour capacity.

9. Solid radioactive wastes are classified as follows:

\section{Table 7}

\begin{tabular}{|l|c|c|c|}
\hline \hline \multicolumn{4}{|c|}{ Ukrainian Solid Waste Classifications } \\
\hline \multicolumn{1}{|c|}{ Classification } & $\begin{array}{c}\text { Radiation dose at } 10 \\
\text { cm from the surface, } \\
\mathrm{mr} / \mathrm{hr}\end{array}$ & $\begin{array}{c}\text { Beta Specific } \\
\text { Activity } \\
\mathrm{Ci} / \mathrm{kg}\end{array}$ & $\begin{array}{c}\text { Alpha Specific } \\
\text { Activity } \\
\mathrm{Ci} / \mathrm{kg}\end{array}$ \\
\hline Low-Level & $0.03-30$ & $2 \times 10^{-6}-1 \times 10^{-4}$ & $2 \times 10^{-7}-1 \times 10^{-5}$ \\
\hline Intermediate-Level & $30-1.000$ & $1 \times 10^{-4}-1 \times 10^{-3}$ & $1 \times 10^{-5}-1 \times 10^{-2}$ \\
\hline High-Level & $>1000$ & $>1 \times 10^{-1}$ & $>1 \times 10^{-2}$ \\
\hline
\end{tabular}

Technical Evaluation of Proposed Ukrainian Radioactive Waste Processing Facility 


\subsubsection{Radioactive Waste Information Presented by Ukrainian Scientific Research and Design Institute for Industrial Technology}

The final responses to the questions submitted by PNNL are contained in Reference [27]. These responses were prepared by the Ukrainian Scientific Research and Design Institute for Industrial Technology at the request of Goskomatom. The responses to the questions are as follows:

\section{Response to Question 1:}

The following reports were produced at the instruction of Goskomatom: "Concept for Ukrainian Radioactive Waste Handling" - 1993; "General Schedule for the Development of the Ukrainian Radioactive Waste Handling Industry" - 1993. The basis for these documents was Decree No. 44/93-RP of the President of Ukraine of April 14, 1993. A "Feasibility Study for Development of a Ukrainian Central Radioactive Waste Processing Facility" is planned for 1996.

\section{Response to Question 2:}

The following classes of licenses are issued for activities associated with the use of nuclear power under the "Ukrainian Law on the Use of Atomic Energy and Radiation Safety" (Article 28): (1) licenses for design, construction, extraction, production, manufacturing, purchase, sales, ownership, commissioning, operation, use, transport, decommissioning and conservation of any ionizing radiation source at a nuclear facility; (2) a license for surveying for site selection for a nuclear facility or an installation designated fro radioactive waste handling. The same document (Article 29) stipulates the terms and procedure for issuing permits relating to use of nuclear power; (3) Requirements for radioactive waste handling are also stipulated by another document entitled "Ukrainian Law on Handling of Ukrainian Radioactive Waste."

Response to Question 3:

It is not anticipated that liquid radioactive waste will be transported from nuclear power plants to the CRWPF. Treatment of the liquid radioactive waste will include the following: a sedimentation tank: mechanical processing: treatment employing activated charcoal; a waste evaporator and radio nuclide treatment employing resins (ion exchange treatments).

Response to Question 4

It is anticipated that the CRWPF will handle treatment of the full range of nuclear power plant waste with low and medium level radioactivity. The volume anticipated during decommissioning of the Chomobyl Nuclear Power has not been determined. 


\section{Response to Question 5:}

The capital investment schedule for establishment of the CRWPF is presented in the following table:

\begin{tabular}{|c|c|c|}
\hline \multicolumn{3}{|c|}{ Table 8} \\
\hline CRWPF Equipment/Facilities & $\begin{array}{l}\text { Quantity Required, } \\
\text { Units }\end{array}$ & Total Cost U.S \\
\hline $\begin{array}{l}\text { 1. Containers/Casks: } \\
\text { - Compaction Containers } \\
\text { - Ash Containers } \\
\text { - Transport Containers } \\
\text { - Radioactive Waste Storage Casks } \\
\text { - Retumable Containers }\end{array}$ & $\begin{array}{c}7700 \\
50 \\
50 \\
1000 \\
2280\end{array}$ & $\begin{array}{r}\$ 116,000.00 \\
\$ 750.00 \\
\$ 50,000.00 \\
\$ 1,100,000.00 \\
\$ 34,000.00\end{array}$ \\
\hline 2. Special Vehicles & 20 & $\$ 240,000.00$ \\
\hline 3. Special Purpose Railway Cars & 10 & $\$ 100,000.00$ \\
\hline 4. Compacted Radioactive Waste Drying Unit & 1 & $\$ 500,000.00$ \\
\hline 5. Radioactive Waste Combustion Unit & 1 & $\$ 4,000,000,00$ \\
\hline 6. Compactor & 1 & $\$ 400,000.00$ \\
\hline 7. Mobile Oil Treatment and Regeneration Unit & 1 & $\$ 400,000.00$ \\
\hline 8. Molten Salt Treatment and Processing Unit & 1 & $\$ 400,000.00$ \\
\hline 9. Ionite Processing Unit & 1 & $\$ 400,000.00$ \\
\hline $\begin{array}{l}\text { 10. Facility for Equipment and Container/Cask } \\
\text { Testing }\end{array}$ & 1 & $\$ 400,000,00$ \\
\hline $\begin{array}{l}\text { 11. Temporary Surface Storage Facility for } \\
\text { Radioactive Waste from Nuclear Power Plants }\end{array}$ & 1 & $\$ 30,000.00$ \\
\hline 12. Metallic Radioactive Waste Processing Unit & 1 & $\$ 16,000,000.00$ \\
\hline 13. Cementation Unit & 1 & $\$ 500,000.00$ \\
\hline $\begin{array}{l}\text { 14. Unit for Fabrication of Rebar Concrete } \\
\text { Casks for Radioactive Waste Storage }\end{array}$ & 1 & $\$ 500,000.00$ \\
\hline
\end{tabular}

Technical Evaluation of Proposed Ukrainian Radioactive Waste Processing Facility 


\begin{tabular}{|l|c|r|}
\hline \multicolumn{3}{|c|}{ Table 8 } \\
\hline \hline CRWPF Equipment/Facilities & $\begin{array}{c}\text { Quantity Required, } \\
\text { Units }\end{array}$ & Total Cost U.S \\
\hline 15. Radioactive Waste Fragmentation Unit & 1 & $\$ 500,000.00$ \\
\hline 16. Auxiliary Equipment & 1 & $\$ 500,000.00$ \\
\hline $\begin{array}{l}\text { 17. Storage Facility for Conditioned } \\
\text { Radioactive Waste }\end{array}$ & 1 & $\$ 30,000,000.00$ \\
\hline $\begin{array}{l}\text { 18. Accounting, Monitoring, Communications } \\
\text { and Physical Security System }\end{array}$ & 1 & $\$ 1,500,000.00$ \\
\hline 19. Laboratory Equipment & 1 & $\$ 4,000,000.00$ \\
\hline TOTAL: & - & $\$ 61,670,750.00$ \\
\hline $\begin{array}{l}\text { Scientific Research, Survey Costs (10\% of } \\
\text { Total) }\end{array}$ & - & $\$ 6,167,000.00$ \\
\hline Other Costs & - & $\$ 13,200,000.00$ \\
\hline TOTAL: & - & $\$ 81,037,750.00$ \\
\hline
\end{tabular}

\section{Response to Question 6:}

The Ukrainian classification for liquid radioactive wastes were listed and are identical to those provided in item 5 of the initial response. Liquid radwaste is stored separately depending on type and origins: (1) evaporator bottoms with salt concentration under $500 \mathrm{~g} /$ (from the evaporators) is stored in evaporator bottom vesseis; (2) slurries and filtrant media are stored in filtrant media storage vessels. Floor drain water is stored in floor drain tanks.

Technical Evaluation of Proposed Ukrainian Radioactive Waste Processing Facility 


\begin{tabular}{|l|l|l|l|}
\hline \multicolumn{4}{|c|}{ Table 9 } \\
\hline \hline \multicolumn{3}{|c|}{ Quantity of Liquid Radwaste by Nuclear Power Plant, $\mathbf{m}^{\mathbf{3}}$} \\
\hline \multirow{2}{*}{ Power Plant } & \multicolumn{3}{|c|}{ Type of Radwaste } \\
\cline { 2 - 4 } & Evaporator Bottoms & $\begin{array}{l}\text { Water Containing } \\
\text { Ion-Exchange } \\
\text { Resins and Filtrant } \\
\text { Media }\end{array}$ & $\begin{array}{l}\text { Radioactive } \\
\text { Lubricants and Oils }\end{array}$ \\
\hline KNPP & 686 & 100 & no data \\
\hline RNPP & 5000 & 250 & 60 \\
\hline ZNPP & 4600 & 385 & no data \\
\hline SUNPP & 2814 & 398 & no data \\
\hline CNPP & 10186 & 4837 & no data \\
\hline
\end{tabular}

The Zaporozhye and Khemelnitskiy Nuclear Power Plants contain units for converting evaporator bottoms into molten salt with a salt concentration of up to $1600 \mathrm{~g} /$. At the Rivne Nuclear Power Plant, this unit was developed by the Ukrainian Scientific Research and Design Institute for Industrial Technology and will be placed into service in 1997. The quantity of molten salt in 200 liter barrels at the $\mathrm{ZNPP}$ and KNPP is $4200 \mathrm{~m}^{3}$ and $1100 \mathrm{~m}^{3}$ respectively.

The annual volume of liquid radwaste for nuclear power plants employing VVER-1000 reactors is:
(1) Evaporator Bottoms
$86 \mathrm{~m}^{3} / \mathrm{yr}$
(2) lon exchange resins and filtrant media
$15 \mathrm{~m}^{3} / \mathrm{yr}$

The following vessels are available for storing liquid radwaste at nuclear power plants

At the Zaporozhye Nuclear Power Plant:

(1) The available volume for storage of evaporator bottoms and filtrant media as well as deposits is $4800 \mathrm{~m}^{3}$ (the capacity of each vessel ranges from 100 to $750 \mathrm{~m}^{3}$ )

(2) The capacity for storage of floor drains: six $200 \mathrm{~m}^{3}$ capacity floor drain vessels for a total of $1200 \mathrm{~m}^{3}$; four $40 \mathrm{~m}^{3}$ laundry control vessels for a total of $160 \mathrm{~m}^{3}$ : two 40 $\mathrm{m}^{3}$ vessels for storing contaminated water from the laundry for injection to the evaporators for a total of $80 \mathrm{~m}^{3}$. The total capacity for the storage of floor drains is then $1440 \mathrm{~m}^{3}$.

Technical Evaluation of Proposed Ukrainian Radioactive Waste Processing Facility 
At the Khemeinitskiy Nuclear Power Plant:

(1) As of May 1, 1995 the plant contained five vessels with a capacity of $800 \mathrm{~m}^{3}$ and is assembling three vessels for the second series units with a capacity of $700 \mathrm{~m}^{3}$ each.

At the Rivne Nuclear Power Plant:

(1) Total storage capacity for liquid radwaste is $6150 \mathrm{~m}^{3}$ for storage of evaporator bottoms.

(2) Total vessel storage space for ion-exchange resins and sorbents is $1580 \mathrm{~m}^{3}$.

At the South Ukraine Nuclear Power Plant:

(1) Total vessel capacity for storage of molten salt is $4,114 \mathrm{~m}^{3}$.

(2) Total storage capacity for ion-exchange resins and sorbents is $400 \mathrm{~m}^{3}$.

At the Chomobyl Nuclear Power Plant:

(1) Total vessel capacity for storage of evaporator bottoms is $28000 \mathrm{~m}^{3}$.

(2) Total vessel storage for ion-exchange resins and sorbents is $15000 \mathrm{~m}^{3}$.

All nuclear power plants have evaporators to produce evaporator bottoms.

The Ukrainian classifications for solid radioactive wastes by dose rate and activity were provided and are consistent with those provided in the initial response, see Table 7. Solid radioactive waste is divided into the following classifications based on physical composition and characteristics: combustible/noncombustible; metallic/nonmetallic; compactable/noncompactable and stored in special vessels and in reactor containment.

Technical Evaluation of Proposed Ukrainian Radioactive Waste Processing Facility 


\section{Table 10}

\begin{tabular}{|l|c|}
\hline \multicolumn{2}{|c|}{$\begin{array}{c}\text { Composition of Solid Radioactive Waste } \\
\text { (Example from Zaporozhye Nuclear Power Plant) }\end{array}$} \\
\hline \multicolumn{1}{|c|}{ Type of Waste } & Composition \% \\
\hline Special Clothing & 26.6 \\
\hline Plastics & 9.31 \\
\hline Thermal Insulation & 13.3 \\
\hline Paper & 3.33 \\
\hline Rubber & 1.33 \\
\hline Filters & 3.59 \\
\hline Wood & 2.68 \\
\hline Metal & 14.52 \\
\hline Concrete (dry) & 0.67 \\
\hline Glass & 0.67 \\
\hline Sorbents & 0.665 \\
\hline Other & 23.34 \\
\hline
\end{tabular}

Solid radioactive waste is stored based on its components and radioactivity in the appropriate cells of solid radwaste storage facilities:
(l) thermal insulation;
(2) metal;
(3) ion-exchange resin;
(4) fine aggregate concrete following reconstruction;
(5) removable filters;
(6) ash;
(7) paper;
(8) contaminated tools;
(9) other waste. 


\begin{tabular}{|c|c|c|}
\hline \multicolumn{3}{|c|}{ Table 11 } \\
\hline \multicolumn{3}{|c|}{$\begin{array}{c}\text { Volume of Solid Radwaste by Nuclear Power Plant } \\
\text { and Design Storage Capacity, } \mathbf{m}^{\mathbf{3}}\end{array}$} \\
\hline Power Plant & Accumulated Solid Radwaste & Design Capacity \\
\hline RNPP & 3000 & 10905 \\
\hline KNPP & 1163 & $45544^{(1)}$ \\
\hline SUNPP & 8697 & 14500 \\
\hline ZNPP & 10531 & 17000 \\
\hline CNPP & 3019 & 15900 \\
\hline Sarcophagus & 790000 & - \\
\hline
\end{tabular}

Note (1) This design capacity may be in erтor as KNPP is a single unit plant.

All solid radwaste at the Khemelnitskiy, South Ukraine and Chornobyl Nuclear Power Plants are not conditioned, but rather are stored "in bulk" without containers in solid radwaste storage facilities. Solid radwaste (compressed) is additionally compressed into 200 liter drums at the Zaporozhye Nuclear Power Plant. Only combustible solid radwaste is compacted and packaged at the Rivne Nuclear Power Plant.

Response to Question 7:

The response to Question 7 is addressed in Section 3.1 which covers the design information for the proposed central facility.

Response to Question 8:

The isotope composition of solid radwaste and ash samples from the Zaporozhye Nuclear Power Plant is presented in Table 12 


\section{Table 12}

\begin{tabular}{|c|c|c|c|c|c|c|}
\hline \multicolumn{7}{|c|}{$\begin{array}{c}\text { Solid Radwaste Samples from the Reactor Hall of Unit No. 4, } \\
\text { Zaporozhye Nuclear Power Plant }\end{array}$} \\
\hline \multirow{2}{*}{$\begin{array}{l}\text { Type of } \\
\text { Waste }\end{array}$} & \multirow{2}{*}{$\begin{array}{l}\text { Total } \\
\text { Activity } \\
\mathrm{Ci} / \mathrm{kg}\end{array}$} & \multicolumn{5}{|c|}{ Isotope Composition and Specific Activity, $\mathrm{Ci} / \mathrm{kg}$} \\
\hline & & $C^{134}$ & $\mathrm{C}^{137}$ & $\mathrm{Co}^{58}$ & $\mathrm{Mn}^{54}$ & $\mathrm{Co}^{(*)}$ \\
\hline $\begin{array}{l}\text { Thermal } \\
\text { Insulation }\end{array}$ & $5.1 \times 10^{-10(1)}$ & $4.4 \times 10^{-11}$ & $5 \times 10^{-11}$ & - & $6.7 \times 10^{-11}$ & $6 \times 10^{-11}$ \\
\hline $\begin{array}{l}\text { Rags- } \\
\text { Clothing }\end{array}$ & $4.8 \times 10^{-7}$ & $2.5 \times 10^{-8}$ & - & $2 \times 10^{-7}$ & $1 \times 10^{-7}$ & $1.8 \times 10^{-7}$ \\
\hline Concrete & $3.1 \times 10^{-10(1)}$ & - & $9.7 \times 10^{-11}$ & - & $7.2 \times 10^{-11}$ & $1.4 \times 10^{-10}$ \\
\hline \multicolumn{7}{|c|}{ Isotope Composition and Specific Activity of Ash Residue } \\
\hline \multirow{2}{*}{$\begin{array}{l}\text { Date of } \\
\text { Analysis }\end{array}$} & \multirow{2}{*}{$\begin{array}{l}\text { Total } \\
\text { Activity } \\
\mathrm{Ci} / \mathrm{kg}\end{array}$} & \multicolumn{5}{|c|}{ Isotope Composition and Specific Activity, $\mathrm{Ci} / \mathrm{kg}$} \\
\hline & & $C^{134}$ & $\mathrm{C}^{137}$ & $\mathrm{Co}^{58}$ & $\mathrm{Mr}^{54}$ & $\mathrm{Co}^{\circ 0}$ \\
\hline $04 / 16 / 88$ & $2.6 \times 10^{-9(1)}$ & $4.5 \times 10^{-10}$ & $1.3 \times 10^{-9}$ & $3.8 \times 10^{-11}$ & $3.9 \times 10^{-10}$ & $3.1 \times 10^{-10}$ \\
\hline $04 / 24 / 89$ & $1.4 \times 10^{-8}$ & $1.3 \times 10^{-10}$ & $3.6 \times 10^{-10}$ & $5.1 \times 10^{-10}$ & I. $7 \times 10^{-8}$ & 1. $1 \times 10^{-8}$ \\
\hline $02 / 09 / 90$ & $1.3 \times 10^{-9(1)}$ & - & $8.6 \times 10^{-11}$ & - & $3.2 \times 10^{-10}$ & $9.7 \times 10^{-10}$ \\
\hline
\end{tabular}

NOTE (1) PNNL recognizes that the total activity levels reported are very low (below those typically found in the human body) and may not be of significant concern.

Response to Question 9:

Class 1 and 2 waste will be processed at the CWRPF (see response to question 7).

Response to Question 10:

All equipment which will be periodically decontaminated is to be fabricated from corrosionresistant material.

Response to Question 11:

Monitoring and analysis links currently in use at the operating nuclear power plants will be used. This issue will be discussed in greater detail during the development of the feasibility study for the 


\section{CWRPF.}

\subsubsection{Radioactive Waste Information Provided by the Ukrainian Ministry of Environmental Safety}

Reference [17] is a 1994 status report on nuclear and radiation safety in Ukraine issued by the Ukrainian Ministry of Environmental Protection and Nuclear Safety and their Nuclear Regulatory Administration. The status report broadly outlined and described the radioactive waste handling situation in Ukraine as follows:

The Ukraine Cabinet of Ministers has designated Goskomatom as the agency responsible for organizing the safe handling of radioactive wastes in industry and for collecting, processing, and storing them until the radiaactive wastes are shipped for burial. The management and handling of radioactive wastes during long-term storage and burial is under the jurisdiction of the Ukraine Ministry for Mitigating the Consequences of the Chornobyl Disaster.

The following general problems were described:

- lack of a well developed regulatory base,

- lack of a radiaactive waste accounting and control system,

- lack of a well developed national scientific and industrial base,

- lack of a national plan for the long-term handling of radioactive wastes,

- lack of a sufficient number of qualified specialists.

Because the problem of final burial of radioactive wastes in Ukraine has not yet been solved, an approach has been adopted which provides for long-term storage of radioactive wastes in specially monitored storage facilities. A large group of scientists and specialists from Ukrainian Academy of Sciences, institutes, ministries, and agencies has been formed to study the storage and burial of radioactive wastes. The preliminary results have been positive, and several sites whose geological structure is suitable for radioactive waste burial have been identified.

Ukraine now has six main radioactive waste storage points which operate as special subdivisions of the Radon State Association; these were built as far back as 1959-1962. The sites are located at Kharkov, Odessa, Lvov, Dnepropetrovsk (being rebuilt), Kiev (shutdown) and Donetsk (mothballed). All of these special facilities must be fundamentally rebuilt, equipped with modern process equipment, and brought into compliance with current requirements, regulations and standards. In not a single instance does radwaste facility documentation contain a section on "Radiation Monitoring. " Documentation for the first units at radwaste burial sites has not been

Technical Evaluation of Proposed Ukrainian Radioactive Waste Processing Facility 
assembled, and there are no receipt control reports.

The problem of radioactive waste handling at the Eastern Mining and Ore Processing Enterprises (Zheltye Vody) is acute. It has accumulated a large amount of gangue (waste rock) containing radioactive isotopes or uranium, thorium, and radium. There is also a large amount of liquid radioactive wastes from enrichment and hydro metallurgical manufacturing and underground leaching sites. The approximate total activity. concentrated at these sites, which are located in densely populated regions of Ukraine, is about 140,000 curies.

Handling radioactive wastes created as a result of the Chornobyl disaster is a serious problem. A large portion of these wastes have been buried in temporary storage facilities which are in complete non-compliance with current requirements, standards, and regulations. Registered temporary Chornobyl radioactive waste localization and burial sites have a total radioactive waste activity of about 300,000 curies.

Nuclear power stations are among the main praducers of radioactive waste in Ukraine. In 1994 nuclear power plants with VVER reactors accumulated about 47,000 cubic meters of radioactive wastes, half of which are liquid.

Not a single Ukrainian nuclear power plant has solved the problems of processing liquid radioactive wastes and safe long-term storage of the solidified praduct. Bituminization units installed at the South Ukraine and Rovno Nuclear Power Plants capable of yielding a product with acceptable characteristics are not currently in operation. The reason for this at the South Ukraine plant is the lack of bitumen of the required quality; at Rovno. the fact that construction of a storage facility which meets the requirements for safe longterm storage of solidified product is incomplete. Deep concentration plants (evaporators) in operation at Zaporozhye and Khmelnitsky do not solve the problem. because the characteristics of the product are such that it is doubtful whether it can be burted or transported without very expensive preventative measures for which the engineering and technology have not been developed. The problem is not being resolved because Ukraine does not produce its ow'n casks for solidifled radioactive wastes and the service life guarantee on casks bought $\mathrm{m}$ Russia is limited. It is simply being put off for a few years. In addition, the problem of large-sized wastes, as well as waste such as lowactivity fuels and contaminated thermal insulation, must be solved. The lack of technologies and equipment for processing them result in larger amounts of radioactive waste requiring storage than might otherwise be anticipated.

The main problems in handling radioactive waste at L/kraine's muclear power plants are:

- they exceed design and regulatory requirements for recoverable liquid radwaste

Technical Evaluation of Proposed Ukrainian Radioactive Waste Processing Facility 
(a major source of liquid radioactive wastes at nuclear power plants),

- liquid radioactive waste solidifiers are primitive, inadequate in number, or entirely lacking,

- $\quad$ safe handling of large-sized waste formed during outages, post-accident remediation, or retrofitting and modernization is not dealt with in muclear power plant designs,

- Ukraine does not have special design and engineering organizations or mamufactures of equipment for nuclear power plants.

The handling of radioactive wastes in inchustry, agriculture, science, and medicine causes serious concern. Because there is no closed system of accountancy and state registration of ionizing radiation sources, radioactive wastes may be created that are not recorded and, in the best case, disposed of at ordinary mumicipal dumps.

If the draft General System for Developing the Radioactive Waste Handling Industry ( now being revised by Goskomatom) is adopted, we do have prospects for solving these problems.

\subsection{Wastes Located Within 30-km Zone and the Unit 4 Sarcophagus}

The types and quantities of radioactive waste in the $30-\mathrm{km}$ Zone around the Chomobyl NPP site and within the destroyed unit 4 Sarcophagus are for obvious reasons difficult to quantify. However, research has been conducted and estimates have been made. For example, in Reference [20] the type, quantity and activity of radioactive waste formed in the $30-\mathrm{km}$ Zone are estimated as follows

\begin{tabular}{lcc}
\multicolumn{1}{c}{ Waste Type } & Quantity. Metric Tons & Total Activity, Ci \\
\cline { 2 - 2 } Vegetation & $1.0 \times 10^{9}$ & 150,000 \\
Structural Materials & $3.5 \times 10^{5}$ & 60,000 \\
Contaminated Ground & $2.0 \times 10^{8}$ & 40,000 \\
Garbage & $3.0 \times 10^{5}$ & 20,000 \\
Scrap Metal & $4.0 \times 10^{5}$ & 15,000 \\
Forest (woods) & $3.0 \times 10^{5}$ & 10,000 \\
Silt & $2.0 \times 10^{6}$ & 5,000 \\
Contaminated Buildings & $3.0 \times 10^{6}$ & 3,500 \\
Contaminated Water & $5.0 \times 10^{7}$ & 100 \\
Total & $1.2 \times 10^{9}$ & 303,600 \\
\end{tabular}


Several engineered disposal sites were built within the 30-km Zone, but a significant portion of the waste is disposed of in approximately 600 to 800 temporary storage trenches with no waterproof barriers. The volume of radioactive waste stored in the destroyed unit 4 Sarcophagus is estimated to be 100 times larger than the total volume of waste stored in the interim storage facilities (PVLROs) and disposal facilities (PZROs). The total volume stored in the PZROs and the PVLROs is approximately $1.1 \times 10^{9} \mathrm{~m}^{3}$. Therefore, this estimate for total volume of radioactive waste stored in the destroyed unit 4 sarcophagus would be approximately $110 \times 10^{9}$ $\mathrm{m}^{3}$, Ref. [21]. This reference must be verified against other references; $110 \times 10^{9} \mathrm{~m}^{3}$ is a cube with sides approximately 3 miles in length, which is unlikely, the Sarcophagus is not that large Reference [23] indicates there is approximately $1.0 \times 10^{6} \mathrm{~m}^{3}$ of radioactive waste with a total activity of $380,000 \mathrm{Ci}$ stored in the temporary trenches, which exceed 800 in number.

The Sarcophagus itself was constructed as a temporary structure in only seven months using, depending upon the reference, between 300,000 to 720,000 tons of concrete and 7,000 tons of steel Refs. [22 \& 26]. The Sarcophagus is seen as a provisional barrier pending the identification and completion of a solution for elimination of the destroyed reactor and the safe disposal of the high level radioactive material stored within. The estimates of Reference [23], a 1996 status report, place the total quantity of fuel and fuel containing masses within the Sarcophagus at approximately 180 tons with an activity of approximately $20 \times 10^{6} \mathrm{Ci}$. Before the accident Unit 4 had approximately 190.3 tons of irradiated fuel in the core, 19.5 tons of spent fuel in the spent fuel storage facility and 2.3 tons of fresh fuel $(20$ fresh fuel assemblies in the Central Hall, Ref [26]). In addition, there are large quantities of destroyed core internals, reactor graphite, contaminated structural elements, and approximately 3,000 to $3,500 \mathrm{~m}^{3}$ of water. References [24 $\& 25$ ] summarize the forms of the 180 tons of irradiated fuel within and around the Sarcophagus as follows: "(1) Fragments of active core, most of which was hurled to the upper levels of the Central Hall and are covered by the material dispersed from Helicopters in 1986. (Estimates place the material dropped from Helicopters at over 5,000 tons consisting of: 2400 tons of lead, 1800 tons of sand and clay, 800 tons of dolomite. and 40 tons of boron carbide.) Information about the fuel in the Central Hall is limited. (2) Finely dispersed fuel dust and hot fuel particles which measure from fractions of microns to hundreds of microns. These particles are practically everywhere in the Sarcophagus and in the soil in the vicinity of the plant and further afield. The total amount of fuel in this form is estimated roughly at 10 tons. (This number is only considered very approximate.) (3) Solid lava-like fuel-containing masses which were formed during the active phase of the accident by high temperature interaction of the fuel with the structural materials in the plant. There is considerable information about the lava in the lower regions - its location and physio-chemical features, but not about the total quantity which is estimated to be in the range of 70-150 tons. (4) Soluble forms of plutonium, americium and uranium, which is found in water about $1 \mathrm{mg} /$ liter. (5) About 0.5 to $l$ ton of the fuel remains on the ground around the Sarcophagus, under a layer of concrete and gravel." Some estimates place the total amount of radioactive waste in and around the Sarcophagus that will eventually have to be managed at approximately 350,000 tons.

Technical Evaluation of Proposed Ukrainian Radioactive Waste Processing Facility 
Reference [23] describes and estimates the volume of operations related waste accumulated at the CNNP site as follows: solid wastes more than $40,000 \mathrm{~m}^{3}$, liquid waste approximately $25,000 \mathrm{~m}^{3}$, and approximately 14,000 spent cassettes stored at the spent fuel storage site. As a result of continuing operation of the remaining two units $2,000 \mathrm{~m}^{3}$ of solid wastes and $870 \mathrm{~m}^{3}$ of liquid wastes are released annually Ref. [23]. 
Figure 2.1 Forecasts for Ukrainian Liquid Waste Volumes and Storage Capacities

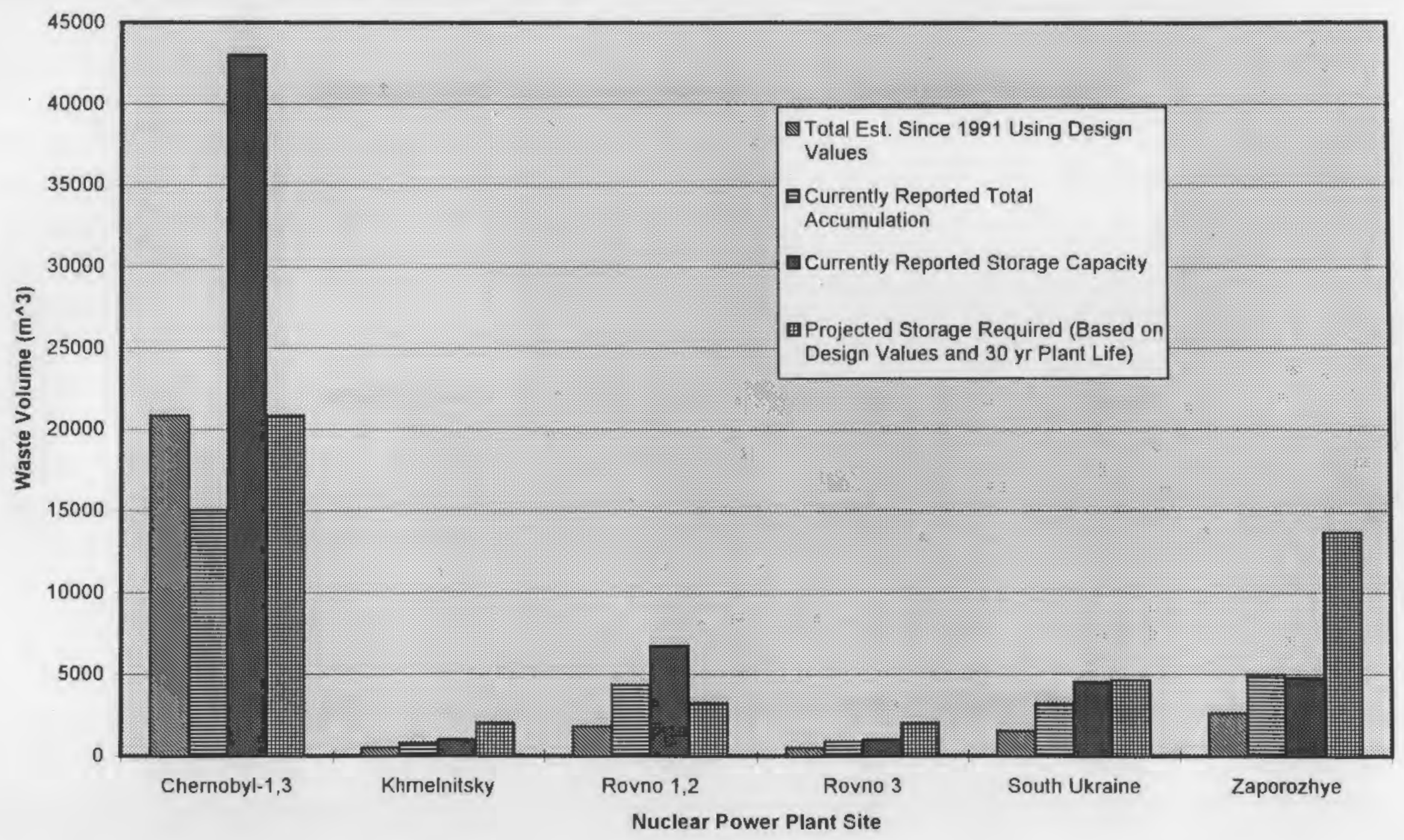

Technical Evaluation of Proposed Ukrainian Radioactive Waste Processing Facility Page 2.25 
Figure 2.2 Forecasts for Ukrainian Solid Waste Volumes and Storage Capacities

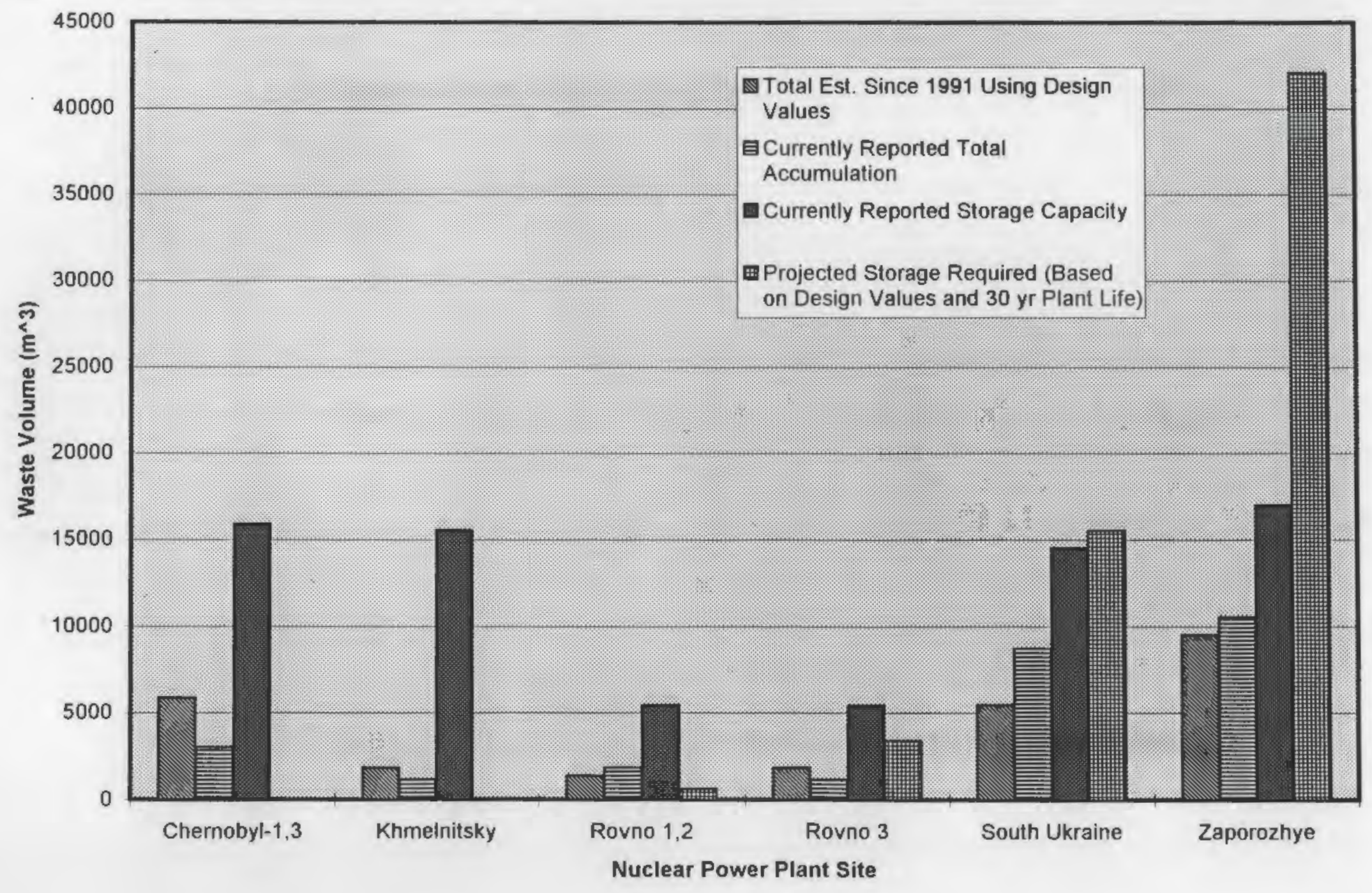

Technical Evaluation of Proposed Ukrainian Radioactive Waste Processing Facility Page 2.26 


\section{Estimated 30 yr Operations and Decommissioning Total Waste Volumes by Year of Plant Shutdown}

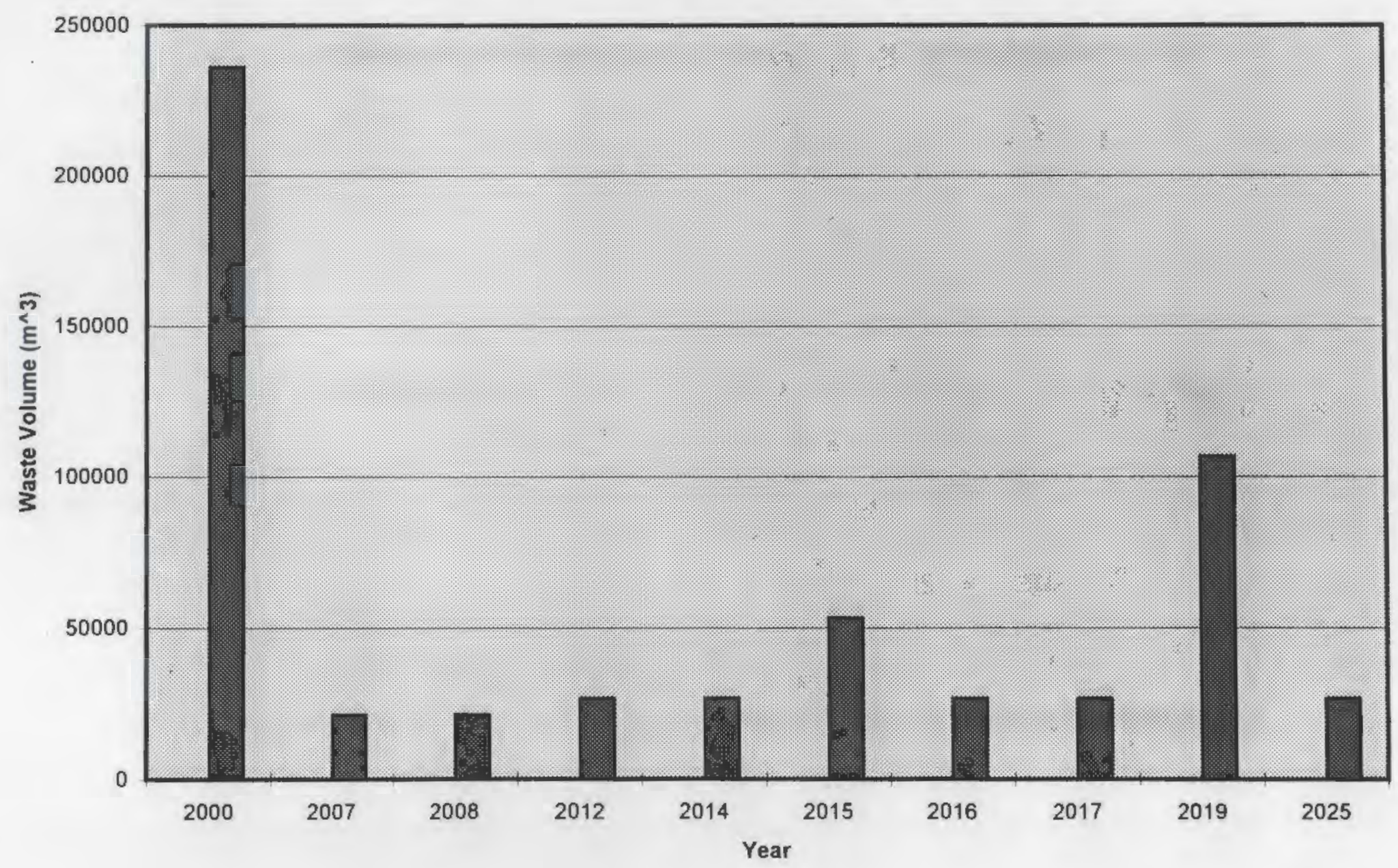

Technical Evaluation of Proposed Ukrainian Radioactive Waste Processing Facility Page 2.27 
Distribution of Waste Forms, Totals for All Ukrainian NPPs, Not Including the Sarcophagus or $\mathbf{3 0} \mathrm{km}$ Zone Wastes

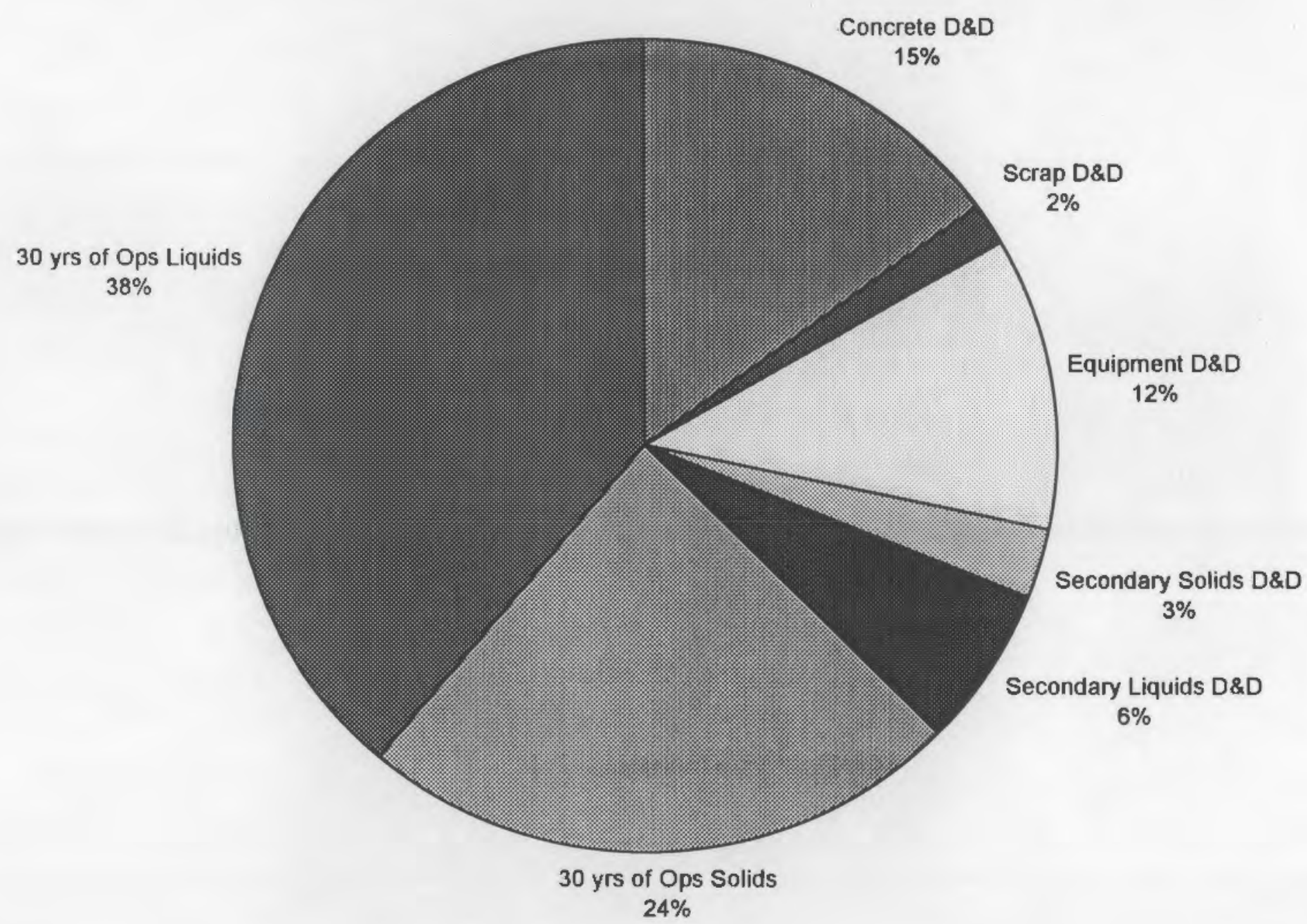




\subsection{Options Available for Solution of Ukrainian Radioactive Waste Problem}

There are several options available for radioactive waste processing for the Ukrainian NPPs. Goskomatom along with other organizations, including the Ukrainian Scientific Research and Design Institute for Industrial Technology and the Ukrainian Academy of Sciences, have proceeded with a conceptual model for Ukrainian radioactive waste management. General information on the proposed Ukrainian approach was outlined in Ref. [10] which states,

"The radioactive waste of NPP's is stored at special storage facilities on the site. During the design of NPP's, little attention was paid to radwaste treatment. This is why radwaste management in Ukraine is among the priority issues of Goskomatom of Ukraine. Together with the Ukrainian Academy of Sciences, Goskomatom finalized in 1993 the development of the Concept for Ukrainian Radwaste Management and the General Scheme of the Development of Radwaste Management in Ukraine. The final stage of the process will be the development of the National Programme on Establishing the Radwaste Management Industry, in which the responsible executives and the scopes and sources of financing are to be defined. New Technologies for radwaste processing and new containers for long term storage of wastes of all types have been developed.

It has been decided to establish and develop a centralized radwaste processing facility. This will enable us to carry out centralized processing activities and reliable storage of the radwastes of all NPPS at one site, which would eliminate the need to reprocess the waste at each NPP.

Technological developments by Ukrainian scientists together with the design and manufacturing experience of Russian industrial installations, as well as possible participation of foreign firms should make it possible for us to solve the radwaste processing problem within the nexi four to five years, provided the work is properly organized."

The Ukrainian Ministry for Chomobyl Affairs in Reference [23] described a scientific and technological center for radioactive wastes complex management that has been set up in Zhovti Vody (Dnipropetrovsk region) for the purpose of implementing decontamination and recovery projects. This center focuses on the decontamination of settlements but has also designed and built burial sites for the wastes generated during decontamination effors.

Detailed technical information on the proposed centralized radioactive waste processing facility was requested from Goskomatom and is discussed in Section 2.3 and below in Section 3.1. It is recommended that existing levels of initial processing occurring at the plant sites continue and

Technical Evaluation of Proposed Ukrainian Radioactive Waste Processing Facility 
that potential upgrades to initial on-site processing be considered. The central processing facility should not be designed to handle the unprocessed liquid radioactive waste streams from all of the Ukrainian NPPs. The total generation rate of unprocessed liquid radioactive wastes was estimated in Appendix A at $2275 \mathrm{~m}^{3} /$ day $(601,000 \mathrm{gal} /$ day $)$. Handling this quantity of unprocessed waste at a central facility would be difficult considering the logistics of transport, storage, number of process trains required and necessary process rates.

The options chosen for initial processing at the plant sites and final processing at the central facility will impact the overall economics. The main techniques for treatment of the unprocessed wastes at the plant site consist of: ion-exchange treatment, filtration treatments, evaporation. chemical precipitation to produce a sludge, separation systems, reverse osmosis, molten metal technologies and incineration. All of the above treatments are applied to low and intermediate level radioactive wastes and the results are concentrates such as resins, evaporator bottoms, powders and sludge, etc. These can then be processed at the central facility using treatment methods that may consist of: additional volume reduction, incineration, and solidification in concrete or bitumen which is then packaged for storage and disposal. Solid radioactive wastes from the NPPs can be transported to the central facility to be processed using compaction, supercompaction, segregation (combustible and non-combustible), incineration of combustibles, solidification of ash, and final packaging for storage and disposal.

Cost estimates are taken from Refs. [2,3,4 and 11] and from vendor supplied information. The cost estimates come from several references which are based upon different years. Therefore, all cost estimates have been adjusted to 1996 dollars using an assumed interest rate of $5.0 \%$ that combines the real discount rate and inflation rate from the estimates basis year.

The options presented below are compared using the present worth (in terms of costs) of the initial capital equipment investment and the yearly costs of operating the facilities to process and store the waste. It should be noted that total radioactive waste management costs are driven largely by the yearly processing and storage costs. Therefore, a higher initial capital cost required to install equipment that can significantly reduce the volume of wastes to be processed can reduce the overall costs associated with the life of the facility. In comparing the altemative options this analysis considered only the total present worth (in terms of costs) to select the preferred alternative. There may be other economic drivers and limitations that will impact the decision to select a preferred altemative, these items can be discussed individually when appropriate

\subsection{Ukrainian Design Information for Proposed Central Facility}

In response to queries for design information on the proposed central facility Goskomatom, through a report completed by the Ukrainian Scientific Research and Design Institute for Industrial Technology Ref. [27], provided the following information:

Tcchnical Evaluation of Proposed Ukrainian Radioactive Waste Processing Facility 
The following is planned for implementation at the Central Radioactive Waste Processing Facility

(1) extraction of molten salt, dried ionites, slurry and drum residue;

(2) extraction of borates from the molten salt,

(3) remelting of contaminated metal;

(4) thermochemical processing of spent sorbents and ion-exchange resins dried at the nuclear power plant;

(5) processing of combustible solid radwaste;

(6) drying of solid radwaste prior to compaction;

(7) compaction of pressed solid radwaste in drums;

(8) conversion of solid radwaste into insoluble forms (after preliminary conditioning) through bituminization, cementation or vitrification;

(9) storage of insoluble matrices containing solid radwaste in concrete casks.

The capacity of the processing units and storage capacity shall be determined during the feasibility analysis for development of the CRWPF, taking into account the annual production level of solid radwaste at nuclear power plants and waste from decommissioning of nuclear power plants. All equipment at the CRWPF shall be resistant to radiation, decontaminated solvents and shall have biological shielding, remote control capability; include dust and gas filtering systems and shall be licensed by Minekobezopastnost agencies. Class 1 and 2 radioactive waste will be processed at the CRWPF. The CRWPF will include automatic monitoring systems for monitoring the site radiation environment as well as environmental monitoring systems for the surrounding areas The equipment and pipelines will be reliable and operationally safe throughout their designed service life. All equipment which will be periodically decontaminated is to be fabricated from corrosion-resistance material.

\subsubsection{Ukrainian Cost Estimates for the Goskomatom Proposal}

Goskomatom in its initial letter to DOE Ref. [1] estimated a total cost of $\$ 40$ million dollars to construct the facility with roughly half going to capital equipment costs and half going to labor. PNNL requested details on the assumptions that went into this cost estimate. The final response to the PNNL request, in regard to capital equipment costs, were provided in Ref. [27]. The capital equipment costs provided by Ref. [27] are presented in Table 8 of this report. Total capital equipment costs were estimated by Ref. [27] to be $\$ 61.6$ million dollars.

\subsection{Liquid Waste Management Systems Options}

Liquid waste management systems consist of tanks for collection, followed by processing using one or more unit operations such as: filters, ion exchanger, separators and evaporators to achieve the necessary cleanup and volume reduction. The processing stage can be combined in several different ways to handle the different feed streams. Because the details of the proposed central radioactive waste processing facility are not finalized, an evaluation of options for combined

Technical Evaluation of Proposed Ukrainian Radioactive Waste Processing Facility 
operations and their necessary capabilities will be conducted instead. Different combinations of the operations are generated to offer options available for solution of the Ukrainian liquid radioactive waste problem. The options presented below are compared using the total present worth (in terms of total costs) of the initial capital equipment investment plus the yearly costs of operating the facilities over a 20 year lifetime and finally long term storage of the final waste form.

\subsubsection{Option 1 Description and Costs}

This option assumes that the existing liquid radioactive waste processing trains at the Ukrainian NPPs will be operated as designed and the concentrates: evaporator bottoms and resins will be transported to the central facility for further processing. Processing at the central facility follows the processes described for solid waste management options and includes concentration, solidification, packaging and storage prior to final disposal. The costs for this option are discussed under Section 3.3 Solid Waste Management System Options (Option 1).

\subsubsection{Option 2 Description and Costs}

This option upgrades the existing liquid radioactive waste processing trains at the Ukrainian NPPs using advanced volume reduction methods. Advanced volume reduction techniques have been developed that allow for reduction of waste volumes by approximately a factor of four or more depending upon the process chosen. These technologies are supplied by U.S. Vendors who currently have proven facilities in operation at U.S. Plants. This option reduces the volume of concentrates and resins and therefore the costs of further processing and disposal required at a central facility. The costs for this option include the capital cost of installing the mobile processing units at the individual plant sites and the cost of processing the reduced volumes of solid waste delivered to the central facility.

The per-unit capital equipment costs for a single advanced process/evaporator system supporting a single plant are estimated at $\$ 5,900,000$ to $\$ 13.300,000$. These estimates came from a recently completed U.S. vendor project in Valdivostok and Refs. [3 and 11] where process/evaporator systems supporting a single unit are given. The total capital equipment costs are higher when factoring in the number of Ukrainian NPPs ( 15 plants) and the centralized solidification system capable of handling the concentrated liquids and resins produced. However, cost savings could be realized by designing mobile units that service one NPP site (with 3,4, or 6 NPPs). In addition, the costs for a single mobile unit may be suitable to a multi-phased staggered approach where those plants with the severest process and storage problems are solved first. Increasing the above per unit cost estimate by a factor of $3(\$ 18$ to $\$ 40$ million) provides a total cost estimate that would be reasonable to support distributed operations, and still results in a total present worth (in terms of total costs) that is lower than Option 1. Advanced process/evaporator units have a wide range of potential configurations and options including: ion-exchanger, separators, dryers, crystallizer, etc. causing the large range in cost estimates.

Technical Evaluation of Proposed Ukrainian Radioactive Waste Processing Facility 
The yearly processing cost estimate for a mobile process/evaporator solution with a centralized solidification system is $\$ 4,425,000$ based upon the processing costs per cubic meter found in Ref. [11].

The capital equipment cost estimates for a centralized solids compactor system capable of processing the total estimated generation rates and volumes are in the range of $\$ 640,000$ to $\$ 2,560,000$. These estimates come from Refs. [3 and 11] where a compactor system supporting a single unit are estimated at $\$ 74,000$ to $\$ 295,000$. The individual unit estimates were adjusted to account for the required capacity to service 15 Ukrainian power plants and the decommissioning waste from three RBMK-1000s at Chernobyl.

The yearly processing cost estimate for a centralized solids compactor system for the operating NPPs is $\$ 8,570,000$ based upon the processing costs per cubic meter found in Ref. [11]. The yearly processing cost estimate for a centralized solids compactor system for the Chomobyl decommissioning waste is $\$ 9,050,000$ based upon the processing costs per cubic meter found in Ref. [11].

When evaluating the total present worth (in terms of total costs) for Option 2 it becomes clear that Option 2 is the preferred alternative in terms of minimizing total costs. Option 2 has a lower present worth (total cost), due to the fact that the yearly processing and storage costs are much lower for Option 2 (there is a smaller volume of concentrated waste to process and store). The total present worth is lower even though the initial total capital equipment costs are higher. 


\begin{tabular}{|l|c|c|}
\hline \multicolumn{3}{|c|}{ Table 13 } \\
\hline \multicolumn{2}{|c|}{ Least Cost Option \#2 - Capital Equipment Estimate Summary } \\
\hline \multicolumn{1}{|c|}{ Process Description } & Low Range & High Range \\
\hline Single Solids Compactor System & 74,000 & 295,000 \\
\hline $\begin{array}{l}\text { Central Compactor for all NPPs and CNPP } \\
\text { D\&D waste. }\end{array}$ & 640,000 & $2,560,000$ \\
\hline $\begin{array}{l}\text { Single Advanced Mobile } \\
\text { Process/Evaporator Unit }\end{array}$ & $5,900,000$ & $13,300,000$ \\
\hline $\begin{array}{l}\text { Three Advanced Mobile Process/Evaporator } \\
\text { Units }\end{array}$ & $17,700,000$ & $39,900,000$ \\
\hline Single Solidification Train & $1,000,000$ & $6,000,000$ \\
\hline $\begin{array}{l}\text { Central Solidification Train Processing all } \\
\text { NPPs and CNPP Operating Wastes }\end{array}$ & $1,500,000$ & $8,900,000$ \\
\hline $\begin{array}{l}\text { Storage Facility for all NPPs and CNPP } \\
\text { Solidified Liquids and Resins }\end{array}$ & $9,900,000$ & unavailable \\
\hline $\begin{array}{l}\text { Storage Facility for all NPPs and CNPP } \\
\text { Compacted Solids }\end{array}$ & $71,100,000$ & unavailable \\
\hline \begin{tabular}{l} 
Storage Facility for 3 RBMKs D\&D Waste \\
\hline
\end{tabular} & $73,700,000$ & unavailable \\
\hline
\end{tabular}

An initial schedule showing a work breakdown structure for the major components of the central processing and storage facilities follows. This schedule is preliminary and is presented to provide a general overview of the major items that would have to completed for such a project. It is not intended to be comprehensive but rather a starting point for consideration and discussion among the participating Institutes and Organizations.

Technical Evaluation of Proposed Ukrainian Radioactive Waste Processing Facility 



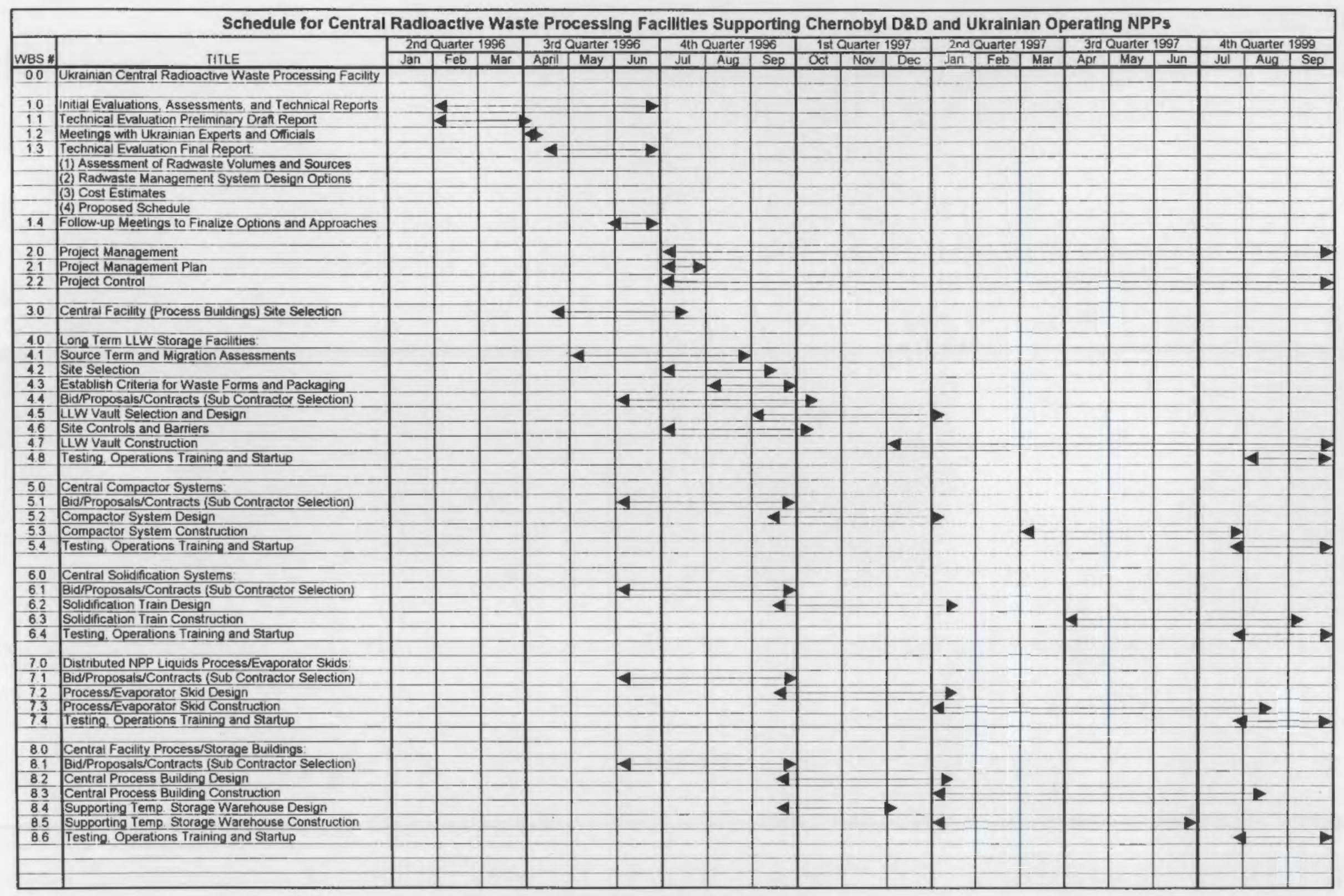




\subsection{Solid Waste Management Systems Options}

The types of solid waste generated at a NPP can be classified into four main groups: concentrated liquids (slurries such as evaporator bottoms), wet solids (resins and sorbents), dry solids (ash or dry resins) and contaminated trash (anti-contamination clothing, plastic, concrete, wood etc.) The discharge of the NPPs liquid radioactive waste systems and the solids can be processed at the central facility using treatment methods that may consist of segregation, additional volume reduction (such as incineration, compaction or super-compaction), solidification of liquids, wet solids and ash in concrete or bitumen followed by final packaging of the solids for storage and disposal.

The steps for solid waste management consist of waste collection, waste pretreatment and voiume reduction, solidification and mixing, and final package container handling storage and disposal. All of the solid waste options include the capital and operating costs associated with a compactor system to process the contaminated trash that is not solidified.

\subsubsection{Option 1 Description and Costs}

This is the conventional option where the solid wastes generated (concentrated liquids, resins or dry solids) are solidified in cement or other binding agents. Cement is often used in the U.S. because of its relatively low cost and stability, bitumen is used primarily in Europe. However, mixing of the waste stream with the solidification agent increases the volume of waste to be disposed. The volume increase ratio for solidification of concentrated liquids and ion-exchange resins is approximately 1.4 .

The capital equipment cost estimates for a centralized solidification system capable of handling the total estimated generation rates and volumes are in the range of $\$ 8,550,000$ to $\$ 51,340,000$. These estimates came from recently completed individual utility projects and Ref. [3] where solidification systems supporting a single unit are estimated at $\$ 990,000$ to $\$ 5,900,000$. The individual unit estimates were adjusted to account for the required capacity to service 15 Ukrainian power plants. Solidification units have a wide range of potential configurations including: in-line mixing, in-container mixing, batch, continuous, automatic drum stacking, etc. leading to the large range in cost estimates.

The yearly processing cost estimate for a centralized solidification system is $\$ 9,300,000$ based upon the processing costs per cubic meter found in Ref. [11]. The capital cost estimate for storage space for the operating NPP only is $\$ 93.000,000$ based upon the storage costs per cubic meter found in Ref. [11].

The capital equipment cost estimates for a centralized solids compactor system capable of processing the total estimated generation rates and volumes are in the range of $\$ 640,000$ to

Technical Evaluation of Proposed Ukrainian Radioactive Waste Processing Facility 
$\$ 2,560,000$. These estimates come from Refs. [ 3 and 11] where a compactor system supporting a single unit are estimated at $\$ 74,000$ to $\$ 295,000$. The individual unit estimates were adjusted to account for the required capacity to service 15 Ukrainian power plants and the decommissioning waste from three RBMK-1000s at Chemobyl.

The yearly processing cost estimate for a centralized solids compactor system for the operating NPPs is $\$ 8,570,000$ based upon the processing costs per cubic meter found in Ref. [11]. The yearly processing cost estimate for a centralized solids compactor system for the Chomobyl decommissioning waste is $\$ 9,050,000$ based upon the processing costs per cubic meter found in Ref. [11].

When evaluating the total present worth (in terms of total costs) for Option 1 it becomes clear that Option 2 is the preferred alternative in terms of minimizing total costs. Option 2 has a lower present worth (total cost), due to the fact that the yearly processing and storage costs are much higher for Option 1 (there is a greater volume of waste to process and store). This is true even though the initial capital equipment costs are higher for Option 2.

\subsubsection{Option 2 Description and Costs}

See the above discussion under Section 3.2 Liquid Waste Management Systems Options (Option 2).

\subsubsection{Option 3 Description and Costs}

Option 3 is the use of incineration technology at the central facility to process the resins, sludge. and combustible trash (often $50 \%$ to $80 \%$ of the total dry solids generated). Because this option cannot process evaporator bottoms (concentrated liquids), without the use of a dryer system, a solidification train is required to process the concentrated liquids. The solidification train is also required to solidify the resulting ash. In addition, a compactor system is required to compact the non-combustible trash and salts. Incineration systems are relatively expensive compared to the other available technologies with total system capital costs from Refs. [ 3 and 11] ranging from $\$ 13$ to $\$ 115$ million dollars. Because of the high costs of incineration systems, which are due primarily to the high initial capital cost and the high costs of operation, including scrubbing and filtering the exhaust gasses, only the capital costs are evaluated. Incineration systems, although commercially available, are not routinely used at commercial nuclear reactors and their use for the Ukrainian nuclear reactors is not recommended because of the high costs and technical concerns involved

In addition to the high costs of incineration, other technical concerns also limit the viability of an incineration systern. Incineration of intermediate level and above wastes would require shielding of the incinerator itself with provisions for remote operation throughout the process, limiting

Technical Evaluation of Proposed Ukrainian Radioactive Waste Processing Facility 
incineration to low-level wastes only. Segregation would be required to eliminate objects from the waste stream that are unsuitable for combustion such as: PVCs, high rubber content items, large metal objects, and explosion hazards. The feasibility of incinerating ion exchange resins is not well established and there are uncertainties in the areas of volume reduction effectiveness, corrosive attack, emissions generated, system complexity, long term effects and overall economics. For these reasons, an incineration system for general use is not recommended for the Ukrainian central radioactive waste processing facility. However, incineration systems can be developed for special processes if the economics prove viable and a specific need for an incineration system is identified.

\subsection{Options for Storage Facility and Central Shielded Process Building}

The storage facility and central process buildings should be designed, and constructed in conformance with acceptable standards and regulations. These standards and regulations can be summarized with one general and three specific performance objectives for any storage and radioactive waste process facility Ref. [3]. These performance objectives summarize those that have been established for U.S. facilities. Given that the proposed storage and process facility is to be located in Ukraine, near the destroyed unit at Chernobyl, all of these performance objectives may or may not be directly applicable.

The general performance objective addresses the site-specific barrier system that must be designed for long term safe storage performance through:

(1) detailed engineering design of the proposed structure;

(2) developed operational procedures;

(3) criteria for the waste forms and packaging to be stored;

(4) consideration and use of the natural characteristics of the site; and

(5) established controls for site land use.

The three specific performance objectives include:

(1) protection of the ground water (requires consideration of local geology and hydrology);

(2) protection against any inadvertent intruder (requires consideration of local natural resources, population distribution, and existing land use patterns); and

(3) provisions to ensure safety during operation of the storage facility (requires consideration of ALARA, waste routing. waste packaging and operator/administrative controls).

There are many design provisions that must be considered to meet the above performance objectives. Design provisions include but are not limited to: ensuring structural stability; the use of curbs and drains to contain spills; proper material selection; precluding release pathways;

Technical Evaluation of Proposed Ukrainian Radioactive Waste Processing Facility 
collecting drainage; proper shielding configurations; fire protection; and corrosion allowances.

The storage facility options include:

(1) Temporary Storage in Warehouse Structures

(2) Shallow Land Burial (Earth Mounded Bunkers and Trenches)

(3) Shallow Land Burial (Earth Mounded Concrete Bunkers)

(4) Above Ground Vaults

(5) Below Ground Vaults

(6) Mined Cavities (New mined cavities would be overly expensive but existing dry limestone or salt mines might be feasible. Coal mines are prohibited due to corrosive and potentially explosive environments.)

Many different materials have been used to construct storage vaults and no constraints should be placed on material selection or shape of the storage vaults as long as the performance objectives can be met.

The structure costs per $m^{\wedge} 2$ for storage facilities and for shielded buildings and warehouses for a central process facility are taken from Refs. [3 and 11].

Structure or Facility

Radioactive Waste Storage Facility

Central Process Building (shielded)

Warehouse (shielded)
Typical Cost Range per $\mathrm{m}^{\wedge} 2$

$\$ 4,900-\$ 10,600 / \mathrm{m}^{\wedge} 2$

$\$ 4,900-\$ 8.200 / \mathrm{m}^{\wedge} 2$

$\$ 850-\$ 1,700 / \mathrm{m}^{\wedge} 2$ 


\section{References}

1. Letter from T.R. Lash; Director, DOE Office of Nuclear Energy, Science and Technology, to Mr. N. R. Nigmatullin; Acting Chairman Ukrainian State Committee on Nuclear Power Utilization, Dated January 5, 1996.

2. Intemational Atomic Energy Agency (IAEA). 1994. Assessment and Comparison of Waste Management System Costs for Nuclear and Other Energy Sources. IAEA Technical Reports Series No. 366, Vienna.

3. Moghissi AA, HW Godbee, SA Hobart, eds. 1986. Radioactive Waste Technology. The American Society of Mechanical Engineers, New York.

4. Wild RE, OI Oztunali, JJ Clancy, CJ Pitt, ED Picazo, 1981. NUREG/CR-1759 Data Base for Radioactive Waste Management. Prepared for the U.S. Nuclear Regulatory Commission.

5. Ryzhkova V, L Khamyanov, S Hubetsov, and V Zimin, 1993. Approach to Radwaste Management at Russian NPPs. Radiation Security and Chemical Technology Department Research Institute for Nuclear Power Plant Operation, Moscow, Russia. Presented at the International Conference on Nuclear Waste Management and Environmental Remediation, September 5-11, 1993, Prague, Czech Republic

6. Antonov BV, 1994. Operational Experience of Russian Nuclear Power Plants. Proceedings of an International Conference on the Nuclear Power Option Organized by the International Atomic Energy Agency and Held in Vienna, 5-8 September, 1994.

7. Nilsen, Thomas and N. Bøhmer, 1994. Bellona Report Volume 1. Sources of Radioactive Contamination in Murmansk and Arkhangel'sk Countries. Published by the Bellona Foundation, Oslo, Norway

8. Grundfelt B, B Lindbom, 1994. Radioactive Waste in the Russian Federation. Published by the Swedish Radiation Protection Institute

9. ANSI/ANS - 55.6 - 1993, Liquid Radioactive Waste Processing System for Light Water Reactor Plants. American Nuclear Society

10. Umanets MP, 1994. Present Status of Nuclear Power in Ukraine and Prospects for its Development. Proceedings of an Intemational Conference on the Nuclear Power Option Organized by the International Atomic Energy Agency and Held in Vienna, 5-8

Technical Evaluation of Proposed Ukrainian Radioactivc Waste Processing Facility

\section{R. 1}


September, 1994.

11. Clark R, R Knudson, F Sciacca, G Simion, J Nemergut, September 1988. NUREG/CR4555 Generic Cost Estimates for the Disposal of Radioactive Wastes. Prepared for the U.S. Nuclear Regulatory Commission.

12. ANSU/ANS - 55.1 - 1992, Solid Radioactive Waste Processing System for Light-WaterCooled Reactor Plants. American Nuclear Society.

13. ANSU/ANS - 55.4 - 1993, Gaseous Radioactive Waste Processing Systems for Light Water Reactor Plants. American Nuclear Society.

14. Pravda Ukrainy, February 19, 1991. Zaporozhye Nuclear Station's Radioactive-Waste Disposal Process. 34(14799):3, cols. 1-5.

15. Moscow Interfax, November 14, 1994. German Firm to Aid Solve Radioactive Waste Disposal Problem.

16. Letter from VD Chebrov; Head of the GOSKOMATOM Division for Regulations to RO Gates and A Glukhov; Battelle PNNL, Dated March 14, 1996.

17. Ukraine Ministry of Environmental Safety, Kiev 1995. Status Report, Nuclear and Radiation Safety in Ukraine 1994. Nuclear Regulatory Administration.

18. Joint Parallel Russian-American Study of Nuclear Power Development Alternatives in Russia (SIARYAE/INPAS). 1994. Assessments of the Technical and Economic and Socio-Economic Costs of Early Decommissioning of First-Generation Nuclear Power Plants with VVER-440 and RBMK-1000 Reactors.

19. U.S. Code of Federal Regulations, January 1, 1995. IO CFR Part 6l, Licensing Requirements for Land Disposal of Radioactive Waste. U.S. Nuclear Regulatory Commission.

20. Bogdan I, H Mikolaychuk. N Steinburg, June 13-18, 1993. Performances of Existing Storage and Disposal Facilities in $30 \mathrm{~km}$ Zone of Chornobyl NPP. UKrSCNRS, Kiev, Ukraine. Presented at Safewaste 93, Avigon, France.

21. Sobotovich EV, GN Bondarenko, 1994. Specific Character of Radioactive Waste in the Exclusion Zone of the Chornobyl NPP. National Academy of Sciences of Ukraine. Presented at SPECTRUM 94, Atlanta, Georgia, August 14-18, 1994.

Technical Evaluation of Proposed Ukrainian Radioactive Waste Processing Facility 
22. Waight $\mathrm{P}$, et al, November 1995. Chernobyl Ten Years on Radiological and Health Impact An Appraisal by the NEA Committee on Radiation Protection and Public Health. Nuclear Energy Agency, Organization for Economic Co-Operation and Development.

23. Kholosha VI, et al, 1996. Chornobyl: Ten Years of Overcome. The Ukrainian Ministry for Chomobyl Affairs.

24. Borovol A, April 1996. The Sarcophagus What Do We Know? What Should We Do? Nuclear Engineering International.

25. Sich AR, April 1996. The Chernobyl Active Phase Why the "Official View" is Wrong. Nuclear Engineering International.

26. Kupny VI, April 1996. Chernobyl NPPs Shelter Site Yesterday, Today and Tomorrow. Production Association P/O Chernobyl NPP, Ukraine.

27. Maslyakov GA, VM Zeinichenko, VN Pukhalskiy, April 1996. Report on Issues Concerning the Construction of a Ukrainian Central Radioactive Waste Processing Facility. Ukrainian Scientific Research and Design Institute for Industrial Technology.

28. Konzek GJ, RI Smith, MC Bierschbach, PN McDuffie, November 1995. NUREG/CR5884 (PNL-8742) Revised Analyses of Decommissioning for the Reference Pressurized Water Reactor Power Station, Vols I \& 2. Prepared for the U.S. Nuclear Regulatory Commission.

Technical Evaluation of Proposed Ukrainian Radioactive Waste Processing Facility R.3 


\section{Appendix A: Computer Models used in this Evaluation (Radstat1.xls and Ukrcalc1.med)}




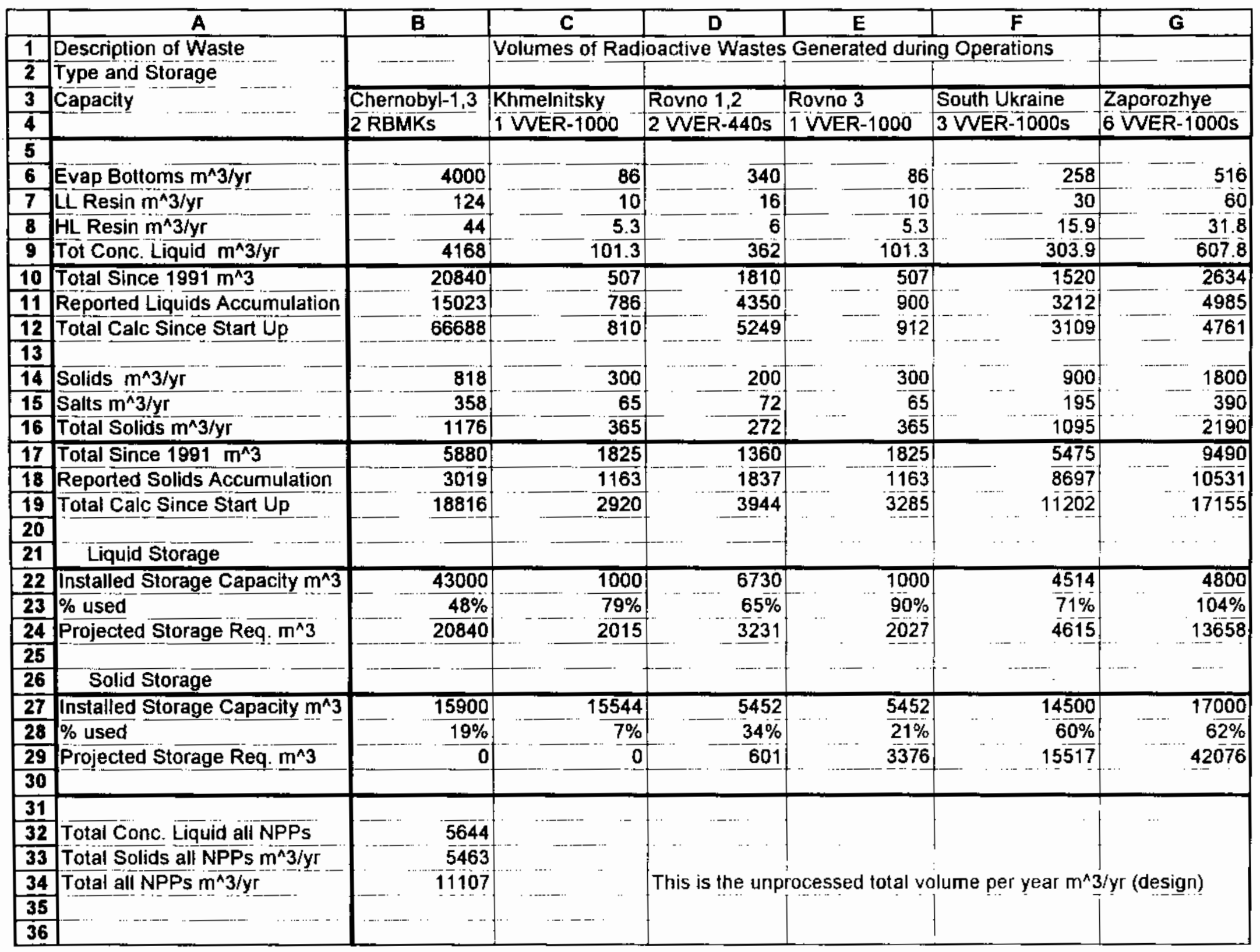




\begin{tabular}{|c|c|c|c|c|c|c|c|}
\hline & A & B & c & D & E & $\mathbf{F}$ & G \\
\hline \multicolumn{8}{|l|}{37} \\
\hline \multicolumn{8}{|l|}{38} \\
\hline 39 & & & \multirow{2}{*}{\multicolumn{5}{|c|}{ Estimated Waste Volumes from Decommissioning and Dismantaling Activities }} \\
\hline \multicolumn{3}{|c|}{ - _- } & & & & & \\
\hline 41 & & \multirow{2}{*}{\multicolumn{6}{|c|}{$\begin{array}{l}\text { fFor purposes of estimating volumes the following assumptions were made for material packing } \\
\text { densities: Concrete } 150 \mathrm{lbm} / \mathrm{ft}^{\wedge} 3, \text { Scrap } 1.6 \mathrm{~g} / \mathrm{cm}^{\wedge} 3 \text { (avg.). Equipment } 0.05 \mathrm{lbm} / \mathrm{in}^{\wedge} 3 \text { (avg.). }\end{array}$}} \\
\hline$\frac{42}{43}$ & $-\begin{array}{llll}- & \cdots & \ldots & \ldots\end{array}$ & & & & & & \\
\hline 44 & \multirow{2}{*}{ Waste Type } & \multirow[b]{2}{*}{ RBMK-1000 } & \multirow{2}{*}{$\begin{array}{l}\text { Metric Tons } \\
\text { WER- } \overline{4} \overline{40}\end{array}$} & \multirow[b]{2}{*}{ WER-1000 } & \multirow[b]{2}{*}{ RBMMK-1000 } & $m^{\wedge} 3$ & \multirow[b]{2}{*}{ WER-1000 } \\
\hline 45 & & & & & & WER-440 & \\
\hline 46 & Concrete & 36000 & 3250 & 12000 & 14942 & $\begin{array}{l}1349 \\
318\end{array}$ & 4981 \\
\hline 47 & Scrap & 2500 & 500 & 900 & 1588 & \multirow{2}{*}{$3 \frac{318}{3379}$} & \multirow{2}{*}{$\begin{array}{rr}-572 \\
-4328\end{array}$} \\
\hline 48 & Equipment & 12106 & 4685 & 6000 & 8732 & & \\
\hline 49 & 30 yrs of Operations Solids & & & & 17640 & 7080 & \multirow{2}{*}{$\frac{10950}{4341}$} \\
\hline 50 & 30 yrs of Solidified Liquids & & & & 89314 & $7 \overline{757}$ & \\
\hline 51] & OOther Solids (10\%) & & & & 1764 & $\overline{7} \overline{0} \overline{8}$ & 1095 \\
\hline 52 & Other Solidified Liquids (10\%) & & & & 8931 & $77 \overline{6}$ & $4 \overline{34}$ \\
\hline 53 & Totals & & & & $1 \overline{4} 29 \overline{1} 2$ & 21367 & 26701 \\
\hline 54 & -.... & & & & & & \\
\hline 55 & ( & & & Total Estimatec & d D\&D Wastes fo & or Each NPP Site $\mathrm{m}$ & $n^{\wedge} 3$ \\
\hline 56 & Waste Type & Chernobyl 1-3 & Khmelnitsky & Rovno 1,2 & Rovno 3 & South Ukraine & Zaporozhye \\
\hline 57 & & 3 RBMKS & 1 WER-1000 & 2 VER-440s & 1 WER-1000 & 3 WER-1000s & 6 WER-1000s \\
\hline 58 & Concrete & 44827 & 4981 & 2698 & 4981 & 14942 & 29885 \\
\hline 59 & Scrap & 4763 & 572 & 635 & 572 & 1715 & $3 \overline{42} \overline{9}$ \\
\hline 60 & Equipment & 26197 & 4328 & $6 \overline{759}$ & 4328 & $12 \overline{8} \overline{8}$ & $2596 \overline{7}$ \\
\hline 61 & 30 yrs of Operations Solids & 28224 & 10950 & $1416 \overline{0}$ & 10950 & 32850 & 65700 \\
\hline 62 & 30 yrs of Solidified Liquids & 100032 & 4341 & 15514 & 4341 & 13024 & 26049 \\
\hline 63 & Other Solids $(10 \%)$ & 5292 & 1095 & 1416 & 1095 & 3285 & 6570 \\
\hline 64 & Other Solidified Liquids ( $10 \%)$ & 26794 & 434 & 1551 & 434 & 1302 & 2605 \\
\hline 65 & Totals $\mathrm{m}^{\wedge} 3$ & 236129 & 26701 & 42733 & 26701 & 80102 & 160204 \\
\hline 66 & & & & & & & \\
\hline 67 & Total 30 yrs of Ops Solids. & 162834 & & Total Concrete & all NPPS & & 102314 \\
\hline 68 & Total 30 yrs of Ops Solidified li & 163302 & & Total Scrap all & NPPS & & 11684 \\
\hline 69 & Total 30 yrs of Ops all NPP & 326136 & & Total Equipmer & nt all NPPs & & 80562 \\
\hline 70 & -..... & $\ldots . . .$. & & Total Other Sol & tids $(10 \%)$ all NP & & 18753 \\
\hline 71 & 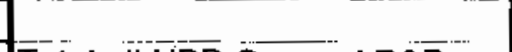 & & & Total Other Sol & Lidified Liquids (1 & $0 \%$ all NPPS & 33121 \\
\hline 72 & Total all NPP Ops and D\&D & 572570 & & Total D\&O Was & ste all NPPS & & $24 \overline{6} \overline{4} 34$ \\
\hline
\end{tabular}




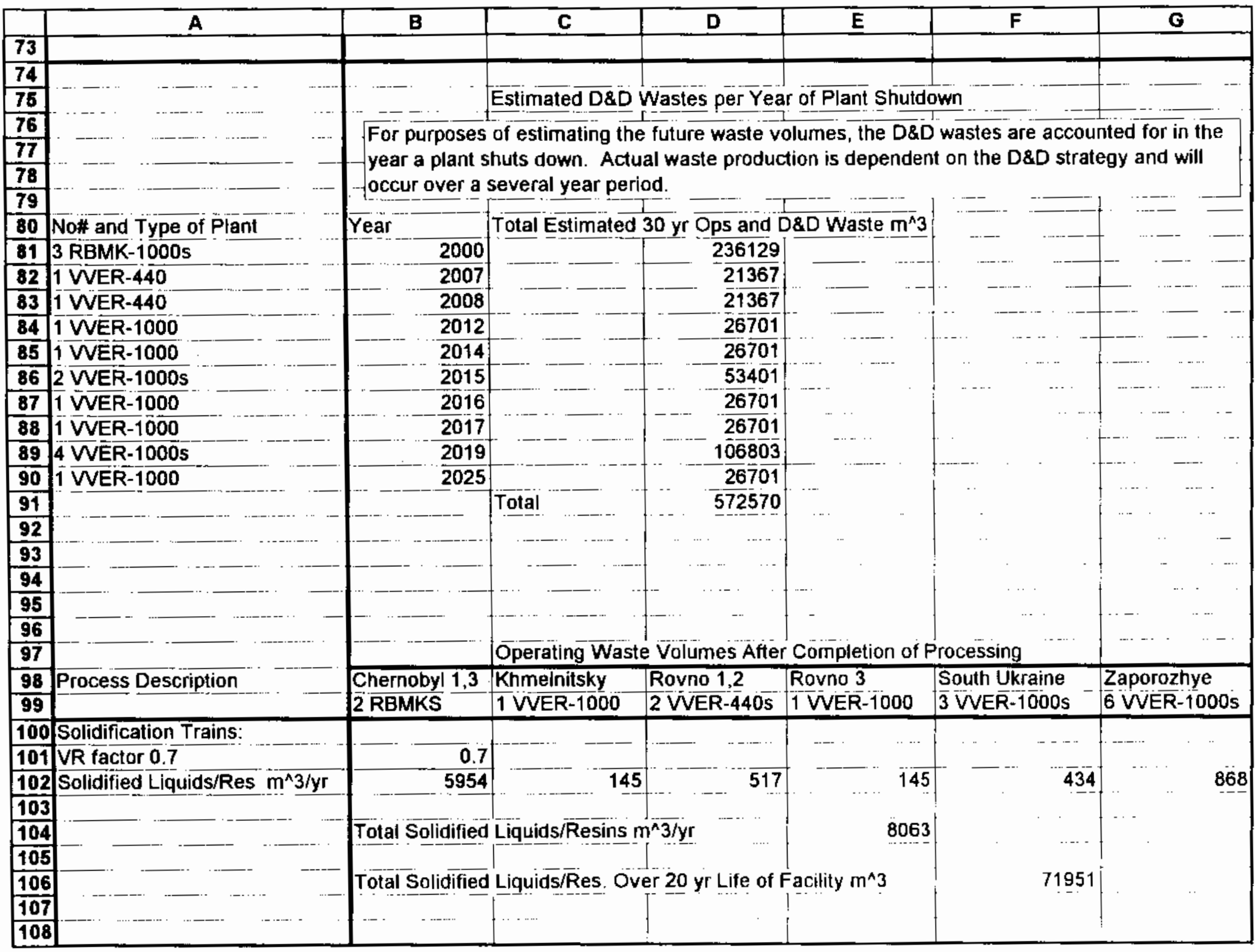




\begin{tabular}{|c|c|c|c|c|c|c|c|}
\hline & A & B & C & D & E & $\mathbf{F}$ & $\mathbf{G}$ \\
\hline 109 & Standard Compactor: & & & & & & \\
\hline 110 & VR factor 2.3 (2.0 for Salts) & 2.3 & $\ldots$ & VR factor for $\mathrm{C}$ & utting and $H$ and $F$ & Packing & - \\
\hline 111 & $47 \%$ of Solids are compactible & $\quad 0 . \overline{4}$ & & & & & - n \\
\hline 112 & $53 \%$ are Non-Compactible & 0.53 & & & & & \\
\hline 113 & Compacted Solids $\mathrm{m}^{\mathrm{i}} 3 / \mathrm{yr}$ & 346 & 94 & 77 & 94 & 281 & 563 \\
\hline 114 & Non-Compacted Solids $m^{\wedge} 3 / y r$ & 723 & 265 & 177 & $2 \overline{65}$ & 795 & 1590 \\
\hline 115 & Totals $\mathrm{m}^{\wedge} 3 / \mathrm{yr}$ & 1069 & 359 & 254 & $3 \overline{5}$ & 1076 & 2153 \\
\hline 116 & $\ldots$ & & & & & & \\
\hline 117 & & Total Processec & Solids $m^{\wedge} 3 / y r$ & $5 \overline{269}$ & & & \\
\hline 118 & ..... . & & & & & & - \\
\hline 119 & & Total Processec & Solids Over 20 & yr Life of Facilit & $y m^{\wedge} 3$ & 89351 & \\
\hline 120 & & & & & & & \\
\hline 121: & Super Compactor: & & & & & & \\
\hline 122 & VR factor 8.7 (2.0 for Salts) & 8.7 & 2 & VR factor for $\mathrm{C}$ & utting and Hand $F$ & Packing & 0.8 \\
\hline 123 & $47 \%$ of Solids are Compactible & 0.47 & & & & & \\
\hline 124 & $53 \%$ are Non-Compactible & 0.53 & & & & & \\
\hline 125 & Compacted Solids $m^{\wedge} 3 / y r$ & 223 & 49 & 47 & 49 & 146 & 292 \\
\hline 126 & Non-Compacted Solids $\mathrm{m}^{\wedge} 3 / \mathrm{yr}$ & 542 & 199 & 133 & 199 & 596 & 1193 \\
\hline 127[ & Totals $\mathrm{m}^{\wedge} \mathbf{3} / \mathrm{yr}$ & $76 \underline{5}$ & 247 & 179 & 247 & 742 & 1485 \\
\hline 128 & & & & & & & \\
\hline 129 & & Total Processec & Solids $\mathrm{m}^{\wedge} 3 / \mathrm{yr}$ & 3666 & & & \\
\hline 130 & & & & & & & \\
\hline 131 & - & Total Processe & Solids Over 20 & yr Life of Facilit & $y m^{\wedge} 3$ & 61852 & 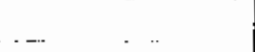 \\
\hline 132 & - & & & & & & $\cdots$ \\
\hline 133 & & & & & & & \\
\hline 134 & Advanced Mobile & & & & & & \\
\hline 135 & Liquid Evaporator/Solidification & & & & & 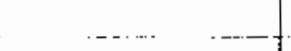 & . \\
\hline 136 & VR factor 6.0 (for Conc Liq.) & 6 & & & & & \\
\hline 137 & VR factor 2.0 (for Resins) & 2 & & & & & \\
\hline 138 & Evap/Solid Conc Liquids $m^{\wedge} 3 / y$ & 667 & 14 & 57 & 14 & 43 & 86 \\
\hline 139 & Evap/Solid Résins $m^{\wedge} 3 / y r$ & & 8 & 11 & & 23 & $\overline{4} \overline{6}$ \\
\hline 140 & Totals $\mathrm{m}^{\wedge} 3 / \mathrm{yr}$ & 751 & & & & & $13 \overline{2}$ \\
\hline 141) & & & & & & & \\
\hline 142 & --.. & Total Processe & 1 Liquids $\mathrm{m}^{\wedge} 3 / \mathrm{yr}$ & 1060 & & & \\
\hline 143 & $-\ldots$ & & & & & & \\
\hline 144 & & Total Processe & Liquids Over 20 & yr Life of Facili & ity $m^{\wedge} 3$ & $9943 !$ & \\
\hline
\end{tabular}




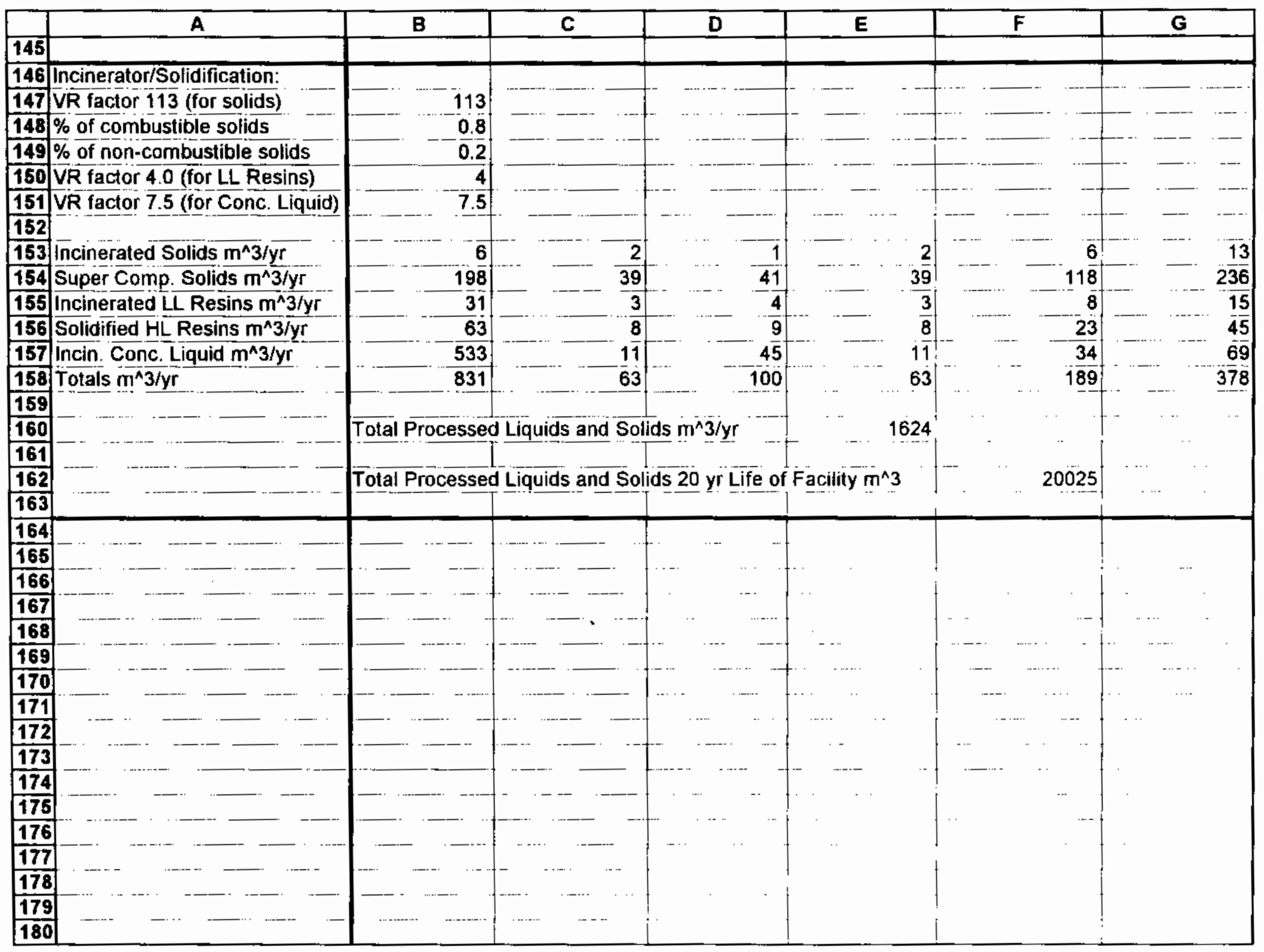


Calculational Models for the Technical Evaluation of a Proposed Central Radioactive Waste Processing Facility to be Located in Ukraine

The purpose of these calculations are to establish a technical basis for evaluating the Ukrainian proposal for a cenural radioactive waste facility. The data is mainly based upon publicly available literature. In addition, specific data was oblained from the Ukrainian State Committee on Nuclear Power Utilization (GOSKOMATOM). The curent volumes. generation rates, available storage and processing rates for the Ukrainian nuclear power plants and the proposed processing facility are evaluated. Also, estimates of the future radioactive waste volumes, generation rates and processing rates are evaluated. In addition, the estimated costs for a processing facilicy capable of handiing the volumes of radioactive waste described are evaluated.

Define descriptive variables for the Ukrainian Power Plants:

N $1=11 \quad$ Number of VVER-1000 Plants Curently Operating

Capl $=1000 \quad$ MWe

N2 = $2 \quad$ Number of VVER-440 Plants Currently Operating

Cap2 $=440 \quad$ MWe

N3 = 2 Number of RBMK-1000 Plants Currently Operating

Cap3 $=1000 \quad M W_{c}$

Define Conversion Factors:

\begin{tabular}{|c|c|c|c|}
\hline $\mathrm{Cmg}=264.17$ & $\operatorname{gal}($ us $) / \mathrm{m}^{\wedge} 3$ & $\mathrm{Cmf}=35.31$ & $\mathrm{ft}^{\wedge} 3 / \mathrm{m}^{\wedge} 3$ \\
\hline$C \operatorname{Lm}=3.785412 \cdot 10^{-3}$ & $m^{\wedge} 3 /$ gal(us) & $\mathrm{Cfm}=0.0283$ & $m^{\wedge} 3 / \mathrm{A}^{\wedge} 3$ \\
\hline $\mathrm{Cmy}=1.3079$ & $y d^{\wedge} 3 / m^{\wedge} 3$ & & \\
\hline$C_{y m}=0.7645549$ & $\mathrm{~m}^{\wedge} 3 / \mathrm{y}^{\wedge} 3$ & & \\
\hline
\end{tabular}

Define Radioactive Waste Generation Rates:

For the VVER-1000 Plants
EB1 : $86 \quad \mathrm{~m}^{\wedge} 3 / \mathrm{yr}$ of Evaporator Botioms
TS $190 \quad$ tons/yT of Total Salt
LR1 $10 \quad \mathrm{~m}^{\wedge} 3 / \mathrm{vr}$ of Low-Level Resin Beads (Sorbents)
HR $15.3 \quad \mathrm{~m}^{\wedge} 3$ 丸 $\mathrm{r}$ of High-Level Resin Beads (Sorbents)
$\mathrm{SG} 1 \quad 300 \quad \mathrm{~m}^{\wedge} 3 / \mathrm{yr}$ of Solids
LS $1=1800 \quad \mathrm{~m}^{\wedge} 3$ of Liquid Storage Capacity LLW and LW 


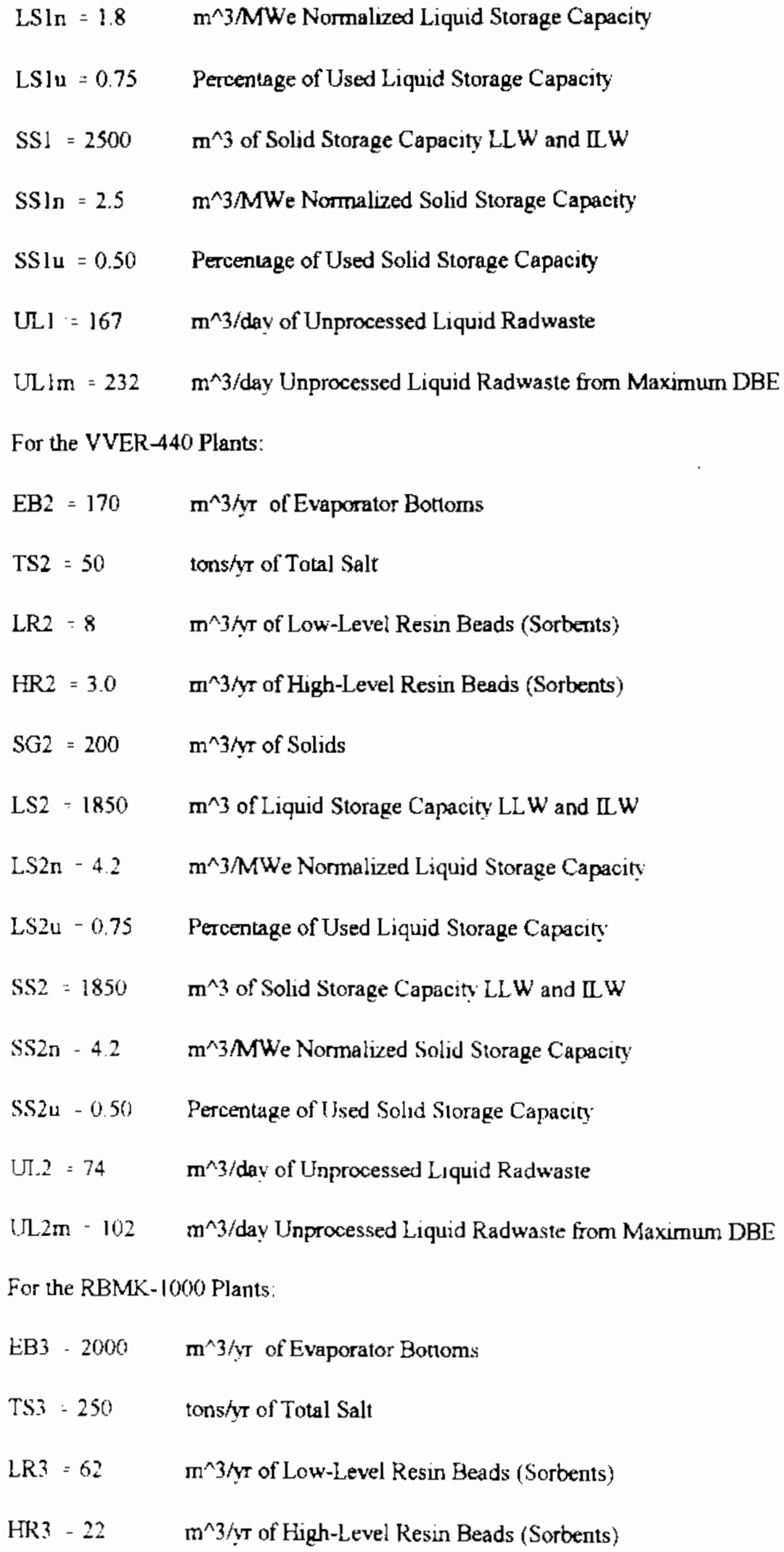




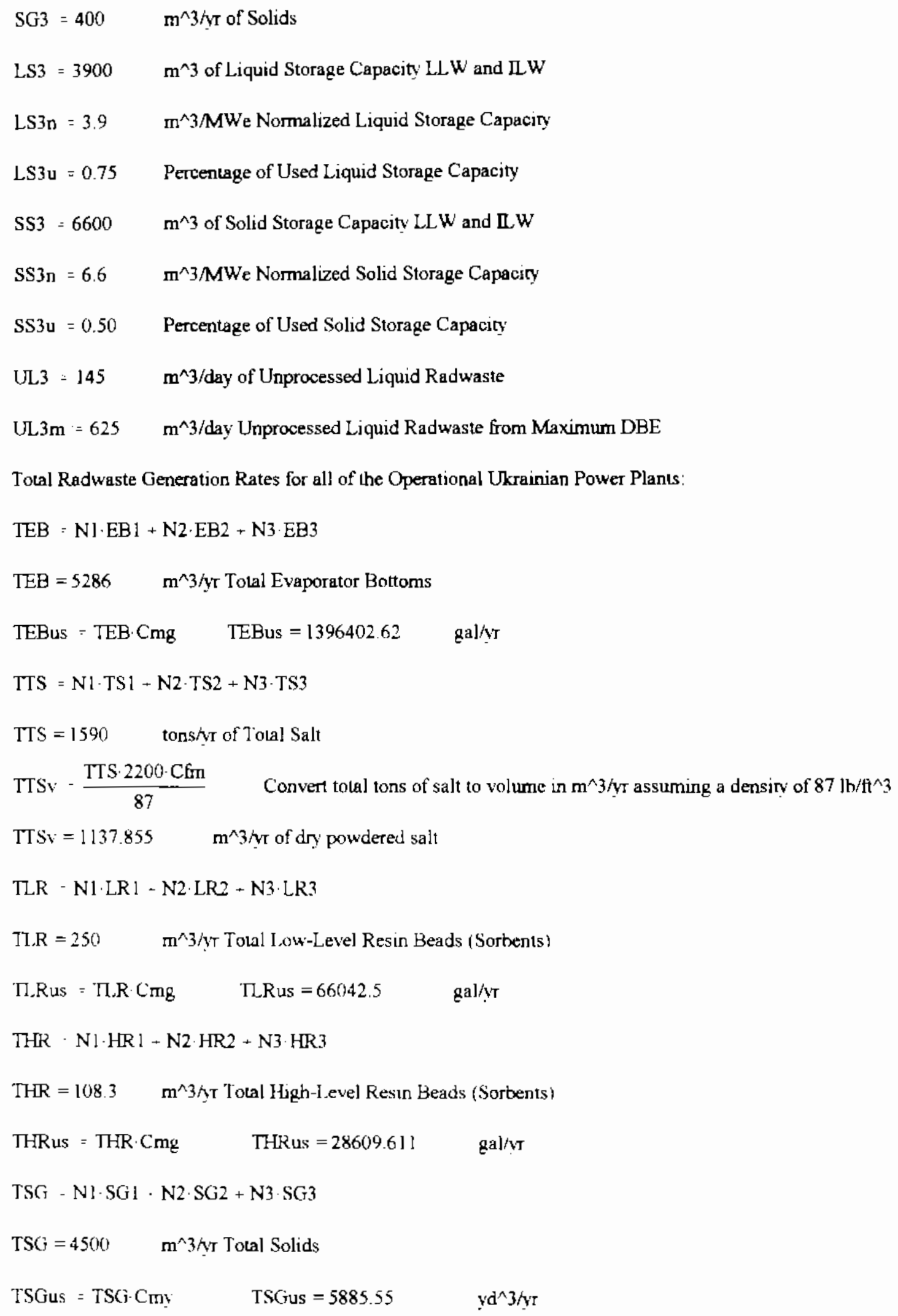


$T U L=N 1 \cdot U L 1+N 2 \cdot U L 2+N 3 \cdot U L 3$

$\mathrm{TUL}=2275 \quad \mathrm{~m}^{\wedge} 3 /$ day Tocal Unprocessed Liquid Radwaste

TULus $=\pi$ U. $\mathrm{Cmg} \quad$ TULus $=600986.75 \quad \mathrm{gal} / \mathrm{day}$

TULm $=\mathrm{N} 1 \cdot \mathrm{UL} 1 \mathrm{~m}+\mathrm{N} 2 \cdot \mathrm{UL} 2 \mathrm{~m}+\mathrm{N} 3 \cdot \mathrm{UL} 3 \mathrm{~m}$

TULm $=4006 \quad m^{\wedge} 3 /$ day Total Unprocessed Liquid Radwaste from Maximum DBE

TULmus $=$ TULm $\cdot \mathrm{Cmg} \quad$ TULmus $=1058265.02 \quad \mathrm{gal} / \mathrm{day}$

Calculate the tolal amount of waste to be generated from decommissioning of 3 RBMKs at Chemobyl:

Concrete:

$\mathrm{DC}=\frac{3 \cdot 36000 \cdot 2200 \cdot 0.0283}{150} \quad \mathrm{DC}=44827.2 \quad \mathrm{~m}^{\wedge} 3$ of concrete with a detsity of $150 \mathrm{lb} / \mathrm{A}^{\wedge} 3$

Scrap

$\mathrm{DS}=\frac{3 \cdot 2500 \cdot 1016}{1600} \quad \mathrm{DS}=4762.5 \quad \mathrm{~m}^{\wedge} 3$ of scrap with an average true density of $1.6 \mathrm{~g} / \mathrm{cm}^{\wedge} 3$

Equipment:

$\mathrm{DE}-\frac{3 \cdot 15000 \cdot 2200}{0.30 \cdot 6.1 \cdot 10^{4}} \quad \mathrm{DE}=5409.836 \quad \mathrm{~m}^{\wedge} 3$ of equipment with steel density of $0.30 \mathrm{lb} / \mathrm{in}^{\wedge} 3$

Other $(12 \%$ of Waste Generated from 30 yrs of Operation)

$\mathrm{DOs}=3 \cdot 12000 \cdot 0.12 \quad \mathrm{DOs}=4320 \quad \mathrm{~m}^{\wedge} 3$ of solid wastes

$\mathrm{DOb}=3 \cdot 22500 \cdot 0.12 \quad \mathrm{DOb}=8100 \quad \mathrm{~m}^{\wedge} 3$ of biturnenized wastes

Define Capital Cost Ranges for the Options. Inchude Initial Equipment Capilal Costs (c), Processing (p), and Storage (s) Costs: Ranges are indicated with Low (L) and High (H). Project Life is esimated at 20 years.

The combuned real discount and inlation rate is assumed to be

la $=.05$

$n=20$

PA $-\frac{(1-\mathrm{Ia})^{\mathrm{n}}-1}{\mathrm{Ia} \cdot(1+1 \mathrm{la})^{\mathrm{n}}} \quad \mathrm{PA}=12.462 \quad$ Uniform Series, Present Worth Factor 
Opition !

This is a centralized solidification system for liquids with a compactor system to process the soiids.

The estimated number of solidification system trains required to process the total Ukrainian waste suream will be used to factor up the equipment capilal costs. An indusiry standard solidification system capaciry of 3000 drumshy or 653 $\mathrm{m}^{\wedge} 3 / \mathrm{yr}$ was assurned.

PRl = $653 \quad \mathrm{~m}^{\wedge} 3 / \mathrm{yT}$

$\mathrm{E} 1=\frac{\mathrm{TEB}+\mathrm{TLR}+\mathrm{THR}}{\mathrm{PR}]}$

$\mathrm{Fl}=8.644$

Initjal Capital Costs (Low and High) in Present Dollars for a Solidification System

$\mathrm{ClcL}=\mathrm{F} 1 \cdot 500000 \cdot(1+\mathrm{Ia})^{14} \quad \mathrm{ClcL}=8556912.654$

$\mathrm{ClcH}=\mathrm{F}] \cdot 3000000 \cdot(\mathrm{I}+\mathrm{Ia})^{14} \quad \mathrm{ClcH}=5.134 \cdot 10^{7}$

Annual processing costs for a solidification system given in yearly costs and converted to total present costs for $n$ years of operation.

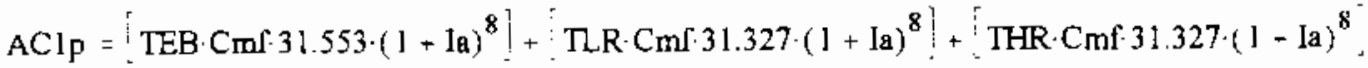

$\mathrm{ACIp}=9286784.057 \quad$ Yearly Processing Cost

PWClP - PA AClp

PWClp $=1.157 \cdot 10^{8} \quad$ Present Worth of yearly processing costs over $n$ years

Capital cost of storage building to store the solidified waste

Cls $={ }^{\prime} \mathrm{Cm}\left[15.798 \cdot(1-\mathrm{Ia})^{8} \mid \cdot \mathrm{n} \cdot(\mathrm{TEB}+\mathrm{TLR}+\mathrm{THR})\right.$

$C I s=9.3014 \cdot 10^{7} \quad$ Capital Cost of Storage Building

Initual capical costs Low and High in present dollars for a typical Compactor System (Required for all options in order to process the solid wastes and dry saits generated). The capital costs for a compactor system are increased by a factor that accounts for the total compactible material that must be processed for all of the Ukrainian NPPs and Chemobyl decommissioning. The assumed process rate is taken from a counpactor designed for a single $1000 \mathrm{Mwe}$ PWR which must compact approxımately $400 \mathrm{~m}^{\wedge} 3 / \mathrm{yr}$. The compactible waste from Chemobyl decommissioning is assumed to occur and be processed and stored over a 20 year period. In addition the assumption is made that $47 \%$ of the solids are compactible and $53 \%$ are noncompactible.

CinpacRate $=400 \quad$ Assumed single unit compactor process rate $\mathrm{m}^{\wedge} 3 / \mathrm{yT}_{\mathrm{T}}$

$F C=\frac{0.47 \cdot \mathrm{TSG}+\mathrm{TTSv}+\frac{0.47 \cdot \mathrm{DS}}{20}+\frac{0.47 \cdot \mathrm{DOS}}{20}}{\text { CmpucRate }}$ 
$\mathrm{FC}=8.666$

Capital cost of compactor system

$\mathrm{CccL}=\mathrm{FC} \cdot 50000 \cdot(\mathrm{I}+\mathrm{Ia})^{8} \quad \mathrm{CccL}=640161.853$

$\mathrm{CccH}=\mathrm{FC} \cdot 200000 \cdot(1+\mathrm{Ia})^{8} \quad \mathrm{CccH}=2560647.413$

Assuming the dry salts will be processed in the compactor system, and the dry powder salt density is $87 \mathrm{lb} / \mathrm{t}^{\wedge} 3(1.4$ $\left.\mathrm{g} / \mathrm{cm}^{\wedge} 3\right)$ and a compacted density of $168 \mathrm{Jb} / \mathrm{A}^{\wedge} 3\left(2.7 \mathrm{~g} / \mathrm{cm}^{\wedge} 3\right)$. The volumes of dry salts to be processed are then found to be:

VTSd $-\frac{\text { TTS } 2200 \cdot \mathrm{Cfn}}{87}$

VTSd $=1137.855$

$m^{\wedge} 3 / y r$ of dry powdered salt

VTSc $=\frac{\text { TTS } 2200 \cdot \operatorname{Cfn}}{168}$

$\mathrm{VTSc}=589.246 \quad \mathrm{~m}^{\wedge} 3 / \mathrm{yr}$ of dry compacted salt

For the compactors the annual processing costs are given in yearly cosis and converted to total present costs for $n$ years of operation. Assume $47 \%$ of the solids are compatible and $53 \%$ are noncompactable, and all of the dry salt is compacted. The processing costs for decommissioning of 3 RBMKs are assumed to occur over $20 \mathrm{yrs}$ and are calculated separately from the processing and storage costs for the operating NPPs.

$$
\begin{aligned}
& \mathrm{ACcp}=0.47 \cdot \mathrm{TSG} \cdot \mathrm{Cmf} 5.555 \cdot(1+\mathrm{Ia})^{8} ! \cdot\left[0.53 \cdot \mathrm{TSG} \cdot \mathrm{Cmf} \cdot 62.584 \cdot(1+\mathrm{Ia})^{8}{ }_{1} \ldots\right. \\
& + \text { VTSc Cmf } 5.555(1+\mathrm{Ia})^{8}
\end{aligned}
$$

$\mathrm{AC}_{\mathrm{cP}}=8570572.525 \quad$ Yearly Processing Costs for Operating NPPs

$$
\begin{aligned}
\text { ACdecomp }= & \frac{D C}{20} \operatorname{Cmf} 62.584 \cdot(1+\mathrm{Ia})^{8}+\frac{0.47 \cdot \mathrm{DS}}{20} \operatorname{Cmf} 5.555 \cdot(1+\mathrm{Ia})^{8} \ldots \\
& +\frac{0.53 \cdot \mathrm{DS}}{20} \operatorname{Cmf} 62.584 \cdot(1+\mathrm{Ia})^{8}+\frac{\mathrm{DF}}{20} \operatorname{Cmf} 62.584 \cdot(1+\mathrm{Ia})^{8} \ldots \\
& +\frac{0.47 \cdot \mathrm{DOS}}{20} \cdot \operatorname{Cmf} 5.555(1+1 \mathrm{la})^{8}-\frac{0.53 \cdot \mathrm{DOS}}{20} \cdot \operatorname{Cmf} 62.584 \cdot(1+\mathrm{Ia})^{8}
\end{aligned}
$$

ACdecomp $=9048730.436 \quad$ Yearly Processing Costs for Decornmissionng Waste from 3 RBMKs

$\mathrm{PWC} \mathrm{CP}=\mathrm{PA} \cdot \mathrm{AC} \mathrm{cp}+\mathrm{PA} \cdot \mathrm{ACdecomp}$

PWCep $=2.196 \cdot 10^{8} \quad$ Present Worth of Yearly Processung Costs over n Years (Compactible and Non-Compactible Waste)

The capital costs for a storage building for the compactor output are estimated using the tocal volumes of waste to be stored including those for operating NPPs and the decornmissioning waste from 3 RBMKs. 


$$
\begin{aligned}
& \text { Ccs }-0.47 \cdot \text { TSG } n \cdot \operatorname{Cmf} \cdot 2.745 \cdot(1+\text { Ia })^{8} !+\left(0.53 \cdot \text { TSG } n \cdot \operatorname{Cmf} 25.469 \cdot(1+1 a)^{8^{7}} \ldots\right. \\
& + \text { VTSen } n \cdot \operatorname{Cmf} 2.745 \cdot(1-\mathrm{la})^{8} \text { ! }
\end{aligned}
$$

Ces $=7.112 \cdot 10^{7} \quad$ Capital Cost of Storage Building for Operating NPPs

$$
\begin{aligned}
& \text { Cdecoms }=\left\{\text { DC } \cdot \text { Cmf } 25.469 \cdot(1+\mathrm{Ia})^{8}\right\rfloor+\left[0.47 \cdot \mathrm{DS} \cdot \mathrm{Cmf} \cdot 2.745 \cdot(1+\mathrm{Ia})^{8}\right] \ldots \\
& +0.53 \cdot \mathrm{DS} \cdot \mathrm{Cmf} \cdot 25.469 \cdot(\mathrm{l}+\mathrm{Ia})^{8}+\mathrm{DE} \cdot \mathrm{Cmf} \cdot 25.469 \cdot(\mathrm{l}+\mathrm{Ia})^{8} \ldots \\
& +\left[0.47 \cdot \mathrm{DOs} \cdot \mathrm{Cmf} \cdot 2.745 \cdot(1+\mathrm{Ia})^{8}\right\}+\left[0.53 \cdot \mathrm{DOs} \cdot \mathrm{Cmf} \cdot 25.469 \cdot(1-\mathrm{la})^{8}\right.
\end{aligned}
$$

Cdecoms $=7.376 \cdot 10^{7} \quad$ Capital Costs of Storage Building for Decommissioning Waste from 3 RBMKs

Option 1 tolal present worh (in terms of lowest and highest estimated costs) to be used for option comparison

$$
\begin{aligned}
& \text { PWClL }=\mathrm{ClcL}+\mathrm{PWClp}+\mathrm{Cls}+\mathrm{CccL}+\mathrm{PWCcp}+\mathrm{Ccs}+\mathrm{Cdecoms} \\
& \text { PWClL }=5.824 \cdot 10^{8} \quad \text { Low Range of Present Worth for Option } 1 \\
& \text { PWClH }=\mathrm{ClcH}+\mathrm{PWClp}+\mathrm{Cls}+\mathrm{CccH}+\mathrm{PWCcp}+\mathrm{Ccs}+\text { Cdecoms } \\
& \text { PWCIH }=6.271 \cdot 10^{8} \quad \text { High Range of Present Worth for Option } 1
\end{aligned}
$$

Option 2:

Mobilc skid mounted process/evaporator units located at each site with a smaller cenural solidification and compactor faciliry to handle the reduced volume of concenurates.

The capacity of process/evaporator units varies and will have to be sized to accept the actual feed flows, but for purposes of this anaiysis process rates consistent with industry experience will be assumed to be in the range of 3 to 5 $\mathrm{m}^{\wedge} 3 / \mathrm{hr}$. For this analvsis it will be assumed that $20 \%$ of the unprocessed liquids are processed through the evaporators. the remaining are processed through filters, demins and monitor tanks. The number of evaporators required to handle $20 \%$ of the total unprocessed liquids from all of the Ukraunan NPPs is estumated as follows:

EvapRate $=3 \cdot 18 \quad$ Evaporator process rate $\mathrm{m}^{\wedge} 3 /$ day assuming 18 hours of operation per day

NFvap $-\frac{0.20 \cdot \text { TUL }}{\text { EvapRate }}$

NEvap $=8.426$ The estimated number of evapotators is between 5 (at $5 \mathrm{~m}^{\wedge} 3 / \mathrm{hr}$ ) and 9 (at $\left.3 \mathrm{~m}^{\wedge} 3 / \mathrm{hr}\right)$

Initial capital cost (low and high) for 3 skid mounted advanced volume reduction uains located at the Ukrainian NPP sites (ail sites have operational evaporators).
C2cI. $-3 \cdot 4000000 \cdot(1+\mathrm{Ia})^{8}$
$\mathrm{C} 2 \mathrm{cL}=1.773 \cdot 10^{7}$
$\mathrm{C} 2 \mathrm{cH}-3.9000000 \cdot(l+\mathrm{Ia})^{8}$
$\mathrm{C} 2 \mathrm{cH}=3.989 \cdot 10^{7}$ 
This option must also include the capical cost of a smallet cenuralized solidification system. The volume reduction factors for typical process/evaporation systems will be used to factor down the capital costs for a smaller centralized solidification system.

$\mathrm{F} 2=\frac{\operatorname{TEB} \cdot \frac{1}{6 \cdot 6}+\pi \mathrm{LR} \cdot \frac{1}{2}+\operatorname{THR} \cdot \frac{1}{2}}{\mathrm{PRI}}$

$F 2=1.501$

Initial Capital Costs (Low and High) in Present Dollars for a smaller Solidification System

$\begin{array}{ll}\mathrm{C} 2 \mathrm{ScL}=\mathrm{F} 2 \cdot 500000 \cdot(1+\mathrm{Ia})^{14} & \mathrm{C} 2 \mathrm{ScL}=1485796.297 \\ \mathrm{C} 2 \mathrm{ScH}=\mathrm{F} 2 \cdot 3000000 \cdot(1+\mathrm{Ia})^{14} & \mathrm{C} 2 \mathrm{ScH}=8914777.78\end{array}$

Annual Processing Costs Given in Yearly Costs and Converted to Total Present Costs for $n$ years of Operation. Consistent with Ref. [11] the processing and storage costs for this option include the costs for the solidification rains.

AC2p - TEB C Cmf $\left.14.075 \cdot(1+\mathrm{Ia})^{8}\right]+(\mathrm{TLR}+\mathrm{THR}) \cdot\left[\mathrm{Cmf} \cdot 29.093 \cdot(1+\mathrm{la})^{8}\right]$

AC2p $=4425203.779 \quad$ Yearly Processing Cost

$\mathrm{PWC} 2 \mathrm{P}=\mathrm{PA} \cdot \mathrm{AC} 2 \mathrm{p}$

$\mathrm{PWC2} \mathrm{p}=5.515 \cdot 10^{7} \quad$ Present Worth of yearly processing costs over n years of operation

Capital costs for storage building space for the reduced volumes from the smaller solidification systern

$\mathrm{C} 2 \mathrm{~s}=\operatorname{TEB} \cdot \mathrm{n} \cdot \mathrm{Cmf} \cdot 1.092 \cdot(1+\mathrm{la})^{8}:+(\mathrm{TLR} \cdot \mathrm{THR}) \cdot \mathrm{n} \cdot \mathrm{Cmf} \cdot 2.857 \cdot(\mathrm{l}+\mathrm{Ja})^{8}$

$C 2 s=7090777.938 \quad$ Capical Cost for Storage Building Space

Option 2 total present worh (in terms of lowest and highest estimated costs) to be used for option comparison:

PWC2I - C2cl- C2SeL $+\mathrm{PWC} 2 \mathrm{p}+\mathrm{C} 2 \mathrm{~s}+\mathrm{CccL}+\mathrm{PWCcp}-\mathrm{C} c \mathrm{C} \cdot \mathrm{Cdecoms}$

PWC2L $=4.465 \cdot 10^{8} \quad$ Low Range of Present Worh for Option 2

PWC2H $=\mathrm{C} 2 \mathrm{cII}-\mathrm{C} 2 \mathrm{ScH}-\mathrm{PWC} 2 \mathrm{p}+\mathrm{C} 2 \mathrm{~s}-\mathrm{CccH}+\mathrm{PWCep}-\mathrm{C} c \mathrm{C}+\mathrm{Cdecoms}$

PWC2H $=4.781 \cdot 10^{8} \quad$ High Range of Present Worh for Option 2 
Option 3:

Incineration System

Because of the high cost of incineration systems due to the high initial capital costs and the high costs of operation. including scrubbing and filtering the exhaust gases, only the capital costs are evaluated. Incineration systems although commercially available are not routinely used at commercial nuclear reactors and their use for the Ukrainian nuclear reactors is not recommended because of the high costs involved. In addition, higher specific activity resulis which increases the cost of processing and storage.

The capital costs (low and high) for an incineration svstem are factored up to handle the total combustible waste. The factor is based on an assumed incinerator capacicy of $70 \mathrm{~kg} / \mathrm{hr}$ processing $1300 \mathrm{~m}^{\wedge} 3 / \mathrm{yr}$ of the total solids (assuming $80 \%$ are combustible), all of the low-level resins, and the Chemobyl decommissioning combustible waste:

IncinRate $=1300$

$\mathrm{Fi}=\frac{0.80 \cdot \mathrm{TSG}+\mathrm{TLR}+\frac{0.8 \cdot \mathrm{DOs}}{20}+\frac{0.80 \cdot \mathrm{DS}}{20}}{}$

$F i=3.24]$

$\mathrm{C} 3 \mathrm{cL}-\mathrm{Fi} \cdot 2.0 \cdot 10^{6} \cdot(\mathrm{I}+\mathrm{Ia})^{14} \quad \mathrm{C} 3 \mathrm{cL}=1.283 \cdot 10^{7}$

$\mathrm{C} 3 \mathrm{cH}=\mathrm{Fi} \cdot 24 \cdot 10^{6} \cdot(1+1 \mathrm{a})^{8} \quad \mathrm{C} 3 \mathrm{cH}=1.149 \cdot 10^{8}$ 


\section{Appendix B: Figures Showing Typical Treatment Methods and Processes}




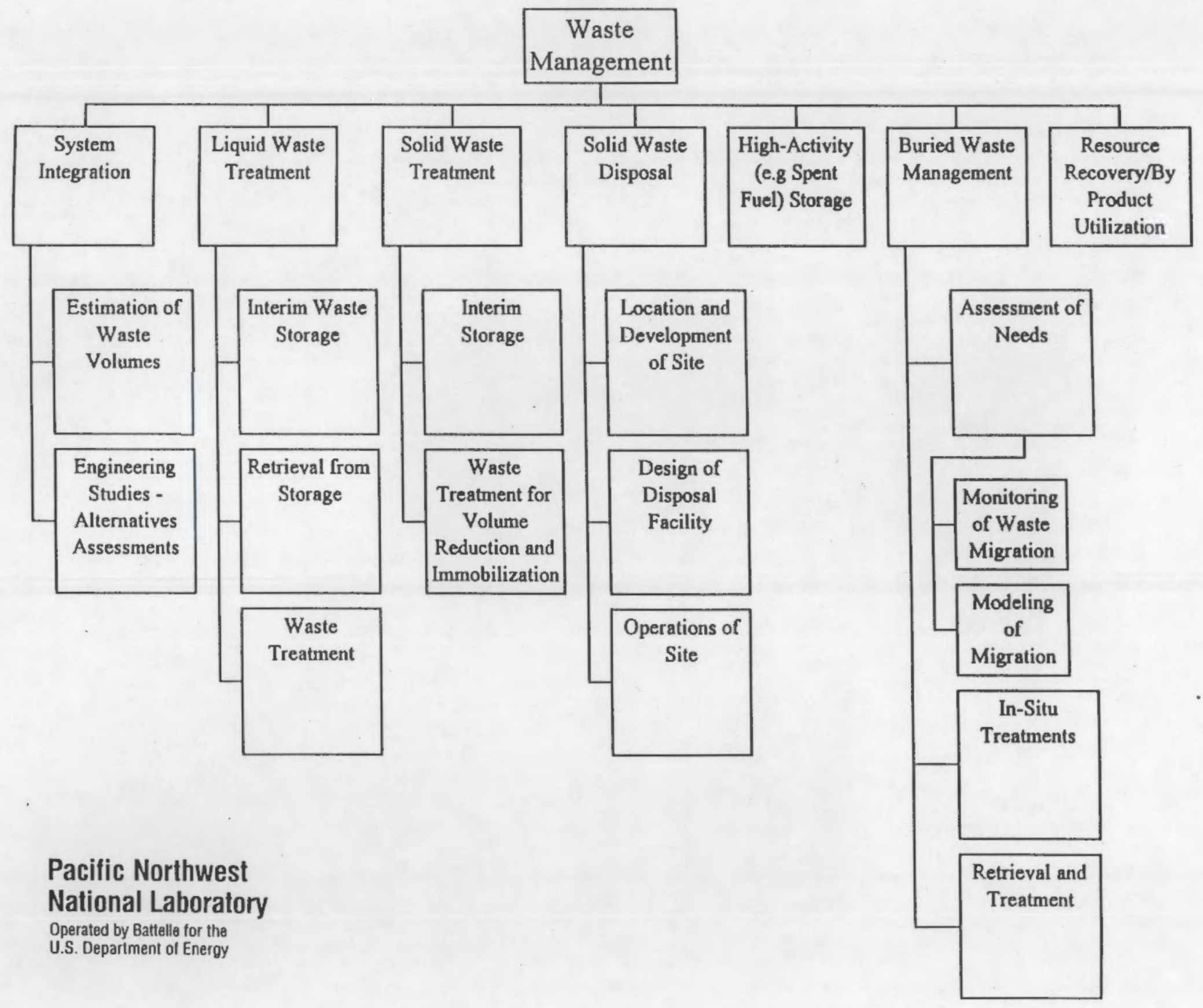




\section{Process Flow}

WET WASTES

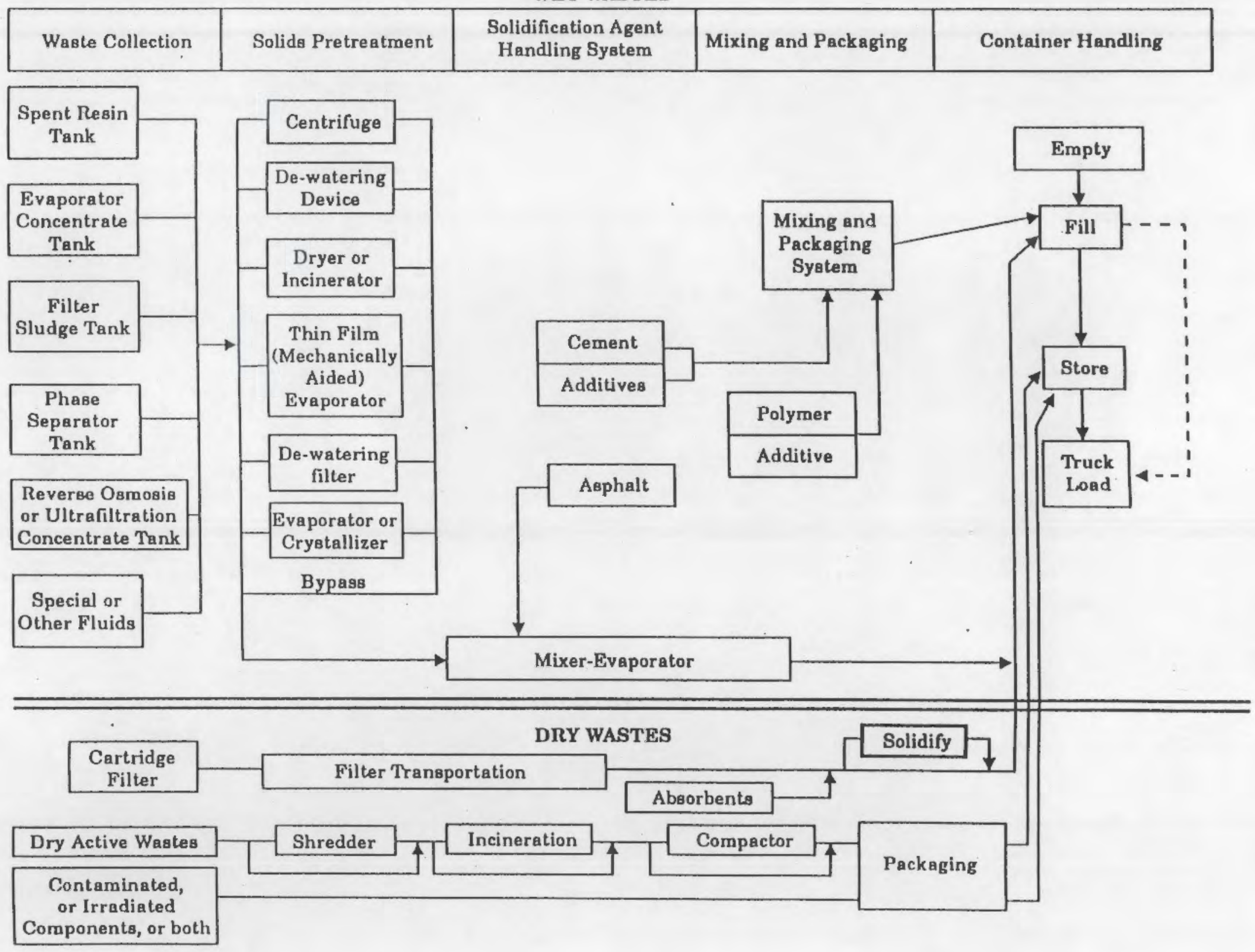




\section{Basic PWR Liquid Radioactive Waste Processing Diagram}

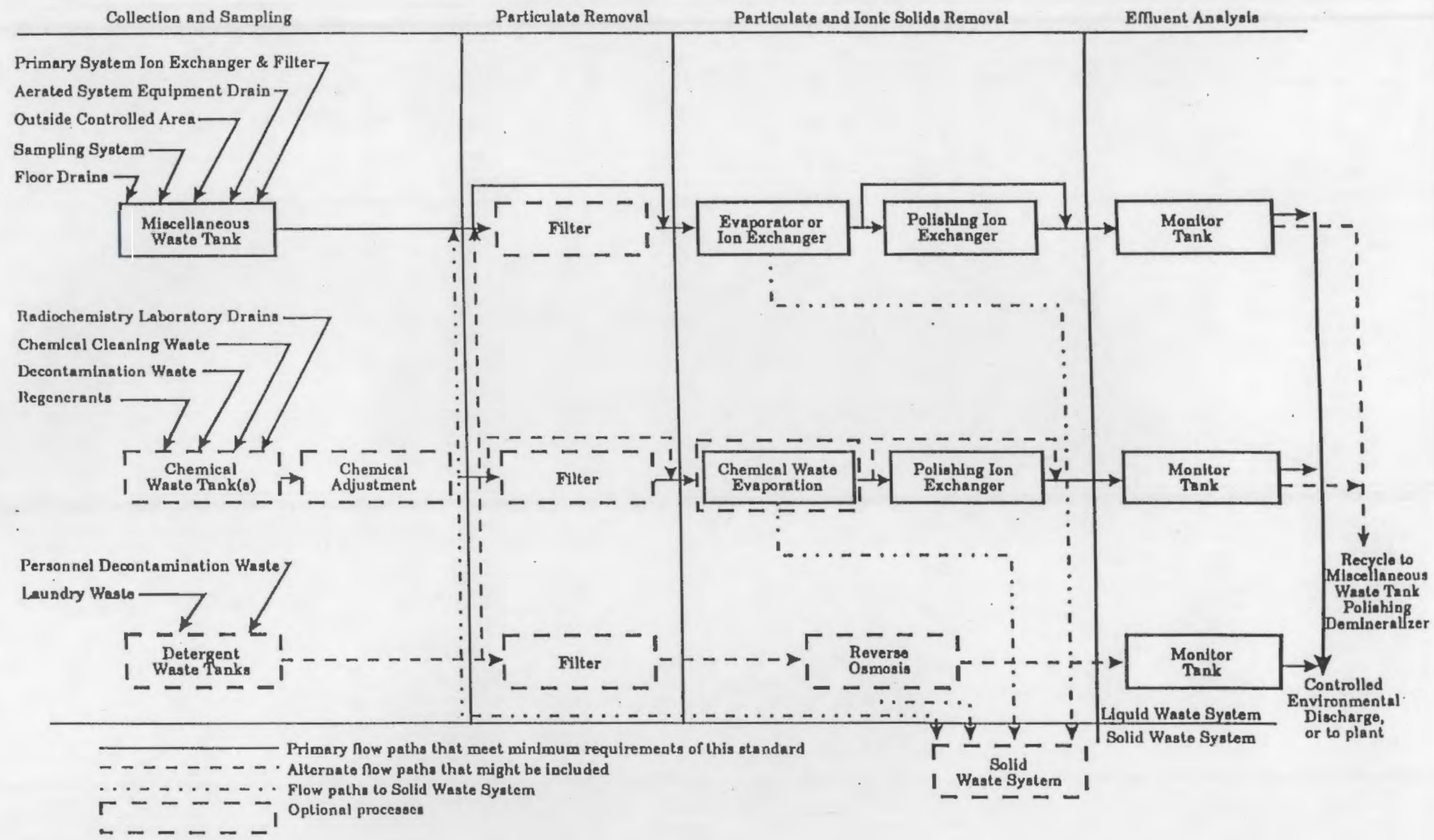


Basic BWR Liquid Radionctive Waste Processing Dingram

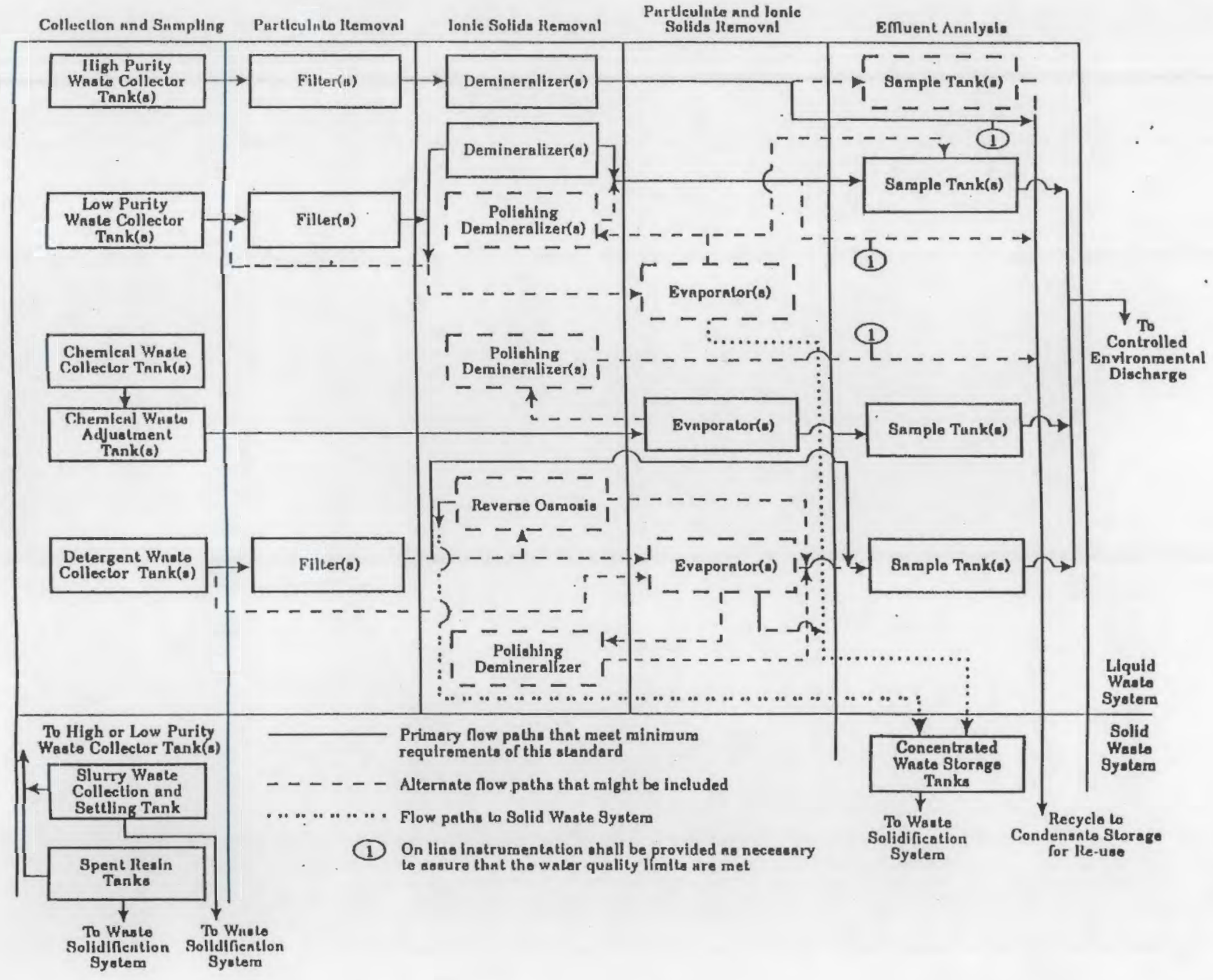


RADIOACTIVE WASTE TECHNOLOGY

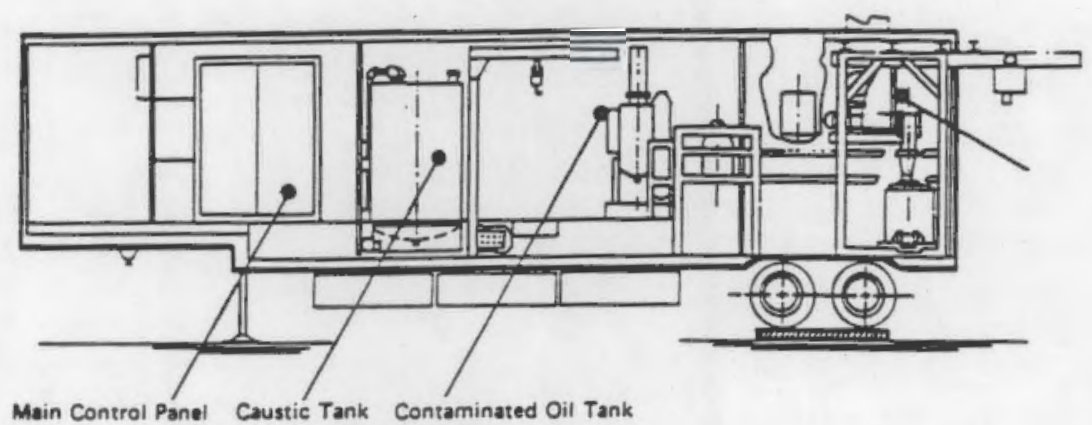

Operations Trailer
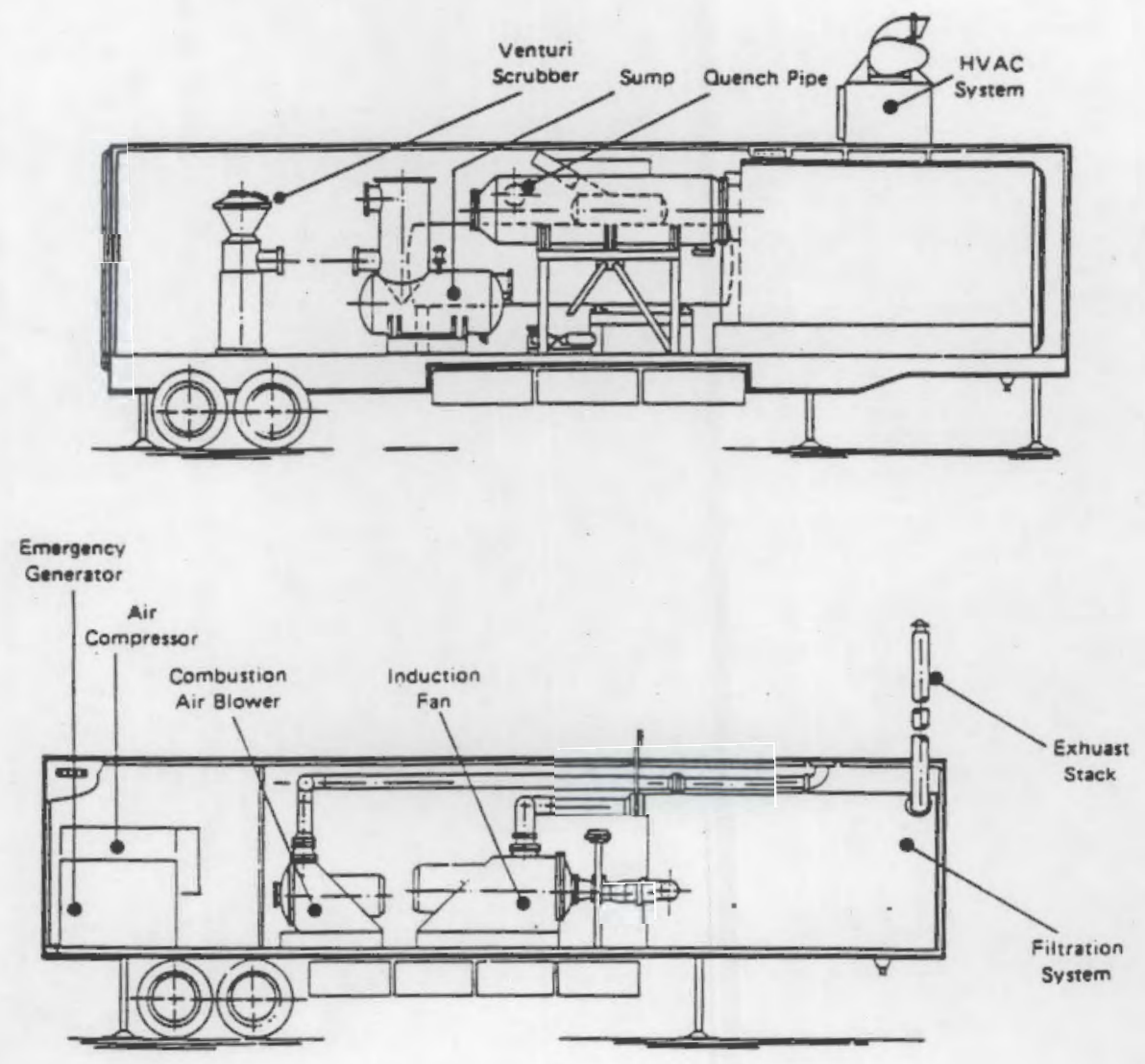


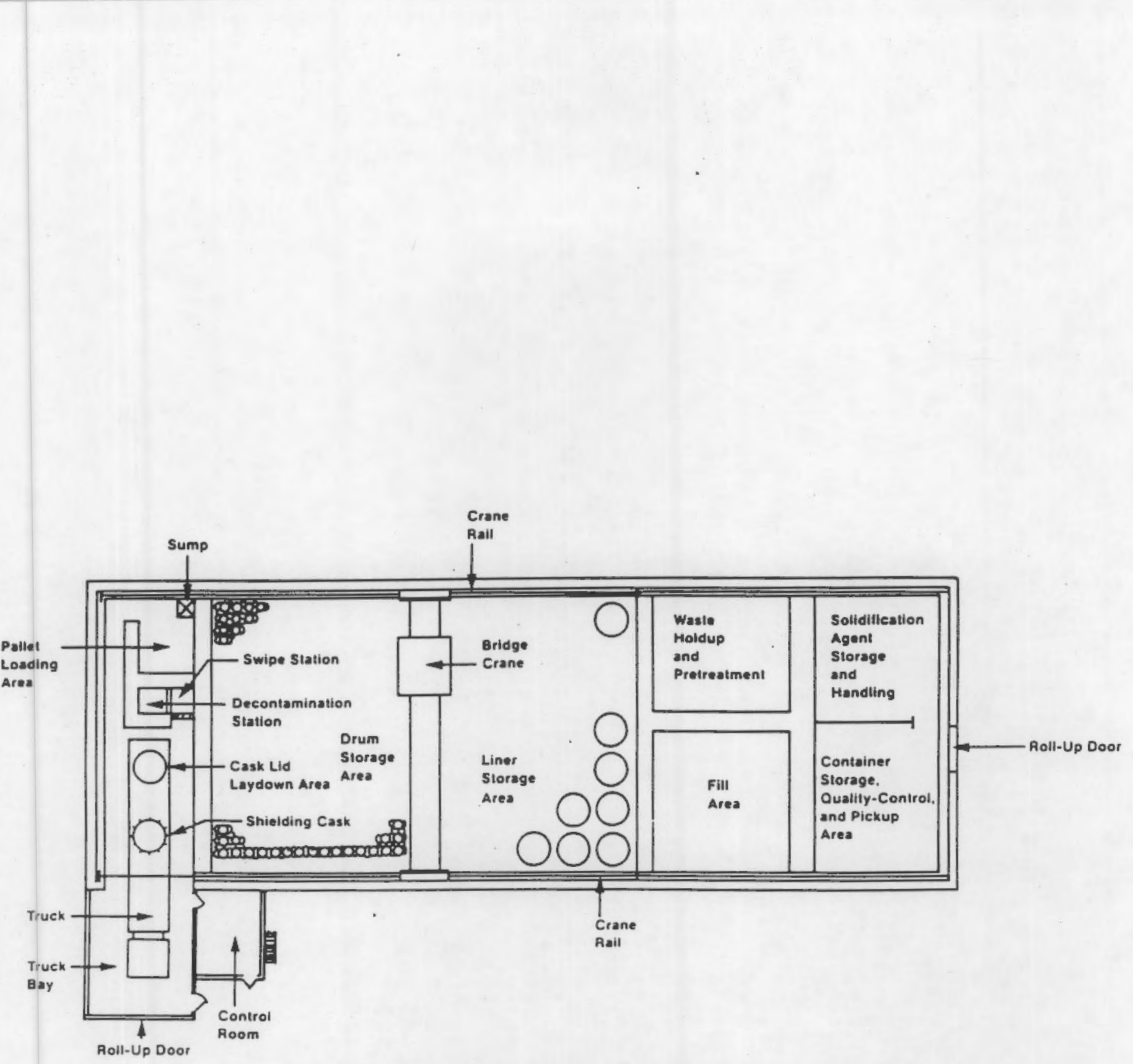

ARRANGEMENT OF A TYPICAL. RADIOACTIVE WASTE SOLIDIFICATION AND CONTAINER HANDLING AND STORAGE FACILITY (Courtesy of Electric Power Research Institute.) 


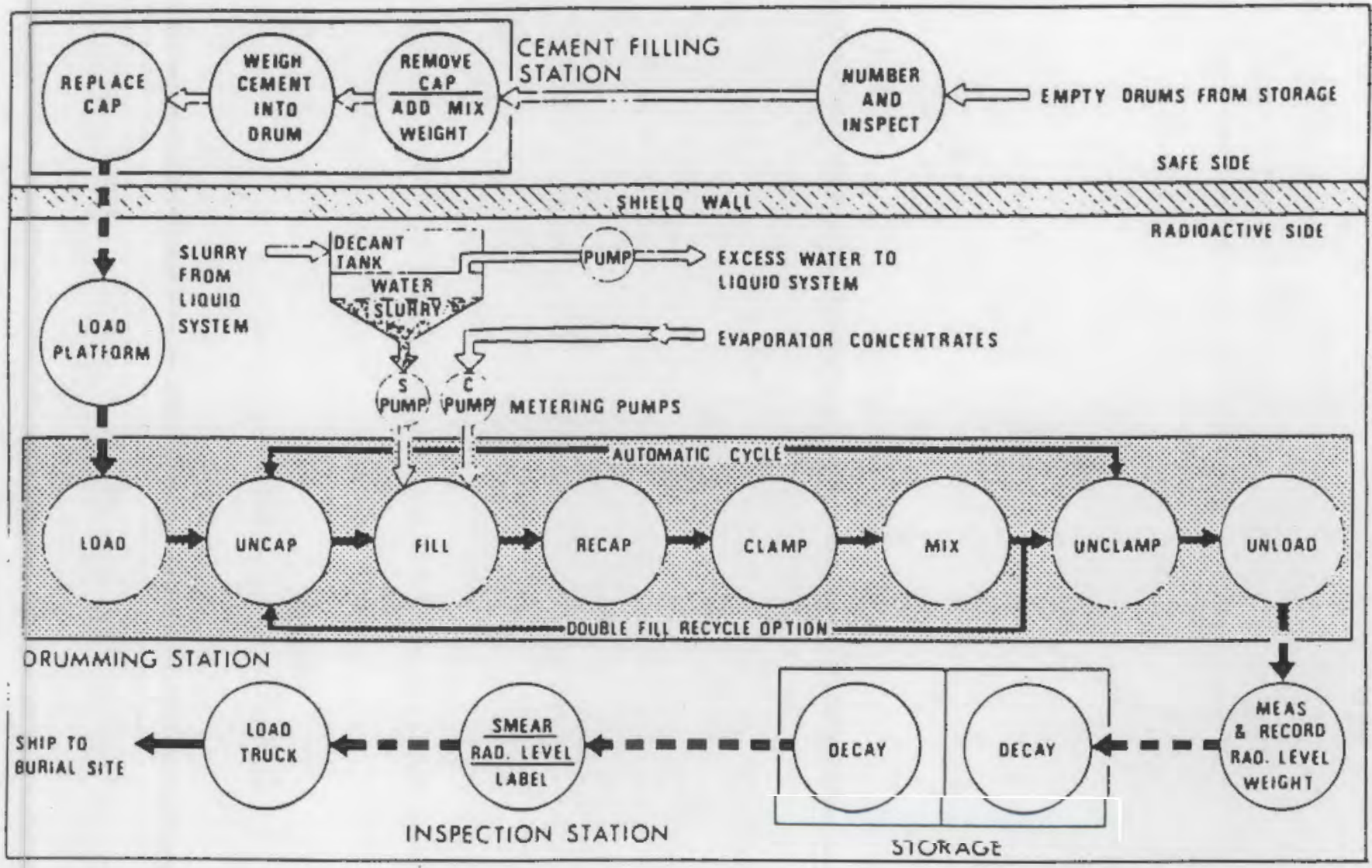

SIMPLIFIED PROCESS FLOW DIAGRAM FOR AN IN-DRUM

TUMBLING CEMENT RADIOACTIVE WASTE SOLIDIFICATION SYSTEM

(Adapted from Stock Equipment Co. Literature.) (Courtesy of Stock

Equipment Co.) 


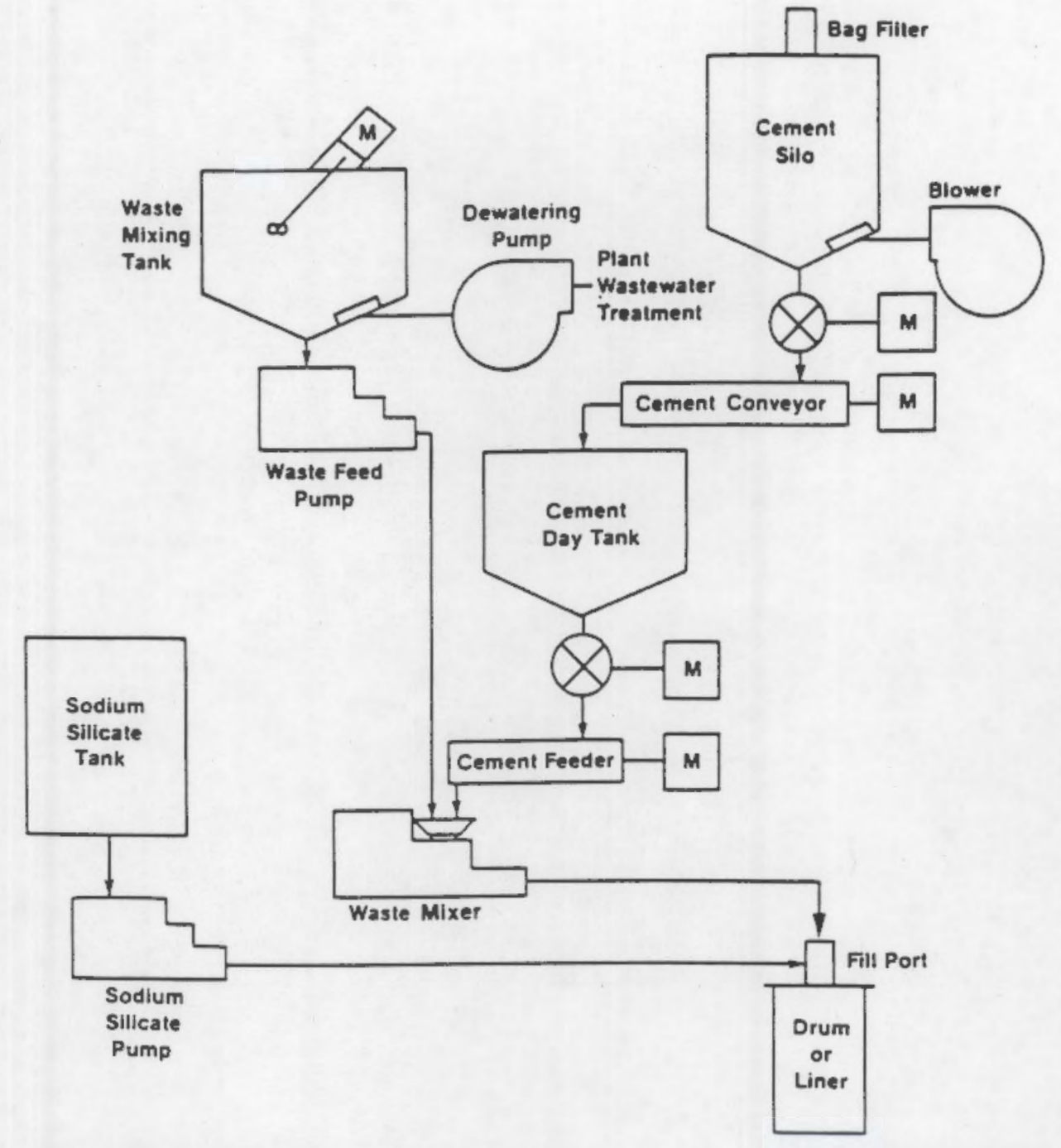

SIMPLIFIED PROCESS FLOW DIAGRAM FOR AN IN-LINE CEMENT / SODIUM SILICATE RADIOACTIVE WASTE SOLIDIFICATION SYSTEM

(Courtesy of Electric Power Research Institute.) 


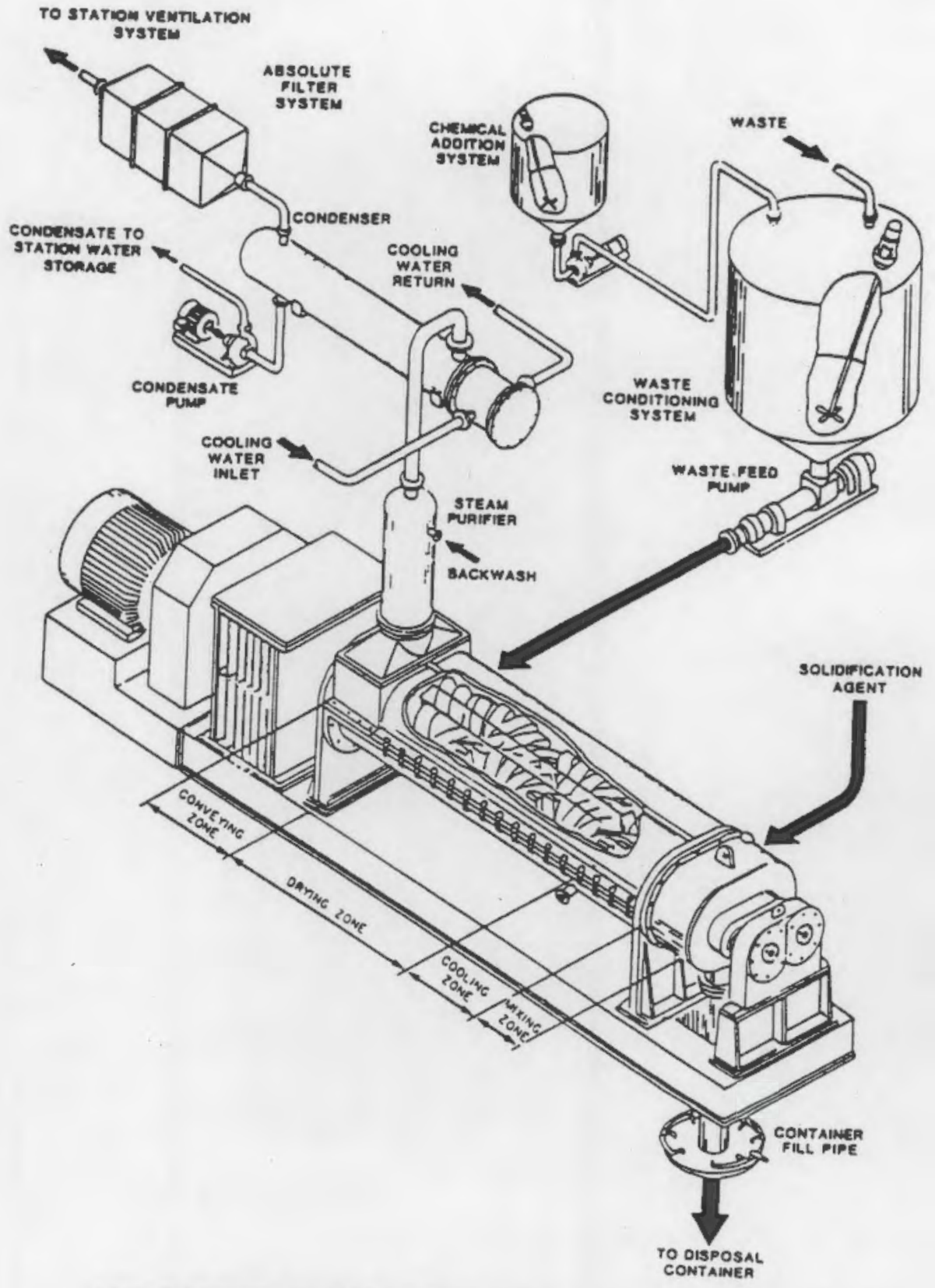

MIXER / DRYER RADIOACTIVE WASTE SOLIDIFICATION SYSTEM (Adapted from ATCOR Engineered Systems Literature.)

(Courtesy of ATCOR Engineered Systems.) 


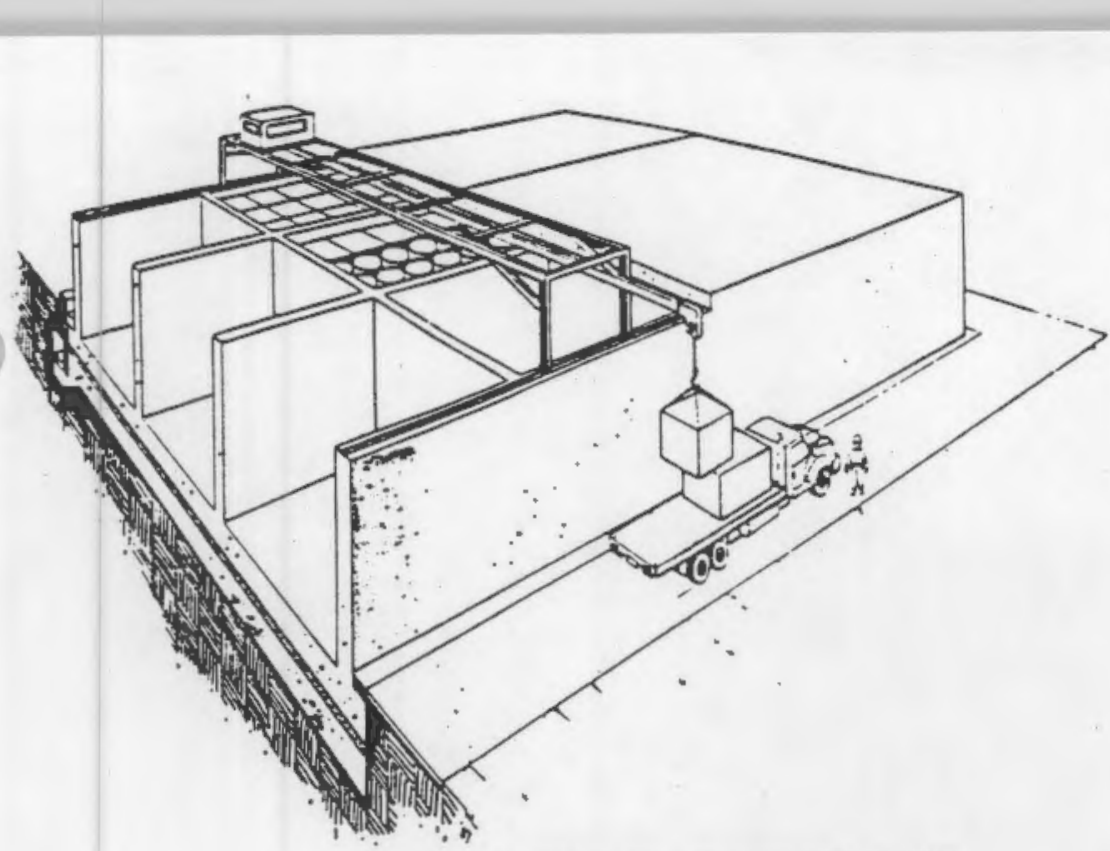

Schematic of AGV facility. Source: (DOE 1987).
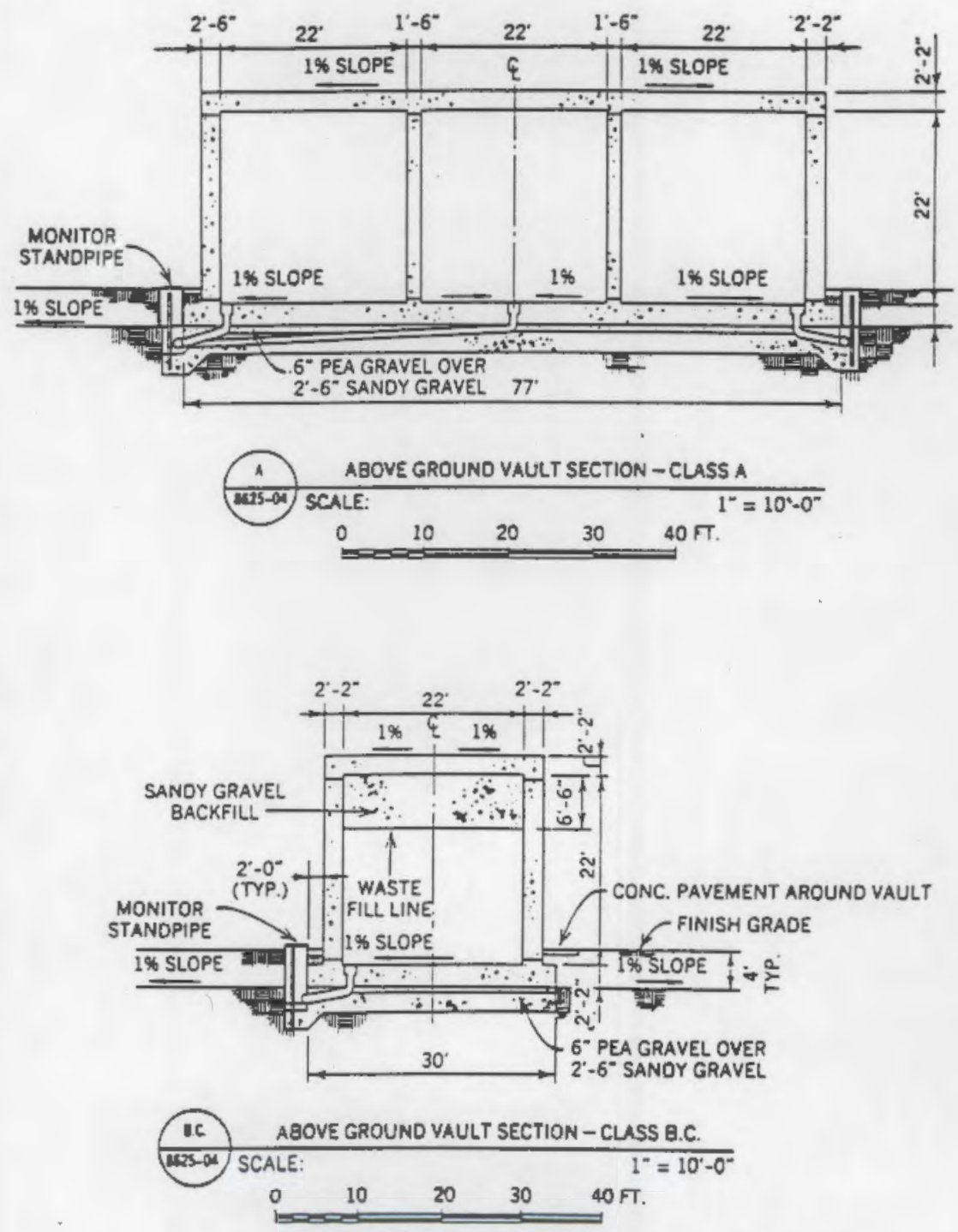

Cross sections of AGV structures. Source: (DOE 1987). 


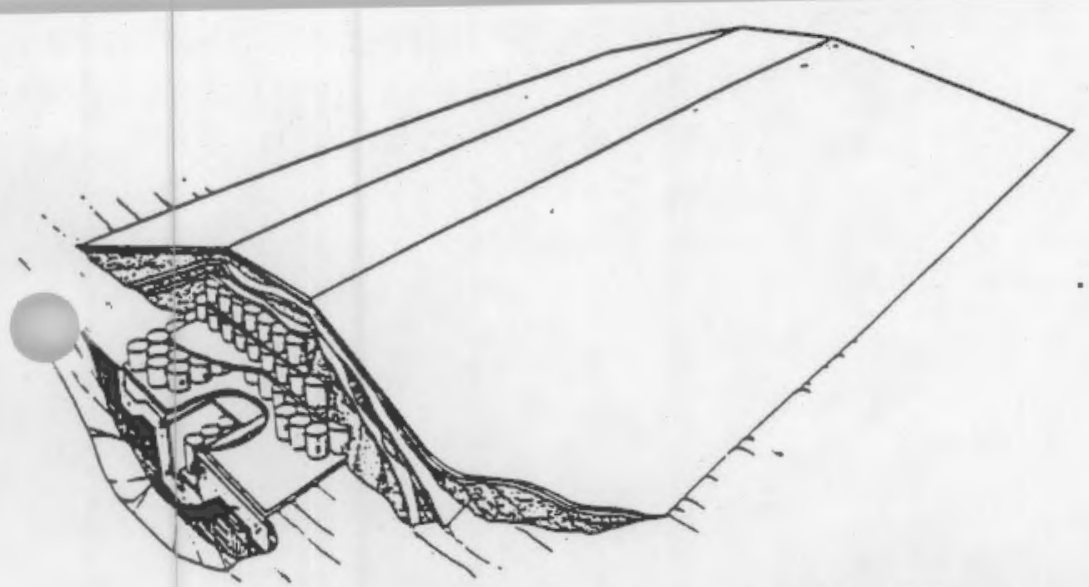

Schematic of EMCB facility. Source: (DOE 1987).

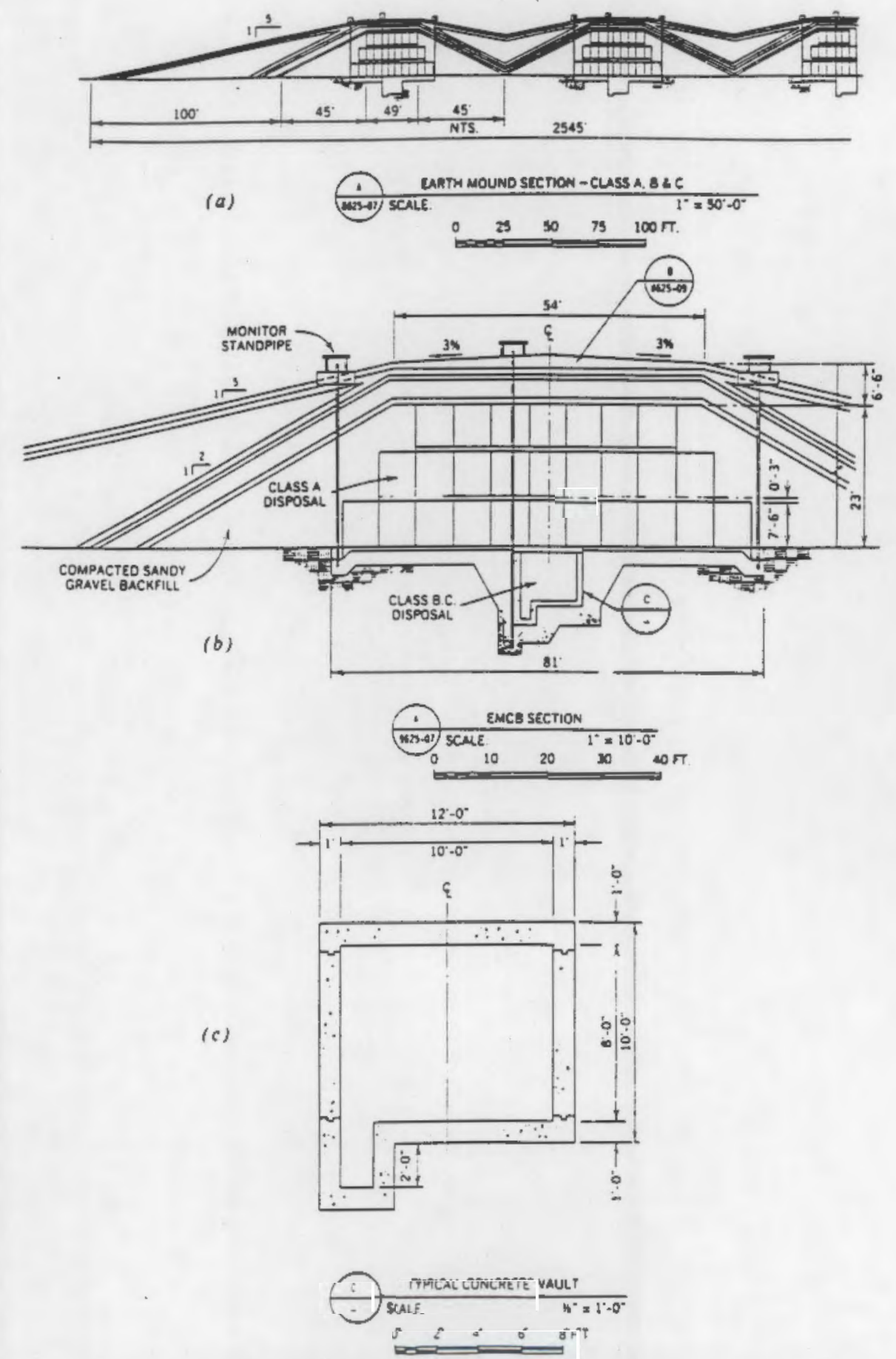

Cross section of colocated EMCB tumulus and monolith. (a) Overall layout; (b) tumulus detail; (c) concrete detail. Source: (DOE 1987). 


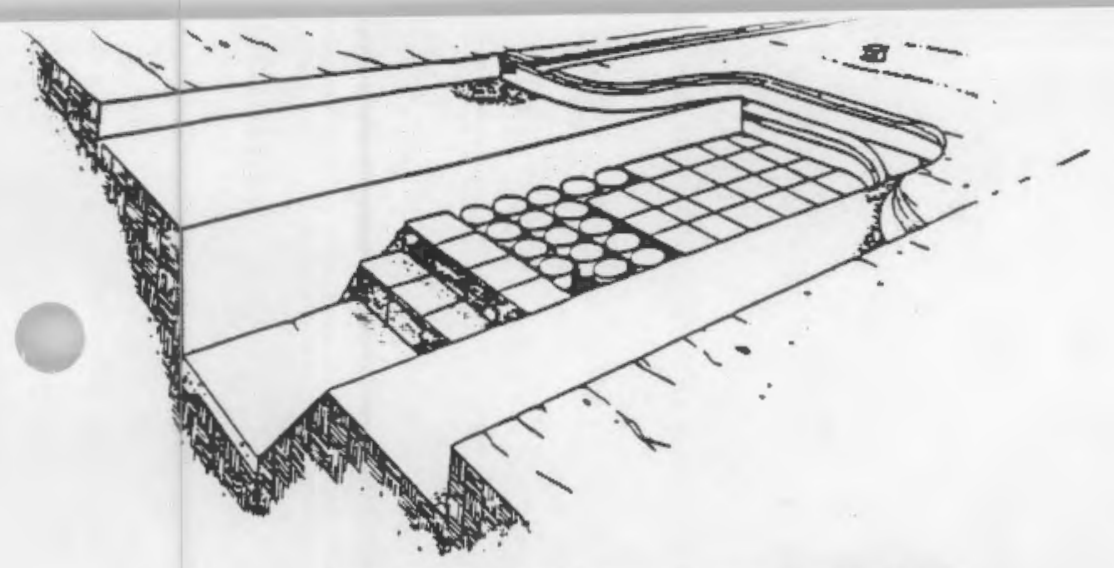

Schematic of SLD facility. Source: (DOE 1987).
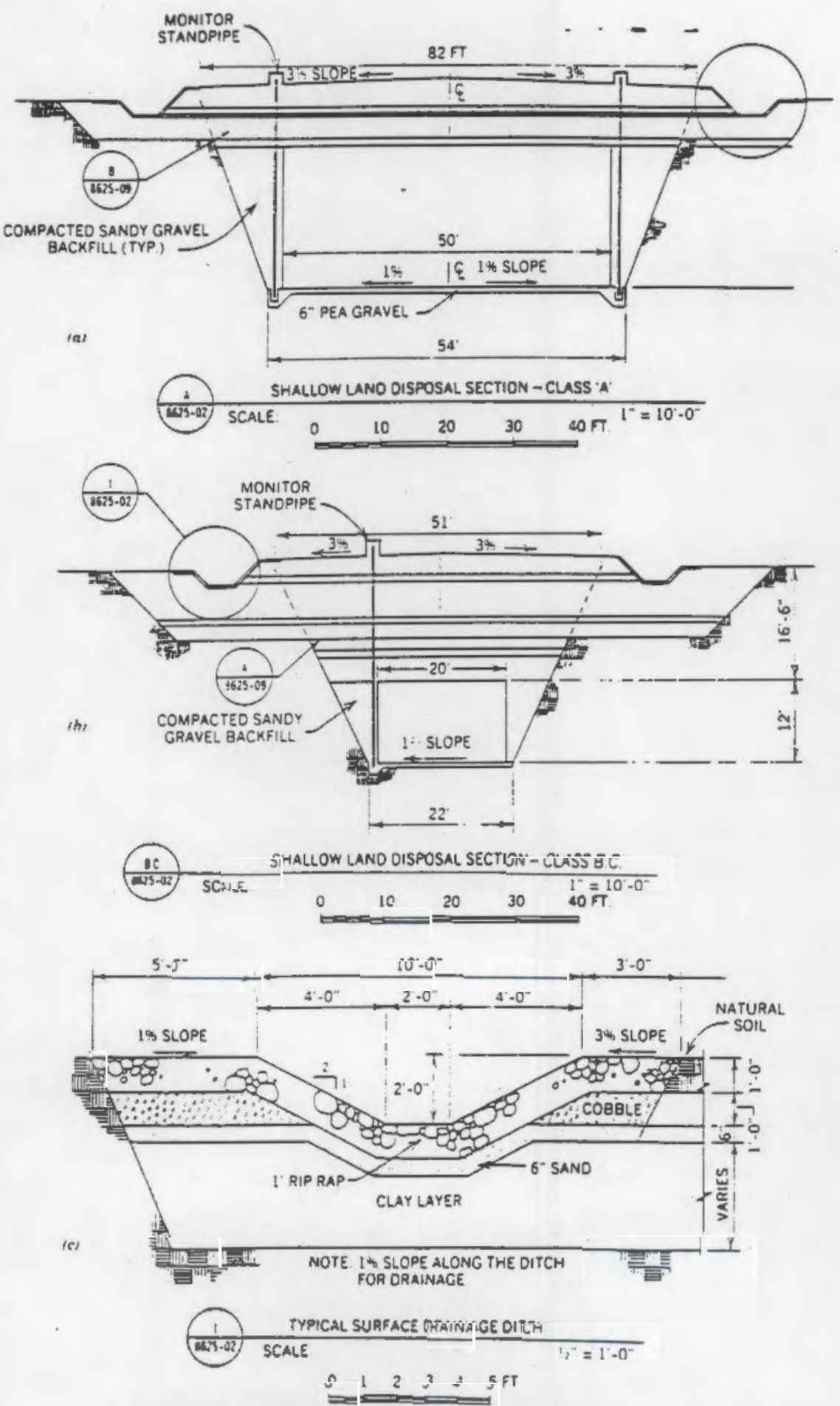

Cross sections of SLD trenches. (a) Class A waste trench: (b) segregated class B-C waste trench: (c) surface drainage ditch details. Source: (DOE 1987). 


\section{Appendix C: Classification of Radioactive Waste in the Former USSR}

Categories of radioactive waste for the former USSR are as follows:

Type

Liquids:
Low-Level
$<1 \times 10^{-5} \mathrm{Ci} / 1$
Intermediate-Level
High-Level
$21 \times 10^{-5} \mathrm{Ci} / 1$
$\geq 1 \mathrm{Ci} / 1$

Solid Wastes Based on Dose Rate, $10 \mathrm{~cm}$ from Surface ${ }^{(2 \mathrm{sed})}$.
Low-Level
$0.1-30 \mathrm{mr} / \mathrm{hr}$
Medium-Level
$30-300 \mathrm{mr} / \mathrm{hr}$
Intermediate-Level
$0.3-1 \mathrm{r} / \mathrm{hr}$
High-Level
$21 \mathrm{r} / \mathrm{hr}$

Solid Waste Classification Based Upon Activity ${ }^{(b)}$.

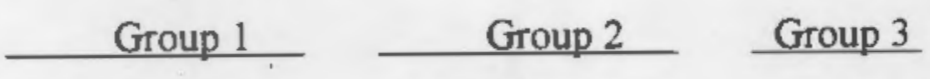

Beta Activity, $\mathrm{Ci} / \mathrm{kg}$

Alpha Activity, $\mathrm{Ci} / \mathrm{kg}$

$$
\begin{array}{lll}
2 \times 10^{-6}-1 \times 10^{-4} & 1 \times 10^{-4}-1 \times 10^{-1} & >1 \times 10^{-1} \\
2 \times 10^{-7}-1 \times 10^{-5} & 1 \times 10^{-5}-1 \times 10^{-2} & >1 \times 10^{-2}
\end{array}
$$

Gaseous Waste Classifications ${ }^{(\mathrm{c})}$ :
Low-Level
$\leq 3.7 \times 10^{-3} \mathrm{~Bq} / \mathrm{l}$
$\left(1 \times 10^{-13} \mathrm{Ci} / 1\right)$
Intermediate-Level
$>3.7 \times 10^{-3} \leq 370 \mathrm{~Bq} / 1$
$\left(>1 \times 10^{-13} \leq 1 \times 10^{-8} \mathrm{Ci} / \mathrm{l}\right)$
High-Level
$>370 \mathrm{~Bq} / \mathrm{l}$
$\left(>1 \times 10^{-8} \mathrm{Ci} / \mathrm{l}\right)$

(a) National Academy of Sciences (1990), Bukharin 1991.

(b) Bukharin 1991.

(c) Mosinets (1991) (based on Sanitary Rules for Radioactive Waste Management, SPORO85).

(d) Egorov NN, et al, 1994. IAEA-CN-59/50

NOTE: Solid wastes below $\mu \mathrm{r} / \mathrm{hr}$ are not considered radioactive and do not require any special treatment or handling. $1 \mathrm{Ci}=37 \mathrm{GBq} \quad 1 \mathrm{R}=258 \mu \mathrm{Ci} / \mathrm{kg}$ 


\title{
Appendix D: Questions Submitted to GOSKOMATOM Regarding the Proposed Facility
}

\author{
Questions on the Details of the Ukrainian Proposal to Build \\ a Central Radwaste Processing Facility
}

1. What documentation has been prepared to date describing the proposed central radioactive waste processing facility?

2. What are the Ukrainian licensing requirements for such a facility?

3. Is the transport of liquid radwaste from a VVER plant to the proposed central facility required? What method is proposed for shipment of the liquid radwastes? Do the VVERs have operational evaporators and supporting filters and demineralizes?

4. For each plant type VVER-1000, VVER-440, and RBMK-1000 the following information is needed:

a. How is the liquid radwaste categorized, e.g. high-level, low-level, clean, dirty, primary, secondary, evaporator concentrates, demineralizer resin discharges?

b. For each category, what is the annual volume of liquid radwaste produced in gal (1)?

c. For each category, what is the generation rate of liquid radwaste produced in $\mathrm{gal} / \mathrm{min}(\mathrm{V} / \mathrm{sec})$ (for demineralizer resin discharges in $\mathrm{f}^{3} / \mathrm{yr}\left(\mathrm{m}^{3} / \mathrm{yr}\right)$ )?

d. What are available storage tank capacities in gal (l).

e. How many evaporators in each plant and what are their capacities in $\mathrm{gal} / \mathrm{min}$ $(\mathrm{l} / \mathrm{sec})$ ? Are they operational?

f. For low-level liquid wastes processed without evaporators through filters and mixed bed demineralizes what is the capacity in $\mathrm{gal} / \mathrm{min}(\mathrm{l} / \mathrm{sec})$ ?

g. How is the solid radwaste categorized, e.g. high-level, low-level, filter cartridges, resins?

h. For each category, what is the annual volume of solid radwaste produced in $\mathrm{ft}^{3}$ $\left(\mathrm{m}^{3}\right)$ ? 
i. For each category, what is the generation rate of solid radwaste produced in $\mathrm{ft}^{3} / \mathrm{yr}$ $\left(\mathrm{m}^{3} / \mathrm{yr}\right)$ ?

j. What is the available storage space for solid radwastes in $\mathrm{yd}^{3}\left(\mathrm{~m}^{3}\right)$ or building size?

k. How is the solid radwaste packaged e.g. 55gal drums, shipping boxes etc? Is compaction used?

5. For the proposed central processing facility, what are the design processing capacities for both liquids and solids and the proposed storage space?

a. How many radwaste processing trains will the facility have? If more than one, what are the individual process train capacities in $\mathrm{gal} / \mathrm{min}(\mathrm{V} / \mathrm{sec})$ or $\mathrm{ft}^{3} / \mathrm{hr}\left(\mathrm{m}^{3} / \mathrm{hr}\right)$ ?

b. How many evaporators will be used and what are the individual capacities gal $/ \mathrm{min}$ $(1 / \mathrm{sec})$ ? What are the evaporator decontamination factors?

c. How many mix-bed and or cation demineralizes are proposed? What are their resin volumes $\mathrm{ft}^{3}\left(\mathrm{~m}^{3}\right)$ and total volumes $\mathrm{ft}^{3}\left(\mathrm{~m}^{3}\right)$ ? What are the demineralizer decontamination factors?

d. How many filters are proposed and what are their capacities $\mathrm{gal} / \mathrm{min}(1 / \mathrm{sec})$ and filter sizes in microns?

e. Have charcoal absorbers been incorporated to address any organic (oil contaminates) material in the liquid waste stream?

d. For the liquid processing trains, has an off gas and cover gas system been incorporated in the design?

e. Has a solidification process been established (e.g. cement, grout etc.)? If so, what is the proposed solidification train capacity drums $/ \mathrm{hr}$ or $\mathrm{m}^{3} / \mathrm{hr}$ ?

f. What is the proposed monitor tank (evaporator condenser distillates) storage capacity gal (l)?

g What is the proposed solid waste storage area capacity $\mathrm{yd}^{3}\left(\mathrm{~m}^{3}\right)$ or building sizes?

6. What are the Ukrainian limitations for effluent releases and the isotopic inventory in terms of $\mathrm{Ci} / \mathrm{yr}$ or concentration $\mathrm{Ci} / \mathrm{gm}$ for the individual plants and for the proposed processing facility?

Technical Evaluation of Proposed Ukrainian Radioactive Waste Processing Facility

D.2 
7. Has a source term evaluation been completed to identify the activity of the radwaste to be processed?

8. Have specialized material concerns been considered? This would include such items as precluding corrosive attack through the use of Inconel 625 on evaporator components in contact with the evaporator concentrates, etc.

9. What type of in-line monitoring and analysis systems are proposed for the central processing facility?

10. The GOSKOMATOM letter requesting support from DOE indicated an estimated cost of US $\$ 40$ million with half of the cost being capital equipment. Please provide details on the cost assumptions that went into this estimate. For example, per unit costs in terms of dollars per $\mathrm{m}^{3}$ of waste processed, capital equipment cost estimates, design, engineering and construction labor cost estimates, and operations and maintenance cost estimates.

11. What are the types and volumes of radwaste estimated to be generated from the decommissioning of the Chernobyl NPP that will be processed in the central facility. 